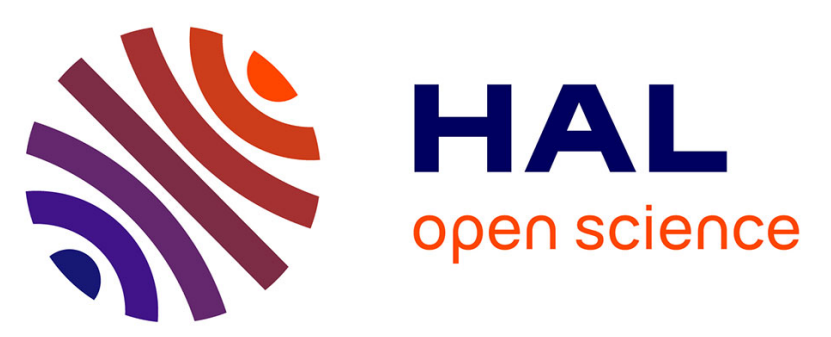

\title{
A thermodynamic model of aqueous electrolyte solution behavior and solid-liquid equilibrium in the Li-H-Na-K-Cl-OH-H2O system to very high concentrations (40 molal) and from 0 to $250 \mathrm{C}$
}

Arnault Lassin, Christomir Christov, Laurent André, Mohamed Azaroual

\section{To cite this version:}

Arnault Lassin, Christomir Christov, Laurent André, Mohamed Azaroual. A thermodynamic model of aqueous electrolyte solution behavior and solid-liquid equilibrium in the Li-H-Na-K-Cl-OH-H2O system to very high concentrations (40 molal) and from 0 to 250 C. American journal of science, 2015, 815 (8), pp.204-256. 10.2475/03.2015.02 . hal-01331967

\section{HAL Id: hal-01331967 https: / hal-brgm.archives-ouvertes.fr/hal-01331967}

Submitted on 15 Jun 2016

HAL is a multi-disciplinary open access archive for the deposit and dissemination of scientific research documents, whether they are published or not. The documents may come from teaching and research institutions in France or abroad, or from public or private research centers.
L'archive ouverte pluridisciplinaire HAL, est destinée au dépôt et à la diffusion de documents scientifiques de niveau recherche, publiés ou non, émanant des établissements d'enseignement et de recherche français ou étrangers, des laboratoires publics ou privés. 


\title{
A thermodynamic model of aqueous electrolyte solution behavior and solid- liquid equilibrium in the $\mathrm{Li}-\mathrm{H}-\mathrm{Na}-\mathrm{K}-\mathrm{Cl}-\mathrm{OH}-\mathrm{H}_{2} \mathrm{O}$ system to very high concentrations (40 molal) and from 0 to $250{ }^{\circ} \mathrm{C}$
}

\author{
Arnault Lassin $^{1} *$, Christomir Christov ${ }^{2,3}$, Laurent André $^{1}$, Mohamed Azaroual $^{1}$ \\ ${ }^{1}$ BRGM - 3 avenue C. Guillemin - Orléans, France (a.lassin@brgm.fr, 1.andre@brgm.fr, \\ m.azaroual@brgm.fr) \\ 2 GeoEco Consulting 2010, 13735 Paseo Cevera, San Diego, CA 92129, USA \\ (hristovi@ sbcglobal.net) \\ ${ }^{3}$ Institute of General and Inorganic Chemistry, Bulgarian Academy of Sciences, 1113 Sofia, \\ Bulgaria (christov@svr.igic.bas.bg)
}

* Corresponding author. E-mail: a.lassin@brgm.fr 
ABSTRACT: This paper describes a chemical model that calculates solute and solvent activities and solid-liquid equilibria in the $\mathrm{Li}-\mathrm{H}-\mathrm{Na}-\mathrm{K}-\mathrm{Cl}-\mathrm{OH}-\mathrm{H}_{2} \mathrm{O}$ system from dilute to high solution concentration within the 0 to $250^{\circ} \mathrm{C}$ temperature range. The model coherently extends to $\mathrm{Li}$ the temperature-variable $\mathrm{H}-\mathrm{Na}-\mathrm{K}-\mathrm{OH}-\mathrm{Cl}-\mathrm{H}_{2} \mathrm{O}$ model of Christov and Møller (Geochim. Cosmochim. Acta 68 (2004b), 1309). The solubility modeling approach based on Pitzer's specific interaction equations (J. Phys. Chem. 77 (1973), 268) is used. All binary $\left(\mathrm{LiCl}-\mathrm{H}_{2} \mathrm{O}\right.$ and $\left.\mathrm{LiOH}-\mathrm{H}_{2} \mathrm{O}\right)$ and ternary (LiCl-HCl-H $\mathrm{H}_{2} \mathrm{O}$, LiCl-NaCl-H $\mathrm{H}_{2} \mathrm{O}$, LiCl-KCl-H $\mathrm{H}_{2} \mathrm{O}$, $\mathrm{LiOH}-\mathrm{NaOH}-\mathrm{H}_{2} \mathrm{O}$, LiOH-KOH-H $\mathrm{H}_{2} \mathrm{O}$, and $\mathrm{LiOH}-\mathrm{LiCl}-\mathrm{H}_{2} \mathrm{O}$ ) lithium subsystems are included in the model parameterization. The model for the $\mathrm{LiCl}-\mathrm{H}_{2} \mathrm{O}$ system is parameterized using two different approaches: (1) with 4 ion interaction binary parameters $\left(\beta^{(0)}, \beta^{(1)}, \beta^{(2)}\right.$, and $\left.C^{\varphi}\right)$, and (2) with 3 ion interaction binary parameters $\left(\beta^{(0)}\right.$, $\beta^{(1)}$, and $\mathrm{C}^{\varphi}$ ) and including neutral aqueous $\mathrm{LiCl}^{0}(\mathrm{aq})$ species. Approach (2) provides a better fit of activity data in unsaturated binary solutions and accurately predicts solid solubilities up to $40 \mathrm{~mol} . \mathrm{kg}^{-1}$ and up to $523.15 \mathrm{~K}$. Therefore, this approach was used to parameterize lithium chloride mixed systems. Temperature functions for the thermodynamic solubility product (as $\log \mathrm{K}_{\text {sp }}^{0}$ ) of 5 simple lithium salts $\left(\mathrm{LiCl} .2 \mathrm{H}_{2} \mathrm{O}(\mathrm{cr})\right.$, LiCl. $\mathrm{H}_{2} \mathrm{O}(\mathrm{cr})$, LiCl (cr), LiOH. $\mathrm{H}_{2} \mathrm{O}(\mathrm{cr})$, and $\left.\mathrm{LiOH}(\mathrm{cr})\right)$ are determined. The $\log \mathrm{K}_{\mathrm{sp}}^{\mathrm{o}}$ values of 3 double lithium basic salts precipitating in the $\mathrm{LiOH}-\mathrm{LiCl}-\mathrm{H}_{2} \mathrm{O}$ system at $5_{0}^{\circ} \mathrm{C}$ (3LiOH.LiCl(cr), LiOH.LiCl(cr), and $\mathrm{LiOH.3LiCl(cr))} \mathrm{are} \mathrm{also} \mathrm{estimated} \mathrm{using} \mathrm{solubility}$ data.

KEYWORDS: Lithium, hypersaline aqueous solutions, Pitzer model, thermodynamic excess properties, solubility, mixed systems 


\section{INTRODUCTION}

The interest in lithium is increasing because of the difficulties involved in finding oil substitutes for the world's energy supply, taking into account environmental constraints. It is used, in particular, in batteries (including vehicles batteries and energy storage devices) and the demand for lithium is expected to increase greatly in the coming years (Ebensperger and others, 2005, Grosjean and others, 2012, Kushnir and Sandén, 2012). Large amounts of lithium are found in the salt flats (salars) of the Altiplanos in South America, mostly in Chile, Argentina and Bolivia (Garrett, 2004, Risacher and Fritz, 2009), in saline lakes in China (Song and Yao, 2001) and the United States, and in the Dead Sea (Warren, 2010). There may be other sources of lithium in other countries and hydrosystems, such as in some geothermal waters (Pauwels and others, 1993, 1995) and oil brines (Gruber and others, 2011). Regardless of the source and geochemical cycle of lithium, an understanding of its chemical behavior is a prerequisite for its exploration, extraction and exploitation, in particular because of the very high concentrations it can reach in aqueous solutions due to the very high solubility of the lithium salts.

Part of this understanding relies on the development of comprehensive thermodynamic models that accurately predict lithium aqueous chemistry and lithium mineral solubilities as a function of the composition of precipitates and solution concentration and at high temperature. For example, the study of lithium salt solubility diagrams is of practical importance with a view to explaining the distribution of lithium ions in natural evaporate deposits during crystallization of salts as a result of sea water evaporation and during treatment of natural deposits (Song and Yao, 2001, 2003). 
Several authors (Pitzer and Mayorga, 1973, Kim and Frederick, 1988a, Christov and others, 1994, Ojkova and others, 1998, 2000, Song and Yao, 2001, El Guendouzi and others, 2003, 2003, 2004, Nasirzadeh and others, 2005) have developed 298.15 K Pitzer equation-based models for Li interactions in binary and mixed sea-type systems. The standard temperature Pitzer models of Christov and others $(1994,2000)$ for the Li-Mg-Ca-Cl-Br- $\mathrm{H}_{2} \mathrm{O}$ system, of Song and Yao (2001) for Li chloride ternary sub-systems within the $\mathrm{Li}-\mathrm{K}-\mathrm{Mg}-\mathrm{Cl}-\mathrm{SO}_{4}-\mathrm{H}_{2} \mathrm{O}$ system, of Song and Yao (2003) for the Li-Na-K-Mg-Cl-SO $\mathrm{S}_{4}-\mathrm{H}_{2} \mathrm{O}$ system, and of Christov (1995) for Li$\mathrm{Mg}-\mathrm{Br}-\mathrm{H}_{2} \mathrm{O}$ at $343.15 \mathrm{~K}$ consider precipitation of lithium minerals. On the basis of their own high temperature osmotic coefficient data and reference activity data at lower temperature, Holmes and Mesmer (HM) developed temperature variable models for binary systems $\mathrm{LiCl}-\mathrm{H}_{2} \mathrm{O}$ (Holmes and Mesmer, 1981, 1983) and $\mathrm{LiOH}-\mathrm{H}_{2} \mathrm{O}$ (Holmes and Mesmer, 1998a). The models of $\mathrm{HM}$ are valid only up to low molality ( $\mathrm{m}_{\max }=6 \mathrm{~mol} \cdot \mathrm{kg}^{-1}$ for chloride and hydroxide systems) and therefore cannot be used for solid-liquid equilibrium calculations. With only one exception $\left(\mathrm{Li}_{2} \mathrm{SeO}_{4}-\mathrm{H}_{2} \mathrm{O}\right.$ model), all of the Pitzer models described in the literature for Li binary systems ( $\mathrm{LiCl}-\mathrm{H}_{2} \mathrm{O}, \mathrm{LiBr}-\mathrm{H}_{2} \mathrm{O}, \mathrm{LiI}-\mathrm{H}_{2} \mathrm{O}, \mathrm{LiOH}-\mathrm{H}_{2} \mathrm{O}, \mathrm{LiClO}_{4}-\mathrm{H}_{2} \mathrm{O}, \mathrm{LiNO}_{3}-\mathrm{H}_{2} \mathrm{O}, \mathrm{Li}_{2} \mathrm{SO}_{4}-\mathrm{H}_{2} \mathrm{O}$ ) have used a standard molality-based Pitzer approach for 1-1 and 1-2 types of electrolytes with three ion interaction pure electrolyte parameters $\left(\beta^{(0)}, \beta^{(1)}\right.$, and $\left.C^{\varphi}\right)$. Ojkova and others (1998) include in their model for the $\mathrm{Li}_{2} \mathrm{SeO}_{4}-\mathrm{H}_{2} \mathrm{O}$ system a fourth interaction parameter $\left(\beta^{(2)}\right)$ from basic Pitzer equations. Only two temperature variable solid-liquid equilibrium models are available in the literature for lithium chloride systems: the one from Monnin and others (2002) for the $\mathrm{LiCl}-\mathrm{H}_{2} \mathrm{O}$ system, which is based on the Pitzer equations for subzero temperatures (up to about $200 \mathrm{~K}$ ) and on the mean spherical approximation (MSA) model for temperatures up to $433 \mathrm{~K}$, and the one from Zeng and others (2007) for the $\mathrm{H}-\mathrm{Li}-\mathrm{Mg}-\mathrm{Cl}-\mathrm{H}_{2} \mathrm{O}$ system who used the BET model over the 
temperature range from 273 to $473 \mathrm{~K}$. There is no model available in the framework of the Pitzer formulation for temperatures comprised between 273.15 and $523.15 \mathrm{~K}$.

The construction of a comprehensive Pitzer model has, however, been initiated through a series of experimental measurements and parameterization of XTP- and pH-variable thermodynamic solid-liquid equilibrium models of highly soluble chloride, hydroxide, and bromide minerals precipitating within the $\mathrm{H}-\mathrm{Li}-\mathrm{Na}-\mathrm{K}-\mathrm{Mg}$-Ca-Al-Fe(II)-Fe(III)-OH-Cl-Br- $\mathrm{HSO}_{4}-\mathrm{SO}_{4}-\mathrm{H}_{2} \mathrm{O}$ system (Christov and others, 2000, Christov, 2004, 2012, Christov and Møller, 2004a, 2004b, Christov and others, 2007). The resulting consistent and extensible geochemical databases are able to describe complex systems that can be applied to natural and industrial contexts.

The objective of the present work is to continue the development of such a database, providing the Pitzer parameters that enable the accurate description of the $\mathrm{Li}-\mathrm{H}-\mathrm{Na}-\mathrm{K}-\mathrm{Cl}-\mathrm{OH}-\mathrm{H}_{2} \mathrm{O}$ system from diluted aqueous solutions up to saturation with respect to minerals, and from low (273.15 $\mathrm{K}$ ) to high temperatures (up to $523.15 \mathrm{~K}$ ).

\section{METHODOLOGY}

The specific interaction approach for describing electrolyte solutions to high concentration introduced by Pitzer $(1973,1991)$ represents a significant advance in physical chemistry that has facilitated the construction of accurate thermodynamic models (Gueddari and others, 1983, Harvie and others, 1984). It has been shown that the Pitzer approach could be expanded to accurately calculate ion activity products, and thus solubilities, in complex brines and to predict the behavior of natural fluids from subzero temperatures (Marion and others, 2003) to a very high temperature up to 573.15 K (Pabalan and Pitzer, 1987, Møller, 1988, Christov and Møller, 
2004a, 2004b, Christov and others, 2007, Møller and others, 2005, 2006, 2007, Christov, 2009, 2012).

\subsection{The Pitzer Approach}

The Pitzer specific interaction approach (Pitzer, 1973) and model equations for osmotic and activity coefficients have been discussed in detail in many publications (see references below). Depending on the chemical system or the range of salinity studied, the basic Pitzer approach has been used, modified and extended in various ways. We review here these practices in order to explain our modeling technology, which has been used to create a model for extremely high concentrated lithium chloride solutions, with a very strong association at high molality.

\subsubsection{Pitzer equations}

We give here only the equation for calculating the logarithm of the activity coefficient, $\gamma_{M}$, of a cation $M$ of charge $z_{M}$. Equation (1) refers to the basic Pitzer theory (Pitzer, 1973, Pitzer and Mayorga, 1973) and it is expressed here according to Harvie and Weare (1980). The additional terms given here with equation (1A) have been introduced later in order to take into account the

contribution of neutral species (Pitzer and Silvester, 1976, Harvie and others, 1984, Felmy and Weare, 1986).

$$
\begin{aligned}
\ln \gamma_{M}=z_{M}^{2} F+ & \sum_{a} m_{a}\left(2 B_{M a}+Z C_{M a}\right)+\sum_{c} m_{c}\left(2 \Phi_{M c}+\sum_{a} m_{a} \psi_{M c a}\right) \\
& +\sum_{a} \sum_{<a^{\prime}} m_{a} m_{a^{\prime}} \psi_{M a a^{\prime}}+\left|z_{M}\right| \sum_{c} \sum_{a} m_{c} m_{a} C_{c a} \\
& +\sum_{n} m_{n}\left(2 \lambda_{M n}\right)+\sum_{n} \sum_{a} m_{n} m_{a} \zeta_{M n a}
\end{aligned}
$$

Subscripts $c$ and $a$ refer to cations and anions and the summations are over the total number of cations or anions. The double summation index, $a<a^{\text {' }}$, denotes the sum over all distinguishable pairs of dissimilar anions. In equation (1), $B$ and $\Phi$ are measurable combinations of the second 
virial coefficients. $C$ and $\psi$ are measurable combinations of the third virial coefficients. $B$ and $C$ are parameterized from single electrolyte data, and $\Phi$ and $\psi$ are parameterized from mixed system data. $m_{i}$ is the molality of species $i(i=M, a, c, n)$.

The function $F$ is the sum of the Debye-Hückel term,

$$
F=-A^{\varphi}\left[\frac{\sqrt{I}}{(1+b \sqrt{I})}+\frac{2}{b} \ln (1+b \sqrt{I})\right]
$$

and terms with the derivatives of the second virial coefficients with respect to ionic strength (see Harvie and others, 1984). In equation (2), $b$ is a universal empirical constant assigned to be equal to 1.2. $A^{\varphi}$, the Debye-Hückel limiting law slope for osmotic coefficients, is a function of temperature, density and the dielectric constant of water (see, Møller, 1988).

For the interaction of any cation $M$ and any anion $a$, Pitzer assumes that in equation (1), $B$ has the ionic strength dependent form:

$$
\begin{aligned}
B_{M a}= & \beta_{M a}^{(0)}+\beta_{M a}^{(1)} g\left(\alpha_{1} \sqrt{I}\right) \\
& +\beta_{M a}^{(2)} g\left(\alpha_{2} \sqrt{I}\right)
\end{aligned}
$$

where $\boldsymbol{g}(\boldsymbol{x})=\mathbf{2}\left[\mathbf{1}-(\mathbf{1}+\boldsymbol{x}) \boldsymbol{e}^{-\boldsymbol{x}}\right]$, with $\mathrm{x}=\alpha_{1} \sqrt{\mathrm{I}}$ and $\alpha_{1}=2.0$

Equation (3) refers to the basic Pitzer theory, while the additional term corresponding to equation (3A) was introduced afterwards to deal with 2-2 electrolytes (Pitzer and Mayorga, 1974). Its use has been extended to other types of electrolytes as detailed below.

The $C_{M a}$ third virial coefficients (see eq 1) are assumed to be ionic strength independent. However, some terms containing $C_{M a}$ parameters have a concentration dependence given by $Z$, as: $\mathrm{Z}=\sum_{\mathrm{i}} \mathrm{m}_{\mathrm{i}}\left|\mathrm{z}_{\mathrm{i}}\right|$.

In equation 1 , the $\Phi$ terms account for interactions between two ions $i$ and $j$ of like charges. In the equation for $\Phi$, 


$$
\Phi_{i j}=\boldsymbol{\theta}_{i j}+{ }^{E} \theta_{i j}(I)
$$

$\theta_{i j}$ is the only adjustable parameter. The ${ }^{E} \theta_{i j}(I)$ term accounts for electrostatic unsymmetric mixing effects that depend only on the charges of ions $i$ and $j$ and the total ionic strength.

The $\psi_{i j k}$ parameters are used for each triple ion interaction where the ions $i, j, k$ do not all have the same sign. Their inclusion is generally important for describing solubilities in concentrated multicomponent systems.

According to the basic Pitzer equations, therefore, at constant temperature and pressure, the solution model parameters to be estimated are: 1) $\beta^{(0)}, \beta^{(1)}$, and $C^{\varphi}$ for each cation-anion pair in the pure electrolytes; 2) $\theta$ for each unlike cation-cation or anion-anion pair in electrolyte mixtures; 3) $\psi$ for each triple ion interaction where the ions do not all have the same sign in electrolyte mixtures.

During the 1970's, Pitzer and co-authors determined the ion interaction parameters for a large number of binary and ternary unsaturated solutions of electrolytes. Using the standard Pitzer approach with three $\left(\beta^{(0)}, \beta^{(1)}\right.$, and $\left.C^{\varphi}\right)$ ion-interaction binary parameters, Pitzer and Mayorga (1973) developed models for 227 pure aqueous electrolyte systems of the 1-1, 2-1, 1-2, 3-1 and 4-1 types, and Kim and Frederick (1988a) developed models for 294 binary systems of the same types plus four 1-3 electrolyte systems. These binary systems models were developed using only activity data (osmotic coefficients) in unsaturated solutions, i.e. the precipitation of solid phases was not considered. Furthermore, the parameterization of Pitzer and Mayorga (1973) (summarized also in Pitzer, 1991) focused on a good representation of activity properties (osmotic coefficients) of low to moderate molality unsaturated binary solutions alone, with a maximum molality of $6 \mathrm{~m}$ for each model. The parameterization of Kim and Frederick (1988a) extends the concentration range of application of pure electrolyte ion-interaction parameters, 
focusing on the fit of data at high molality. However, for many binary systems of the type 1-1, 21, and 3-1 the concentration extension of Kim and Frederick parameterization leads to a disagreement with the low molality osmotic coefficients data, and to much higher standard deviation values, compared to Pitzer and Mayorga (1973) parameterizations (see Christov 1994, 2004, 2005). More recent studies have also shown that, for a binary electrolytic solution containing a univalent species, either cationic or anionic, the standard Pitzer approach gives excellent model reliability from $273.15 \mathrm{~K}$ to very high temperatures (up to $573 \mathrm{~K}$ ), and from extremely low ([Al $\left.\mathrm{I}_{\text {total }}\right] \approx 10^{-7}$ mol. $\mathrm{kg}^{-1}$ in the aluminum hydroxide speciation model (Møller and others, 2006, 2007)) to very high concentrations (for example, up to $523.15 \mathrm{~K}$ and $64 \mathrm{~mol} . \mathrm{kg}^{-1}$ in the $\mathrm{NaOH}-\mathrm{H}_{2} \mathrm{O}$ system (Christov and Møller, 2004b); up to $383.15 \mathrm{~K}$ and $\approx 14.5 \mathrm{~mol} . \mathrm{kg}^{-1}$ in the $\mathrm{CaCl}_{2}-\mathrm{H}_{2} \mathrm{O}$ system (Christov and Møller, 2004a); up to $373.15 \mathrm{~K}$ and 7.64 mol.kg ${ }^{-1}$ in the $\mathrm{MgCl}_{2^{-}}$ $\mathrm{H}_{2} \mathrm{O}$ system (Christov, 2009); up to $573.15 \mathrm{~K}$ and 18 mol. $\mathrm{kg}^{-1}$ in the $\mathrm{NaBr}-\mathrm{H}_{2} \mathrm{O}$, and $\mathrm{KBr}-\mathrm{H}_{2} \mathrm{O}$ systems; and up to $523 \mathrm{~K}$ and 16.5 mol. $\mathrm{kg}^{-1}$ in the $\mathrm{CaBr}_{2}-\mathrm{H}_{2} \mathrm{O}$ system (Christov, 2012).

Using the binary system parameterization of Pitzer and Mayorga (1973), Pitzer and Kim (1974) developed models for 52 ternary mixtures of 1-1+1-1 (for example $\mathrm{HCl}-\mathrm{LiCl}-\mathrm{H}_{2} \mathrm{O}$ ), 1-1+2-1 (for example $\left.\mathrm{NaCl}-\mathrm{MgCl}_{2}-\mathrm{H}_{2} \mathrm{O}\right), 1-1+1-2,2-1+2-1$, and 2-1+2-1 brine-type electrolytes. Once again, mixed system models of Pitzer and Kim (1974) were developed using only activity data (osmotic coefficients) in unsaturated solutions, and the precipitation of solid phases was not considered. Pitzer and Kim (1974) concluded that the mixed models enabled the calculation of the activity coefficients in the ternary systems under consideration with an accuracy of 2 to $6 \%$. Kim and Frederick (1988b) performed the same work, including in their parameterization some transition metal chloride systems, for which data were available.

\subsubsection{The $\beta^{(2)}$ parameter}


Pitzer and Mayorga (1973) did not study 2-2 (for example $\mathrm{MgSO}_{4}-\mathrm{H}_{2} \mathrm{O}$ ) or higher (for example $\left.\mathrm{Al}_{2}\left(\mathrm{SO}_{4}\right)_{3}-\mathrm{H}_{2} \mathrm{O}\right)$ electrolytes. Indeed, they found that the three-parameter approach $\left(\beta^{(0)}, \beta^{(1)}\right.$, and $C^{\varphi}$, see eq 1) could not accurately fit the activity data for these types of solutions. For these electrolytes, the mean activity coefficient, $\gamma_{ \pm}$, and the osmotic coefficient, $\varphi$, drop very sharply in dilute solutions, while showing a very gradual increase, with a very broad minimum at intermediate concentrations. Pitzer and Mayorga (1974) concluded that this behavior was due to ion association reactions and that the standard approach with three estimated solution parameters cannot reproduce it. This led to a further modification of the original equations for the description of binary solutions by introducing an additional parameter, $\beta_{\mathrm{Ma}}^{(2)}$, and its associated $\alpha_{2} \sqrt{I}$ term in the $B_{M a}$ equation (see eq 3A). Pitzer and Mayorga (1974) presented these parameterizations assuming that the form of the excess functions (i.e. 3 or $4 \beta$ and $C^{\varphi}$ values, as well as the values of the $\alpha$ terms) vary with the type of electrolyte. For binary electrolyte solutions in which either the cationic or anionic species are univalent (for example $\mathrm{NaCl}$, $\mathrm{Na}_{2} \mathrm{SO}_{4}$, or $\mathrm{MgCl}_{2}$ ), the standard Pitzer approach uses 3 parameters (i.e. omits the $\beta^{(2)}$ term) and $\alpha_{1}$ equals 2.0. For the 2-2 type of electrolytes, the model includes the $\beta^{(2)}$ parameter, $\alpha_{1}$ equals 1.4 , and $\alpha_{2}$ equals 12 . This approach provides accurate models for many 2-2 electrolytes, and gives an excellent representation of activity data covering the entire concentration range from low molality up to saturation and beyond.

On the other hand, some authors found that some restrictions limit the potential of the standard Pitzer model to correctly describe activity and solubility properties in some binary electrolyte systems containing a univalent species at very high molality. One major factor determined these restrictions: type of $\varphi$ vs. $m$, or $\gamma_{ \pm}$vs. $m$ dependences at high concentration. For all of these systems, $\varphi$ vs. $m$, or $\gamma_{ \pm}$vs. $m$ curves have a broad maximum at molality approaching the molality 
of saturation (" $\mathrm{CaCl}_{2}$ type")". This "broad maximum" type of $\varphi$ vs. $m$, or $\gamma_{ \pm}$vs. $m$ dependence for highly concentrated solutions has been modeled using various extended versions of the Pitzer model, such as mole fraction models (Petrenko and Pitzer, 1997), multi-parameters models (Gruszkiewicz and Simonson, 2005), two $\mathrm{C}^{\varphi}$ extension models (Palmer and others, 2002), by inclusion of complex aqueous species (such as $\mathrm{CaCl}^{+}(\mathrm{aq})$, Sterner and others, 1998), or by accounting for temperature variations in $\alpha_{1}$ and $\alpha_{2}$ terms (Holmes and Mesmer, 1998b). In the case of the 3-2 electrolyte, $\mathrm{Al}_{2}\left(\mathrm{SO}_{4}\right)_{3}$, Reardon (1988) used the 4-parameter Pitzer approach (i.e. including $\beta^{(2)}$ ) and values of 2 and 50 for $\alpha_{1}$ and $\alpha_{2}$, respectively. To describe the high concentration solution behavior of systems showing a "smooth" maximum on $\gamma_{ \pm} v s . \mathrm{m}$ dependence, and to take strong association reactions at high molality into account, a very simple modeling technique was proposed: using the 4-parameter Pitzer approach and varying the values of $\alpha_{1}$ and $\alpha_{2}$ terms. This approach was used for various types of binary electrolyte systems at 298.15 K: 1-1 (for example, $\mathrm{HNO}_{3}-\mathrm{H}_{2} \mathrm{O}$ in Christov, 2005), 2-1 (for example, $\mathrm{CuCl}_{2}-\mathrm{H}_{2} \mathrm{O}$ in Christov, 1994), 1-2 (for example, $\mathrm{Na}_{2} \mathrm{Cr}_{2} \mathrm{O}_{7}-\mathrm{H}_{2} \mathrm{O}$ in Christov and others, 1999), 3-1 (for example, $\mathrm{FeCl}_{3}-\mathrm{H}_{2} \mathrm{O}$ in Christov, 2004), and 3-2 types (for example, $\mathrm{Al}_{2}\left(\mathrm{SO}_{4}\right)_{3}(\mathrm{aq})-\mathrm{H}_{2} \mathrm{O}$ in Christov, 2001a). The resulting models reduce the standard deviation $(\sigma)$ values of experimental activity data fitting and extend the application range of the binary system models to the highest molality, close or equal to the molality of saturation, m(sat). It was found that by varying the values of $\alpha_{1}$ and $\alpha_{2}$ terms, it was possible to vary the concentration range of binary solutions at which association reactions became more important, and this should be taken into account when introducing the $\beta^{(2)}$ parameter. According to Christov (2005), a model that uses $\alpha_{1}=1.4$ and $\alpha_{2}=$ 12 takes association reactions into account only for low molality solutions, while combinations of $\alpha_{1}=2$ and $\alpha_{2}=(1$ or -1$)$ can be used if ion association occurs at higher molality. All these 
approaches for binary systems were successfully used to develop models of multicomponent systems such as Na-K-Cl-SO ${ }_{4}-\mathrm{Cr}_{2} \mathrm{O}_{7}-\mathrm{H}_{2} \mathrm{O}$ (Christov, 1998, 2001b), or K-Mg-Al-Cl-SO ${ }_{4}-\mathrm{H}_{2} \mathrm{O}$ (Christov, 2001a). On the other hand, to correctly describe the very low solubility of portlandite $\left(\mathrm{Ca}(\mathrm{OH})_{2}(\mathrm{cr})\right)$ in pure water, a case of 2-1 electrolyte: $\mathrm{Ca}(\mathrm{OH})_{2}-\mathrm{H}_{2} \mathrm{O}$, Christov and Møller (2004a) also used the $\beta^{(2)} 4$-parameter approach (with $\alpha_{1}=1.4$ and $\alpha_{2}=12$ ) in their 273.15 $573.15 \mathrm{~K}$ model instead of introducing the well-defined $\mathrm{Ca}(\mathrm{OH})^{+}(\mathrm{aq})$ species.

For many of the binary solutions considered above, there is, however, experimental evidence of the formation of aqueous complexes (for example $\mathrm{CuCl}^{+}(\mathrm{aq}), \mathrm{AlSO}_{4}{ }^{+}(\mathrm{aq})$, or $\mathrm{FeCl}^{2+}(\mathrm{aq})$ ) that are taken into account in other approaches of aqueous solution chemistry. Although the solution model developed with the 4-parameter Pitzer approach with no aqueous complexes differs from others that take into account aqueous complexes for the same solutions, it is simple and provides an accurate description of the thermodynamic properties, including solubilities.

\subsubsection{Ion association}

In some instances, there are much stronger bonds formed between some ionic species than can be modeled with Pitzer type equations, and it is necessary to consider the formation of particular aqueous species (Harvie and others, 1984, Felmy and Weare, 1986, Møller, 1988; Greenberg and Møller, 1989, Christov and Møller, 2004b, Møller and others, 2005, 2006, 2007, Sterner and others, 1998; Rard and Clegg, 1997; Pitzer and others, 1999). Harvie and others (1984) discussed on the correlation between the ion pairing and the $\beta^{(2)}$ parameter for rather low molality. They

provided a key for selecting one option instead of another: for strong ion associations, $\beta^{(2)}$ takes strong negative values indicating that using an ion association approach, with an association constant, is more efficient and should be preferred. The adding of a charged contact ion pair to the solution model requires the determination of not only a stability constant to describe the ion pair, but also 
ion interaction parameters between the ion pair and each of the other species in the solution. For example the $273.15 \mathrm{~K}-523.15 \mathrm{~K}$ model of Christov and Møller (2004b) for the binary system $\mathrm{H}_{2} \mathrm{SO}_{4}-\mathrm{H}_{2} \mathrm{O}$ was developed by including the contact ion pair $\mathrm{HSO}_{4}{ }^{-}(\mathrm{aq})$ and therefore the system is considered to be a mixed system $\mathrm{H}-\mathrm{HSO}_{4}-\mathrm{SO}_{4}-\mathrm{H}_{2} \mathrm{O}$. As a result, the model development required the determination of the chemical potential of the bisulfate ion $\left(\mu\left(\mathrm{HSO}_{4}{ }^{-}(\mathrm{aq})\right)\right.$ and the consideration of many potential interactions: $\mathrm{H}-\mathrm{HSO}_{4}, \mathrm{H}-\mathrm{SO}_{4}, \mathrm{SO}_{4}-\mathrm{HSO}_{4}, \mathrm{H}-\mathrm{SO}_{4}-\mathrm{HSO}_{4}$. The complications associated with adding the $\mathrm{HSO}_{4}{ }^{-}(\mathrm{aq})$ ion pair increase in the case of mixed sulfuric acid systems. For example, in order to develop an accurate model for $\mathrm{H}_{2} \mathrm{SO}_{4}-\mathrm{K}_{2} \mathrm{SO}_{4}$ $\mathrm{H}_{2} \mathrm{O}$, it was necessary to estimate, in addition to all of the sulfate parameters, T-variation bisulfate parameters of $\mathrm{K}-\mathrm{HSO}_{4}, \mathrm{~K}-\mathrm{H}-\mathrm{HSO}_{4}$, and $\mathrm{K}-\mathrm{SO}_{4}-\mathrm{HSO}_{4}$ interactions, and to determine the chemical potential of bisulfate solids, using only the available solubility data. However, in most cases, the very limited experimental database that does exist does not make it possible to determine the pure electrolyte parameters for these ion pairs (for example parameters for $\mathrm{FeCl}^{2+}-$ $\mathrm{Cl}^{-}$interactions). The inclusion of an ion association reaction in a Pitzer-based model without appropriate ion interaction binary and mixing parameters determined from an extensive and parameters-sensitive experimental database can lead to inappropriate and even completely wrong activity and solubility model predictions.

In spite of spectroscopic or other experimental indications that a particular complex exists in a solution, it might be possible to develop a sufficiently accurate solution model to describe the excess properties without including explicitly these complexes. Indeed, in light of the above considerations, simple evidence of ion-association in concentrated solutions is not a sufficient reason for incorporating ion pairs in a Pitzer-based activity model. Reasons for introducing a contact ion pair in the Pitzer based activity model would include 1) a failure to accurately predict 
observed thermodynamic properties such as osmotic/activity coefficients and solubilities in binary and complex systems, 2) a pH-dependent behavior of binary systems, and 3) experimental evidence of the abundance of the contact ion pair compared to the dissociated aqueous species, which evidences the strength of the ion association.

\section{Binary and Mixed Systems Including Neutral Species (see equation (1A))}

Fluids commonly encountered in natural systems include dissolved neutral species such as carbon dioxide $\left(\mathrm{CO}_{2 \text { (aq) }}\right)$ and $\mathrm{SiO}_{2 \text { (aq) }}$. Further development of Harvie and Weare's (1980) model to include carbon dioxide and its hydrolysis products (Harvie and others, 1984) required an additional modification of fundamental Pitzer equations. This modification included terms, $\lambda_{n c}$ or $\lambda_{n a}$, to account for interactions between neutral solutes, $n$, and dissolved cations, $c$, and anions, $a$. The behavior of $\mathrm{CO}_{2(\mathrm{aq})}$ in $\mathrm{NaCl}-\mathrm{H}_{2} \mathrm{O}$ solutions could then be described by the following neutral species-ion interaction parameters: $\lambda_{\mathrm{CO}_{2}, \mathrm{Na}}, \lambda_{\mathrm{CO}_{2}, \mathrm{Cl}}$. Analyses of interactions in more complex natural waters demonstrated the need to add an additional interaction parameter, $\zeta_{\text {nca }}$, to account for ternary interactions between an anion, a cation and a neutral solute (such as $\zeta_{\mathrm{SiO}, \mathrm{Na}, \mathrm{Cl}}$ : Felmy and Weare, 1986). Using spectroscopic measurements, Felmy and others (2001) further developed their model by introducing polymerized silica species in order to describe the behavior of silica at high $\mathrm{pH}$. To describe the extremely low solubility of calcium sulfate solids in pure water and in the mixed Na-K-Ca-Cl-SO $\mathrm{SO}_{4}-\mathrm{H}_{2} \mathrm{O}$ system, Møller (1988) and Greenberg and Møller (1989) also included the neutral $\mathrm{CaSO}_{4}{ }^{0}(\mathrm{aq})$ species without evaluating $\mathrm{CaSO}_{4}{ }^{0}$ (aq)-ion interaction parameters. The neutral $\mathrm{Al}(\mathrm{OH})_{3}{ }^{0}(\mathrm{aq})$ species is also included in the aluminum hydroxide speciation 273.15-563.15 K model described in (Møller and others, 2006, 2007). The inclusion of this aqueous complex together with estimated $\mathrm{Al}(\mathrm{OH})_{3}{ }^{0}(\mathrm{aq})$-ion interaction 
parameters into a model gives an excellent fit of experimental gibbsite $\mathrm{Al}(\mathrm{OH})_{3}(\mathrm{cr})$ and boehmite $\mathrm{AlOOH}(\mathrm{cr})$ solubility data in the intermediate $\mathrm{pH}$ range.

\subsection{Parameterization}

We therefore propose the following parameterization procedure for models based on Pitzer formalism for binary electrolyte systems with at least one univalent ion, or of 3-2 type:

(i) Parameterize a standard Pitzer equation model using three single electrolyte interaction parameters $\left(\beta^{(0)}, \beta^{(1)}\right.$, and $\left.C^{\varphi}\right)$.

(ii) If model predictions are not in agreement with raw experimental activity and solubility data, develop a new model using four interaction parameters from basic Pitzer equations $\left(\beta^{(0)}, \beta^{(1)}, \beta^{(2)}\right.$ and $\left.C^{\varphi}\right)$. Vary the values of $\alpha_{1}$ and $\alpha_{2}$ terms to achieve the best fit of data for the entire concentration and temperature range.

(iii) If neither (i) nor (ii) provides an acceptable fit, include in the model one or more ion pairs with their stability constant and binary and mixing ion interaction or neutral species-ion interaction parameters for all aqueous species. To avoid the redundancy of having both the $\beta^{(2)}$ parameter and the contact ion pair to account for the ionic association in solutions it is preferable to develop a three parameter model $\left(\beta^{(0)}, \beta^{(1)}\right.$, and $\mathrm{C}^{\varphi}$ ) adapted to complex-free solutions.

(iv) Confirm the suitability of the accepted models for binary systems by developing accurate models for higher-order mixed systems, where aqueous solutions can be more concentrated than in the binary systems. 
According to Pitzer's theory, the $\beta^{(2)}$ parameter fully accounts for association reactions at low molality for 2-2 electrolyte systems. Therefore, including a contact ion pair in a model for this type of system is inappropriate and can lead to erroneous model calculations of the solubility product of precipitating solids (Christov, 2012).

The temperature-variation model for lithium binary and mixed system solubility is developed using the following classical approach. Activity data for unsaturated solutions are used to estimate interaction parameters for low and moderate electrolyte concentrations. Solubility data in binary and mixed solutions are also used to broaden the temperature and concentration ranges of parameterization. Using the same approach as in previous studies, in order to avoid the overlapping of pure electrolyte and mixed solution parameters, we developed the models for $\mathrm{Li}$ binary systems using only the data for these binary systems, and mixed solution models were parameterized using only data for a mixed system. In our binary and mixed model parameterization we used only raw experimental thermodynamic values (osmotic coefficients, water activity, and minerals solubility) derived directly from experimental measurements (isopiestic and vapor pressure studies, and solubility experiments). Results of the parameterization are expressed in terms of standard deviation $(\sigma)$, as defined in Christov and Møller (2004a). Note that the mean activity coefficients recommended in the literature are model-dependent and are therefore not used in the parameterization process. However, some of these data are compared to our results to evaluate the solution models for Li binary systems.

The new Li models are parameterized using PEST (Doherty, 2004), a software for modelindependent parameter estimation and uncertainty analysis, in combination with PhreeqC v2.15 (Parkhurst and Appelo, 1999), used for the calculation of the excess properties of aqueous solutions. PhreeqC includes the Phrqpitz modules (Plummer and others, 1988), which are based 
on the Pitzer formalism. We modified the PhreeqC code in order to be consistent with the temperature function used by Christov and Møller (2004b) for the solution parameters. The Debye-Hückel parameter $\mathrm{A}^{\varphi}$ is adapted in PhreeqC using the equations of Bradley and Pitzer (1979) and of Pitzer and others (1984). Møller (1988) used the same $\mathrm{A}^{\varphi}$ data (from Pitzer and others, 1984) to develop her T-function. Therefore, both temperature functions give almost the same $\mathrm{A}^{\varphi}$ values (with less than $0.066 \%$ difference) at every temperature between 273.15 and $523.15 \mathrm{~K}$.

We used two different equations to describe the temperature dependence of model parameters. Temperature dependence for the thermodynamic solubility product (as $\log \mathrm{K}_{\mathrm{sp}}^{\mathrm{o}}$ ) and the equilibrium dissociation constants of ion pairs (as Log $\mathrm{K}$ ) is built into the model by adjusting selected constants in the following equation:

$$
\log K=A_{1}+A_{2} T+A_{3} / T+A_{4} \log (T)+A_{5} / T^{2}
$$

For Pitzer ion-ion and neutral species-ion binary and ternary interaction parameters $(\mathrm{P})$, the temperature function is the same as in (Christov and Møller, 2004a,b):

$$
P(T)=a_{1}+a_{2} T+a_{3} T^{2}+a_{4} T^{3}+a_{5} / T+a_{6} \ln (T)+a_{7} /(T-263)+a_{8} /(680-T)
$$

In equations (6) and (7), temperature is in Kelvin, and $\mathrm{A}_{i}(i=1$ to 5$)$ and $\mathrm{a}_{j}(j=1$ to 8$)$ are the parameters to be adjusted. In some cases, parameters $\mathrm{A}_{i}$ can be directly derived from sets of standard thermodynamic properties including Gibbs free energy, enthalpy, entropy and calorific capacity (see for instance Blanc and others, 2012). We determined Log $\mathrm{K}_{\text {sp }}^{\mathrm{o}}$ values for $\mathrm{Li}$ minerals using the estimated model solution parameters and experimental equilibrium solubility data in binary and mixed Li systems. 


\section{MODEL PARAMETERIZATION AND RESULTS}

Christov and Møller (2004b) described the temperature (from 273.15 K to $523.15 \mathrm{~K}$ ) dependent high quality models of solution behavior and (solid-liquid) equilibrium for all binary and mixed sub-systems in the quinary $\mathrm{H}-\mathrm{Na}-\mathrm{K}-\mathrm{Cl}-\mathrm{OH}-\mathrm{H}_{2} \mathrm{O}$ system. These models are in excellent agreement with data for low molality activity, E.M.F, and $K_{w} / Q_{w}$ for unsaturated solutions, and with data for high-concentration acid-base mineral solubility data. We have developed a model for lithium mixed systems ( $\left.\mathrm{Li}-\mathrm{H}-\mathrm{Na}-\mathrm{K}-\mathrm{Cl}-\mathrm{OH}-\mathrm{H}_{2} \mathrm{O}\right)$ using the parameterization from Christov and Møller (2004b) without any additional adjustments of the values for the binary and mixed ion-interaction parameters and the chemical potential of sodium and potassium chloride and hydroxide minerals. The remaining models to be considered to complete the Li brine system series are those for binary $\left(\mathrm{LiCl}-\mathrm{H}_{2} \mathrm{O}\right.$ and $\left.\mathrm{LiOH}-\mathrm{H}_{2} \mathrm{O}\right)$ and ternary $\left(\mathrm{LiCl}-\mathrm{HCl}-\mathrm{H}_{2} \mathrm{O}\right.$, LiCl-NaCl$\mathrm{H}_{2} \mathrm{O}$, LiCl-KCl- $\mathrm{H}_{2} \mathrm{O}$, LiOH-NaOH-H ${ }_{2} \mathrm{O}, \mathrm{LiOH}-\mathrm{KOH}-\mathrm{H}_{2} \mathrm{O}$, and $\mathrm{LiOH}-\mathrm{LiCl}-\mathrm{H}_{2} \mathrm{O}$ ) systems. All of these lithium subsystems are included in the model parameterization presented here.

For parameterizing equilibrium models that can predict aqueous solution behavior and solidliquid equilibria in binary and complex systems, the most reliable and complementary experimental data are low- and high-molality osmotic coefficient and/or water activity data and solid solubility data (Christov, 2005, 2012). This type of data is therefore used throughout our study.

\subsection{Binary $\mathrm{LiCl}-\mathrm{H}_{2} \mathrm{O}$ System}

\subsubsection{Selection of experimental data}

Numerous experimental data, both for solution properties and solid solubility, are available for the simple binary $\mathrm{LiCl}-\mathrm{H}_{2} \mathrm{O}$ system at various temperatures and molality (table 1). Aqueous solution properties are mostly restricted to moderate salinities and seldom reach or approach the 
solubility of solid phases for the $\mathrm{LiCl}-\mathrm{H}_{2} \mathrm{O}$ system (fig. 1). Osmotic data are available for $\mathrm{LiCl}$ molalities ranging from 0.001 to $20.95 \mathrm{~mol} / \mathrm{kg}$ at $298.15 \mathrm{~K}$ (Robinson and Stokes, 1949, Hamer and $\mathrm{Wu}, 1972$ ), from 0.1 to $18.6 \mathrm{~mol} / \mathrm{kg}$ between 273.15 and $373.15 \mathrm{~K}$ (Gibbard and Scatchard, 1973, Patil and others, 1990), from 7.42 to 20.95 at $428.15 \mathrm{~K}$ (Brendler and Voigt, 1994), from 0.68 to 6.30 between 498.15 and $523.15 \mathrm{~K}$ (Holmes and Mesmer, 1983). Additional osmotic data are provided at 318.15 and $353.15 \mathrm{~K}$, but only for $\mathrm{LiCl}$ molalities up to $4.8 \mathrm{~mol} / \mathrm{kg}$ (Hellams and others, 1965, Moore and others, 1972) and between 383.15 and $473.15 \mathrm{~K}$ for molalities up to 6 $\mathrm{mol} / \mathrm{kg}$ (Holmes and Mesmer, 1981). Vapor pressure measurements above $\mathrm{LiCl}$ aqueous solutions have been done by Kangro and Groeneveld (1962) up to $20 \mathrm{~mol} / \mathrm{kg}$, at 293.15 and 298.15 K. These data are not used in the parameterization. However, we used these high molality data to validate the model with an independent check, after conversion of vapor pressure into osmotic coefficient.

Data from Brendler and Voigt (1994) at $428.15 \mathrm{~K}$ have been excluded from parameterization. The main reason for exclusion of these data is their inconsistency with data from others at other temperatures, and with predictions of our final $\mathrm{LiCl}$ model. According to our test, this inconsistency is mainly due to an inappropriate solution model for the reference solutions used in Brendler and Voigt (1994) experiments. They used $\mathrm{MgCl}_{2}$ as the reference electrolyte. According to the authors, the reported osmotic coefficient data for $\mathrm{MgCl}_{2}$ do not permit development of accurate model for aqueous $\mathrm{MgCl}_{2}-\mathrm{H}_{2} \mathrm{O}$ solutions. Therefore, in their calculations of the osmotic coefficient of $\mathrm{LiCl}$, Brendler and Voigt (1994) used the data for reference standard from Valyashko and others (1988), and not a prediction of the $\mathrm{MgCl}_{2}-\mathrm{H}_{2} \mathrm{O}$ model of Pabalan and Pitzer (1987). This may in turn lead to questionable calculated values of the osmotic coefficient of $\mathrm{LiCl}$ aqueous solutions. The model for $\mathrm{MgCl}_{2}$ implemented in our 
database is from Christov (2009), which gives osmotic coefficients predictions much closer to the Pabalan and Pitzer (1987) model, than to the data from Valyashko and others (1988), at least up to $100^{\circ} \mathrm{C}$. Using Christov (2009) model for interpreting isopiestic measurements of Brendler and Voigt (1994) leads to values of osmotic coefficients for $\mathrm{LiCl}$ aqueous solutions lower than recommended by these authors. All osmotic coefficients data available in literature for $\mathrm{LiCl}-\mathrm{H}_{2} \mathrm{O}$ systems are shown on Fig. 1.

According to the experimental solubility data there are three solid phases, which precipitated from saturated binary $\mathrm{LiCl}-\mathrm{H}_{2} \mathrm{O}$ solutions from $273.15 \mathrm{~K}$ to $523.15 \mathrm{~K}$ : $\mathrm{LiCl} .2 \mathrm{H}_{2} \mathrm{O}$ (cr) (from $273.15 \mathrm{~K}$ to $\approx 293.15 \mathrm{~K}), \mathrm{LiCl} . \mathrm{H}_{2} \mathrm{O}(\mathrm{cr})($ from $\approx 293.15 \mathrm{~K}$ to $\approx 367.15 \mathrm{~K})$, and $\mathrm{LiCl}(\mathrm{cr})($ from $\approx$ $367.15 \mathrm{~K}$ to $\approx 523.15 \mathrm{~K}$ ). According to Kirgintsev and others (1972), $\mathrm{LiCl}_{2} 2 \mathrm{H}_{2} \mathrm{O}$ (cr) to LiCl. $\mathrm{H}_{2} \mathrm{O}(\mathrm{cr})$ and $\mathrm{LiCl} . \mathrm{H}_{2} \mathrm{O}(\mathrm{cr})$ to $\mathrm{LiCl}(\mathrm{cr})$ phase transitions in contact with the aqueous solution occur at 292.55 and $19.45 \mathrm{~mol} / \mathrm{kg}$, and $369.15 \mathrm{~K}$ and $30.27 \mathrm{~mol} / \mathrm{kg}$, respectively. According to solubility data, as well as to the solubility-temperature relationship given by Monnin and others (2002) (see their table 1), which is based on the compilation of Cohen-Adad (1991), the solubility of lithium chloride solids sharply increases with temperature: from $\approx 20 \mathrm{~mol} / \mathrm{kg}$ at a temperature of 293.15 to $41 \mathrm{~mol} / \mathrm{kg}$ at $523.15 \mathrm{~K}$. The $\mathrm{LiCl} .2 \mathrm{H}_{2} \mathrm{O}(\mathrm{cr}), \mathrm{LiCl} \cdot \mathrm{H}_{2} \mathrm{O}(\mathrm{cr})$, and $\mathrm{LiCl}(\mathrm{cr})$ solubility data used in parameterization for temperatures between 273.15 and $433.15 \mathrm{~K}$ are from Farelo and others (2005) and from compilations of Linke (1965), Zdanovskii and others (1973) and Garrett (2004). At higher temperature (473.15 and 523.15 K) the smoothed data of Monnin and others (2002) are used. With only two exception sets $\left(\mathrm{LiCl} .2 \mathrm{H}_{2} \mathrm{O}(\mathrm{cr})\right.$ solubility at $273.15 \mathrm{~K}$ (Garrett, 2004) and at $283.15 \mathrm{~K}$ (Zdanovskii and others, 1973) the data are in a very good agreement. Therefore, only this two inconsistent data points were excluded from parameterization. All available solubility data are also given on Fig. 1. As can be seen, there is a 
lack of activity data for high concentrated unsaturated $\mathrm{LiCl}-\mathrm{H}_{2} \mathrm{O}$ solutions at high temperatures above $373.15 \mathrm{~K}$. Therefore, it was a big challenge to evaluate pure electrolyte parameters describing accurately the solution behavior for the whole molality range up to saturation, especially at high temperature.

\subsubsection{Model parameterization}

The parameterization procedure involves two different steps for each system under consideration: first binaries, then ternary sub-systems. For a monovalent electrolyte like $\mathrm{LiCl}$, a simple fully dissociated representation of the system should allow the description of its behavior as a function of salinity and temperature, the associated $\mathrm{Li}^{+}-\mathrm{Cl}^{-}$temperature-dependent specific interaction parameters being $\beta^{(0)}, \beta^{(1)}$, and $C^{\varphi}$. However, as pointed out by Monnin and others (2002) and discussed below, due to the very high solubility of lithium chloride, this simple chemical representation does not describe the experimental data accurately enough. For systems that can be very highly concentrated or show a strong curvature of the osmotic coefficient at high salinities, some authors add the $\beta^{(2)}$ interaction parameter in their fitting procedure (Zhou and others, 2003, Christov, 2005), with a value of \pm 1 for the related $\alpha_{2}$ parameter. In some cases, $\alpha_{2}$ is also adjusted (Rumyantsev and others, 2004, Zhang and others, 2005). The $\beta^{(2)}$ parameter was originally introduced by Pitzer (see $\S 2.1 .2$ ) to deal with symmetrical 2:2 electrolytes. We tested this option and call it "model 1" below.

This work aimed to produce interaction parameters that are compatible with an extensive existing database. Instead of the $\beta^{(2)}$ interaction parameter, we included the $\mathrm{LiCl}^{0}(\mathrm{aq})$ neutral aqueous species in the chemical description of the system, in addition to the $\mathrm{Li}^{+}$and $\mathrm{Cl}^{-}$ions, in order to improve model performance. As a consequence, the specific interaction parameters, $\lambda_{\mathrm{Li}-}$ 
$\mathrm{LiCl}, \lambda_{\mathrm{Cl}-\mathrm{LiCl}}$, and $\zeta_{\mathrm{Li}-\mathrm{Cl}-\mathrm{LiCl}}$, and the equilibrium constant for the $\mathrm{Li}^{+}+\mathrm{Cl}^{-}=\mathrm{LiCl}^{0}(\mathrm{aq})$ reaction had to be included in what we call "model 2 " below. However, in order to reduce the number of parameters to be fitted, we set these neutral species-ions interaction parameters to 0 in a first approximation. This enabled us to describe with a high level of confidence the whole set of experimental data for both osmotic coefficient and minerals solubility (see below).

There is few available data on aqueous properties up to saturation with respect to mineral phases at high temperatures (> 373.15 K). Depending on the model ( 1 or 2$)$, we were able to fill this gap using aqueous and solubility data simultaneously in the fitting procedure.

For both models, parameters were fitted with the numerous experimental data that cover a wide range of temperatures (from 273.15 to $523.15 \mathrm{~K}$ ) and salinities (from 0 to $20 \mathrm{~mol} / \mathrm{kg}$ for osmotic coefficients (fig. 2) and up to $41 \mathrm{~mol} / \mathrm{kg}$ for mineral solubility data (fig. 3). On the whole, model 2 describes experimental data better than model 1 . The standard deviation, $\sigma$, for the entire set of osmotic coefficient data (349 points) is 0.0534 for model 1 and 0.0221 for model 2 . The 16 experimental osmotic coefficients from Brendler and Voigt (1994) and the 36 data points (calculated from vapor pressure measurements) from Kangro and Groeneveld (1962) were included in the calculation of the deviation. They are only used here to check the quality of parameterization and point out discrepancies. The standard deviation, $\sigma$, for the whole set of solubility data (43 points), is 0.2922 for model 1 and 0.1380 for model 2 . Model 2 reproduces experimental solubility data up to $523.15 \mathrm{~K}$ and $41 \mathrm{M}$ of $\mathrm{LiCl}$, whereas model 1 fails at temperatures above $490 \mathrm{~K}$ and molalities above $37 \mathrm{M}$.

More detailed information on standard deviations for the two experimental datasets (osmotic coefficient and mineral solubility) is given in table 1. 
Specific interaction parameters were plotted as a function of temperature (fig. 4). For model 2, all parameters vary smoothly with temperature, and $\beta^{(0)}$ and $\beta^{(1)}$ even have an almost linear temperature dependence. These are good model stability criteria. The parameters of the temperature functions consistent with equation (2) are given in table 2 .

The adjustment procedure also provides temperature functions for equilibrium constants for the dissolution reaction of $\mathrm{LiCl} . n \mathrm{H}_{2} \mathrm{O}(\mathrm{cr})$ salts $\left(n=0,1\right.$ or 2): $\mathrm{LiCl} . n \mathrm{H}_{2} \mathrm{O}(\mathrm{cr})=\mathrm{Li}^{+}+\mathrm{Cl}^{-}+n \mathrm{H}_{2} \mathrm{O}$, and for the formation of the contact ion pair $\mathrm{LiCl}^{0}$ in model 2. The relevant parameters are given in table 3 and equilibrium constants have been plotted, alongside literature values for comparison, as a function of temperature (fig. 5). Equilibrium constants for $\mathrm{LiCl}_{1} \mathrm{H}_{2} \mathrm{O}$ (cr) and $\mathrm{LiCl} .2 \mathrm{H}_{2} \mathrm{O}(\mathrm{cr})$ come from Monnin and others (2002). The value at $298.15 \mathrm{~K}$ for $\mathrm{LiCl} . \mathrm{H}_{2} \mathrm{O}(\mathrm{cr})$ is from Christov (2005). The functions determined by us are in rather good agreement with these data. Values for $\mathrm{LiCl}(\mathrm{cr})$ come either from Monnin and others (2002) or were calculated using the standard thermodynamic properties of $\mathrm{LiCl}(\mathrm{cr})$ formation $\left(\Delta H_{f}^{\circ}, S^{\circ}\right.$ and $\left.C_{p}\right)$ determined by Chase (1998) from calorimetric measurements, and of $\mathrm{Li}^{+}$and $\mathrm{Cl}^{-}$ions determined by Shock and Helgeson (1988) using the CODATA (1978) recommended values for the elements and aqueous species. Our results are much more consistent with the calorimetric data of Chase (1998) than with those of Monnin and co-workers. We also checked our models by comparing the invariant points in the $\mathrm{LiCl}-\mathrm{H}_{2} \mathrm{O}$ system calculated using models 1 and 2 to experimental data (table 4). The match is satisfactory - the slight discrepancy being due to the smoothing of the temperature function of the salt crystal solubility products.

\section{Activity coefficients, activity of water and relative humidity}

As a result of the fitting procedure, individual activity coefficients for $\mathrm{Li}^{+}$and $\mathrm{Cl}^{-}$can be calculated as a function of total molality of dissolved $\mathrm{LiCl}$ at various temperatures. As indicated 
by Plummer and others (1988), individual-ion activities and activity coefficients (equation 1) cannot be measured independently: Only are valid combinations of individual activity coefficients to define mean activity coefficients of neutral combinations of ions. If the dissolved electrolyte is fully dissociated, the mean activity coefficient $\left(\gamma_{ \pm}\right)$is calculated after the individual activity coefficients according to: $\gamma_{ \pm}=\left(\gamma_{\mathrm{Li}+} \gamma_{\mathrm{Cl}-}\right)^{1 / 2}$. If dissociation is not complete, the degree of dissociation $(\delta)$ must be taken into account (Zhang and others, 2011). The mean activity coefficient is then rewritten as: $\gamma_{ \pm}=\delta \times\left(\gamma_{\mathrm{Li}+} \gamma_{\mathrm{Cl}}\right)^{1 / 2}$, where $\delta=\mathrm{m}\left(\mathrm{Li}^{+}\right) /\left[\mathrm{m}\left(\mathrm{Li}^{+}\right)+\mathrm{m}\left(\mathrm{LiCl}^{0}\right)\right]$.

Mean activity coefficients calculated in this manner were plotted (fig. 6 ) and given in table 5 for comparison with recommended values from the literature. $\mathrm{LiCl}$ mean activity coefficients are extremely variable (between $<1$ at low salinities and/or at high temperatures and $>60$ close to mineral saturation at low temperatures). Mean activity coefficients calculated with model 2 are generally closer to the values recommended in the literature than results of model 1 (table 5). None of the models available in the literature provide mean activity coefficients over the entire range of temperatures and concentrations covered in table 5. This illustrates the complexity of the system and the good performance of the models described here.

As an ultimate test of our models, calculated values for deliquescence relative humidity (DRH), the osmotic coefficient and the mean activity coefficient of $\mathrm{LiCl}$ at saturated lithium binary solution at $298.15 \mathrm{~K}$ are compared to recommended experimental values and the results of reference models (table 7). A good agreement is obtained with recommended experimental data, in particular for model 2 which provides better results than the reference models listed in the table.

All performed tests and calculations show that predictions of model 2, which uses the neutral ion pair $\operatorname{LiCl}^{0}(\mathrm{aq})$ are more consistent with experimental data, than the predictions of more widely 
used model 1. It can be suggested that total dissociation of dissolved species in the extremely high salinity $\mathrm{LiCl}-\mathrm{H}_{2} \mathrm{O}$ solutions is not complete, and to account strong association at high molality it is necessary to introduce into a model the ion pair $\operatorname{LiCl}^{0}(\mathrm{aq})$.

\section{Aqueous speciation}

Since dissolved $\mathrm{LiCl}$ is not fully dissociated, $\mathrm{Li}$ and $\mathrm{Cl}$ speciation in the aqueous solution was calculated. The $\operatorname{LiCl}^{0}(\mathrm{aq}) \mathrm{mol} \%$, equal to $\left.100 \mathrm{~m}\left(\mathrm{LiCl}^{0}(\mathrm{aq})\right) /\left[\mathrm{m}_{\left(\mathrm{Li}^{+}\right.}\right)+\mathrm{m}\left(\mathrm{LiCl}^{0}(\mathrm{aq})\right)\right]$, is plotted in figure 7 as a function of total $\mathrm{LiCl}$ molality at various temperatures. At low temperatures, from low concentrations up to about a molality of $10 \mathrm{~mol} / \mathrm{kg}$, the dissolved $\mathrm{LiCl}$ is almost fully dissociated. This is consistent with the classic use of the Pitzer approach. At higher molalities, the neutral $\operatorname{LiCl}^{0}(\mathrm{aq})$ contact ion pair is increasingly abundant, which is in agreement with the experimental observation of a contact ion pair made by Rudolph and others (1995), using Raman spectroscopy, in $\mathrm{LiCl}$ aqueous solutions at $295 \mathrm{~K}$. These authors observed this neutral species for salt/water molar ratios of less than 1:4, which corresponds to a molality of about $14 \mathrm{M}$ and is consistent with the results of model 2. Moreover, as the temperature increases, the fractions of the $\mathrm{LiCl}^{0}$ (aq) species increase, indicating a stabilization of this species with temperature. This is in agreement with the evolution of the dissociation constant with temperature (above $673.15 \mathrm{~K}$ ) as reported by Sverjensky and others (1997). As an illustration of this, we have plotted $\mathrm{LiCl}$ speciation along the solution-mineral equilibrium line (fig. 8). Up to $523.15 \mathrm{~K}$, the total number of aqueous ions $\left(\mathrm{m}_{\mathrm{Li}+}+\mathrm{m}_{\mathrm{Cl}}\right)$ never exceeds the number of water molecules $(55.508 \mathrm{~mol} / \mathrm{kg})$. This is qualitatively consistent with studies that report that at high concentrations - up to at least $18.5 \mathrm{~m}$ - a hydration shell is preserved around $\mathrm{Li}^{+}$ions (Tanaka and others, 1987, Egorov and others, 2003, Petit and others, 2008), and even the water content of this hydration shell can drop to two water molecules (Harsányi and others, 2011). However, for such high salinities, the 
system can hardly be considered to be an aqueous solution. This means that, using the specific interaction parameters, the Pitzer formalism can describe, in the same way, different chemical processes.

Conversely, with a fully dissociated description of the dissolved $\mathrm{LiCl}$, the relative quantities of water molecules and ionic species would be conducive to the formation of a majority of contact ion pairs, but without any possibility of creating covalent bonds. The creation of covalent bonds would lead to the formation of neutral complexes, which is impossible due to the initial hypothesis of fully dissociated $\mathrm{LiCl}$. These contradictory arguments support the second model proposed here, which is used hereafter for dealing with ternary systems.

\subsection{Binary $\mathrm{LiOH}-\mathrm{H}_{2} \mathrm{O}$ System}

The recent parameters provided by Monnin and Dubois (2005) allow describing the osmotic coefficients of $\mathrm{LiOH}$ aqueous solutions as a function of temperature up to the solubility of $\mathrm{LiOH}$ solid salts. However, new experimental measurements of osmotic coefficient were published in the same time by Nasirzadeh et al. (2005) which could not be used by Monnin and Dubois (2005). Furthermore, the behavior of osmotic coefficients calculated with Monnin and Dubois' parameters beyond the solubility limit of $\mathrm{LiOH}$ salts become instable, and the possibility to extend the use of this set of parameters to ternary systems involving highly soluble salts, like $\mathrm{LiCl}, \mathrm{NaOH}$ or $\mathrm{KOH}$, is questionable. For these reasons, a new set of temperature-dependent interaction parameters for the $\mathrm{LiOH}-\mathrm{H}_{2} \mathrm{O}$ binary system is determined hereafter.

\subsubsection{Selection of experimental data}

Solution property data cover the aqueous solution domain in terms of molalities and temperatures better in the $\mathrm{LiOH}-\mathrm{H}_{2} \mathrm{O}$ binary system than in the $\mathrm{LiCl}-\mathrm{H}_{2} \mathrm{O}$ system (fig. 9). However, aqueous data is still lacking for the region near the solid-aqueous solution equilibrium 
at temperatures above $298.15 \mathrm{~K}$. They range from 0.1 to $5.0 \mathrm{~mol} / \mathrm{kg}$ for temperatures comprised between 298.15 and 363.15 K (Mikulin, 1968, Nasirzadeh and others, 2005). At $383.15 \mathrm{~K}$ (close to the temperature of $\mathrm{LiOH} \cdot \mathrm{H}_{2} \mathrm{O}(\mathrm{cr})$ to $\mathrm{LiOH}(\mathrm{cr})$ phase transition, see below), experimental data draw near to the solubility limit with osmotic coefficient values measured at molalities up to 7.2 mol/kg (Holmes and Mesmer, 1998a). These authors also provided aqueous properties at 413.12 and $443.09 \mathrm{~K}$ for molalities up to 5.6 and $5.1 \mathrm{~mol} / \mathrm{kg}$, respectively. No aqueous data are available at temperatures below $298.15 \mathrm{~K}$.

Solubility data from the compilations of Linke (1965) and Zdanovskii and others (1973) range from $273.15 \mathrm{~K}$ to $373.15 \mathrm{~K}$ and concern the equilibrium between the aqueous solution and the LiOH. $\mathrm{H}_{2} \mathrm{O}(\mathrm{cr})$ solid phase. At higher temperatures, solubility data for the $\mathrm{LiOH}(\mathrm{cr})$ solid phase are given by Itkina and others (1967). The phase transition point (382.05 K) between these two solid phases at equilibrium with the aqueous solution is given by Kirgintsev and others (1972). One inconsistent solubility point for $\mathrm{LiOH}_{2} \mathrm{H}_{2} \mathrm{O}(\mathrm{cr})$ at $273.15 \mathrm{~K}$ (Zdanovskii and others, 1973), is excluded from parameterization.

\subsubsection{Model parameterization}

Because Li hydroxides are moderately soluble (much less so than Li chlorides) and experimental aqueous properties show simple shapes in the $298.15-443.15 \mathrm{~K}$ temperature range, the binary $\mathrm{LiOH}-\mathrm{H}_{2} \mathrm{O}$ system can be described satisfactorily with the simple $\mathrm{Li}^{+}-\mathrm{OH}^{-}-\mathrm{H}_{2} \mathrm{O}$ chemical representation and the $\beta^{(0)}, \beta^{(1)}$, and $C^{\varphi}$ specific interaction parameters (table 2). The standard deviation $\sigma$ is 0.013 for the entire set of osmotic data (383 points) (fig. 10). The standard deviation $\sigma$ is 0.202 for the entire set of solubility data that are available from 273.15 up to $473.15 \mathrm{~K}$ (19 points) (fig. 11). Detailed $\sigma$ for the various data sets are given in table 1 . The monotonous behavior of the specific interaction parameters $\beta^{(0)}, \beta^{(1)}$, and $C^{\varphi}$ when plotted against 
temperature (fig. 12) is an indication of mathematical stability, and extrapolation to temperatures higher than $473.15 \mathrm{~K}$ could be done with relatively good confidence. Temperature functions for the $\mathrm{LiOH}(\mathrm{cr})$ and $\mathrm{LiOH} . \mathrm{H}_{2} \mathrm{O}(\mathrm{cr})$ solubility products were been determined during the fitting procedure (table 3) for the following chemical reactions where $\mathrm{n}=0$ or 1: $\mathrm{LiOH} \cdot n \mathrm{H}_{2} \mathrm{O}(\mathrm{cr})=\mathrm{Li}^{+}$ $+\mathrm{OH}^{-}+n \mathrm{H}_{2} \mathrm{O}$. For comparison, our equilibrium constants are plotted against temperature alongside those estimated by Monnin and Dubois (2005) (fig. 13). The two sets of values are in good agreement. However, a comparison of the calculated invariant points in the $\mathrm{LiOH}-\mathrm{H}_{2} \mathrm{O}$ system with experimental data (table 4) reveals a slight discrepancy. The calculated temperature transition between $\mathrm{LiOH}_{\mathrm{H}} \mathrm{H}_{2} \mathrm{O}(\mathrm{cr})$ and $\mathrm{LiOH}(\mathrm{cr})$ is $382.05 \mathrm{~K}$, whereas the experimental value reported by Kirgintsev and others (1972) in their compilation is $378.78 \mathrm{~K}$. This is due to the smoothing of the temperature function of the salt crystal solubility products.

The fitting procedure also provides an intrinsically consistent extrapolation of the osmotic coefficient for $\mathrm{LiOH}$ aqueous solutions down to $273.15 \mathrm{~K}$ and up to $473.15 \mathrm{~K}$ for which solubility data are available (fig. 10 ). $\mathrm{Li}^{+}$and $\mathrm{OH}^{-}$activity coefficients can, therefore, also be calculated with a good confidence at these temperatures. The mean activity coefficients of LiOH are compared to recommended values over the whole range of temperatures and molalities covered in the literature: from 273.15 to $523.15 \mathrm{~K}$ and from 0.1 to $5 \mathrm{~m}$ (table 6). Our calculated values fall between those recommended by Holmes and Mesmer (1998a) and by Nasirzadeh and others (2005) at 298.15 and $323.15 \mathrm{~K}$, for $\mathrm{LiOH}$ molalities ranging from 0.1 to $3 \mathrm{~m}$. At higher temperatures, our calculated values are in very good agreement with those of Holmes and Mesmer (1998a). Significant discrepancies appear at $273.15 \mathrm{~K}$ throughout the entire molality range because Holmes and Mesmer (1998a) were interested in the behavior of alkali aqueous solutions at high temperatures. On the other hand, our calculations are in good agreement with 
the recommended experimental deliquescence relative humidity and osmotic coefficient in the saturated LiOH binary system at $298.15 \mathrm{~K}$ (table 7 ). Our model provides even better results than the reference model of Pitzer and Mayorga (1973), the results of which are also shown in the table.

In mixed systems, parameterization of $\mathrm{LiOH}$ may be applied under conditions where the ionic strength of the aqueous mixtures is far greater than the values found along the solubility limit of $\mathrm{Li}$ hydroxides in the binary $\mathrm{Li}-\mathrm{OH}-\mathrm{H}_{2} \mathrm{O}$ system. For instance, this may occur in the ternary Li$\mathrm{Cl}-\mathrm{OH}-\mathrm{H}_{2} \mathrm{O}$ system, because of the high solubility of $\mathrm{Li}$ chlorides. The extended use of this parameterization is thought to be feasible only if it is stable, i.e. only if its behavior is relatively smooth and monotonous with respect to salinity. We therefore verified this for various temperatures ranging from 273.15 to $473.15 \mathrm{~K}$ (fig. 14).

\subsection{Ternary $\mathrm{LiCl}-\mathrm{LiOH}-\mathrm{H}_{2} \mathrm{O}$ and $\mathrm{LiCl}-\mathrm{HCl}-\mathrm{H}_{2} \mathrm{O}$ Systems}

\subsubsection{Selection of experimental data}

Solution property data are rare for ternary systems. Only two sets are available at 273.15 and 323.15 K (Chernyh and others, 1987) for the $\mathrm{LiCl}-\mathrm{LiOH}-\mathrm{H}_{2} \mathrm{O}$ ternary system (fig. 15A). At 323.15 K, experimental data show a very complex lithium solubility behavior at very high concentrations. These authors suggest that the existence of double salts, such as $\mathrm{LiCl} .3 \mathrm{LiOH}(\mathrm{cr})$ and $\mathrm{LiCl} . \mathrm{LiOH}(\mathrm{cr})$, might control this solubility.

Three sets of solubility data are also available for the $\mathrm{LiCl}-\mathrm{HCl}-\mathrm{H}_{2} \mathrm{O}$ ternary system, at 273.15 (Engel, 1888, Chu and Zai, 1965), 293.15 (Li and others, 2000) and 298.15 K (Herz, 1912) and for relatively limited ranges of salinities (fig. 16). Data at 273.15 and $298.15 \mathrm{~K}$ come from the compilation of Zdanovskii and others (1973). Chu and Zai (1965) give the composition of the 
aqueous solution at the eutonic point at $273.15 \mathrm{~K}$, where $\mathrm{LiCl}_{2} \mathrm{H}_{2} \mathrm{O}(\mathrm{cr})$ and $\mathrm{LiCl}_{2} 2 \mathrm{H}_{2} \mathrm{O}$ (cr) coexist: $8.253 \mathrm{~m} \mathrm{LiCl}+11.736 m \mathrm{HCl}$.

Despite the scarcity of experimental data, these two ternary systems must be considered so that the $\mathrm{pH}$ can be taken into account when dealing with natural or industrial Li-containing brines.

\subsubsection{Model parameterization}

In order to be able to add Li to the existing Christov and Møller (2004a, b) model, the ternaryspecific interaction parameter $\theta$ for the $\left(\mathrm{OH}^{-}, \mathrm{Cl}^{-}\right)$couple must be the same as the one proposed by these authors. The description of the $\mathrm{Li}-\mathrm{OH}-\mathrm{Cl}-\mathrm{H}_{2} \mathrm{O}$ system therefore only requires fitting of the binary $\lambda_{\mathrm{OH}-\mathrm{LiCl}}$ and of the ternary $\psi_{\mathrm{Li}-\mathrm{OH}-\mathrm{Cl}}$, and $\zeta_{\mathrm{Li}-\mathrm{OH}-\mathrm{LiCl}}$ interaction parameters. The best results that could be obtained with the constraint on $\theta_{\mathrm{OH}-\mathrm{Cl}}$ were plotted (fig. $15 \mathrm{~A}$ ) and are, as expected, more satisfying at $293.15 \mathrm{~K}$ than at $323.15 \mathrm{~K}$, with $\sigma$ values of 0.101 and 0.122 , respectively. At $323.15 \mathrm{~K}$, the model was not able to reproduce the data points corresponding to the assumed LiCl.LiOH(cr) - solution equilibrium and are not included in the calculated standard deviation. On the other hand, the best results for salt-solution equilibrium in this composition domain were obtained with a hypothetical $3 \mathrm{LiCl} \cdot \mathrm{LiOH}(\mathrm{cr})$ double salt rather than with the $\mathrm{LiCl} . \mathrm{LiOH}(\mathrm{cr})$ double salt as suggested by Chernyh and others (1987). At this stage, there is not enough information to settle the issue. The calculated solubility product of the double salt 3 $\mathrm{LiCl} . \mathrm{LiOH}(\mathrm{cr})$ is $\log \mathrm{K}_{\mathrm{sp}}=17.95$ at $323.15 \mathrm{~K}$, for the dissolution reaction: $3 \mathrm{LiCl} \cdot \mathrm{LiOH}(\mathrm{cr})=4$ $\mathrm{Li}^{+}(\mathrm{aq})+3 \mathrm{Cl}^{-}(\mathrm{aq})+\mathrm{OH}^{-}(\mathrm{aq})$.

Specific interaction parameters were extrapolated up to $523.15 \mathrm{~K}$ so that solubility calculations could be done at least between 273.15 and $323.15 \mathrm{~K}$. In particular, we can plot the behavior of the system at $298.15 \mathrm{~K}$ as suggested in figure $17 \mathrm{~B}$, where the composition of the solution is controlled mainly by $\mathrm{LiOH} . \mathrm{H}_{2} \mathrm{O}(\mathrm{cr})$ and $\mathrm{LiCl} . \mathrm{H}_{2} \mathrm{O}(\mathrm{cr})$ salts. Only a small domain could be 
controlled by $\mathrm{LiOH}(\mathrm{cr})$. The specific interaction parameters (table 8) were plotted against temperature (fig. 17). $\psi_{\mathrm{Li}-\mathrm{OH}-\mathrm{Cl}}$ is almost constant with temperature and has been extrapolated linearly to $523.15 \mathrm{~K}$. On the other hand, $\lambda_{\mathrm{OH}-\mathrm{LiCl}}$ and $\zeta_{\mathrm{Li}-\mathrm{OH}-\mathrm{LiCl}}$ are much more temperaturesensitive. They have been extrapolated here to $523.15 \mathrm{~K}$ assuming they are nil at this temperature.

Description of the $\mathrm{Li}-\mathrm{H}-\mathrm{Cl}-\mathrm{H}_{2} \mathrm{O}$ system requires fitting of the $\theta_{\mathrm{Li}-\mathrm{H}}, \psi_{\mathrm{Li}-\mathrm{H}-\mathrm{Cl}}$, and $\zeta_{\mathrm{H}-\mathrm{Cl}-\mathrm{LiCl}}$ ternary interaction parameters. The $\zeta_{\mathrm{H}-\mathrm{Cl}-\mathrm{LiCl}}$ parameter did not seem to be needed and was set at 0 . The fitting of $\theta_{\mathrm{Li}-\mathrm{H}}$ and $\psi_{\mathrm{Li}-\mathrm{H}-\mathrm{Cl}}$ leads to a good simulation of experimental data (fig. 16), with $\sigma$ values of 0.039 at $273.15 \mathrm{~K}, 0.022$ at $293.15 \mathrm{~K}$, and 0.101 at $298.15 \mathrm{~K}$. The high $\sigma$ value at $298.15 \mathrm{~K}$ is due to the relative dispersion of the experimental data points. $\theta_{\mathrm{Li}-\mathrm{H}}$ and $\psi_{\mathrm{Li}-\mathrm{H}-\mathrm{Cl}}$ vary only slightly with temperature and were extrapolated linearly up to about $400 \mathrm{~K}$ (fig. 18 and table 8), suggesting the plotted behavior of the $\mathrm{LiCl}(\mathrm{cr})-\mathrm{HCl}$ solution equilibrium at $373.15 \mathrm{~K}$ (fig. 16).

\subsection{Ternary $\mathrm{LiCl}-\mathrm{KCl}-\mathrm{H}_{2} \mathrm{O}$ System}

\subsubsection{Selection of experimental data}

Few solution property data exist for this ternary system. El Guendouzi and others (2003) provide osmotic coefficients, measured at $298.15 \mathrm{~K}$ with the hygroscopic method, for aqueous solutions with total $\mathrm{Cl}$ molalities ranging from 0.3 to $6 \mathrm{~mol} / \mathrm{kg}$ and $\mathrm{Li} / \mathrm{K}$ ratios of 1/2, 1/1, and 2/1 (fig. 19). More abundant information exists concerning solubility measurements, describing mixtures of $\mathrm{LiCl}$ and $\mathrm{KCl}$ electrolytes from 0 to $100 \%$ for temperatures comprised between 273.15 and 373.15 K (Campbell and Kartzmark, 1956, Plyushchev and others, 1959, Akopov, 1962, Yanko and Goldanel, 1964, in Zdanovskii and others, 1973). These solubility data were plotted to show the phase diagram at low temperatures (at 273.15 and $283.15 \mathrm{~K}$ ), involving the $\mathrm{LiCl} .2 \mathrm{H}_{2} \mathrm{O}$ (cr) and $\mathrm{KCl}(\mathrm{cr})$ (sylvite) mineral phases (fig. 20A), the phase diagram involving the $\mathrm{LiCl} \cdot \mathrm{H}_{2} \mathrm{O}(\mathrm{cr}$ ) 
and $\mathrm{KCl}(\mathrm{cr})$ mineral phases for temperatures ranging from 298.15 to $348.15 \mathrm{~K}$ (Fig. 20B), and the phase diagram at $373.15 \mathrm{~K}$ involving the $\mathrm{LiCl}(\mathrm{cr})$ and $\mathrm{KCl}(\mathrm{cr})$ mineral phases (fig. 20C). These data show that pure phases control the dissolved species concentrations (no double salt). For each temperature, we can identify an invariant point that defines the coexistence of a pure Li-bearing chloride with a pure K-bearing chloride (for example sylvite). However, two sets of data, at 303.15 and $313.15 \mathrm{~K}$ (Blidin, 1953) are inconsistent with such behavior and are therefore not used for parameterization. Four other data points (at 273.15, 283.15, 298.15, and 323.15 K) are also removed because of inconsistency with the rest of the dataset.

Experimental solubility data show that regardless of the temperature, increasing the $\mathrm{LiCl}$ content in a $\mathrm{KCl}$ aqueous solution decreases the solubility of sylvite down to a minimum, which decreases as the temperature decreases. Thereafter, a further increase in the dissolved $\mathrm{LiCl}$ content destabilizes sylvite once again. Conversely, an increase in the $\mathrm{KCl}$ content in a $\mathrm{LiCl}$ aqueous solution does not significantly modify or only slightly increases the solubility of the LiCl. $n \mathrm{H}_{2} \mathrm{O}$ salts $(n=0,1$, or 2 depending on the temperature).

\subsubsection{Model parameterization}

After the parameters for the binary $\mathrm{LiCl}-\mathrm{H}_{2} \mathrm{O}$ and $\mathrm{KCl}-\mathrm{H}_{2} \mathrm{O}$ systems have been determined, the ternary interaction parameters (namely, $\lambda_{\mathrm{K}-\mathrm{LiCl}}, \zeta_{\mathrm{K}-\mathrm{Cl}-\mathrm{LiCl}}, \theta_{\mathrm{Li}-\mathrm{K}}$ and $\psi_{\mathrm{Li}-\mathrm{K}-\mathrm{Cl}}$ ) for the $\mathrm{LiCl}-\mathrm{KCl}-\mathrm{H}_{2} \mathrm{O}$ can be fitted. The $\theta_{\mathrm{Li}-\mathrm{K}}$ interaction parameter is common to the two ternary systems of interest involving $\mathrm{K}$ (namely $\mathrm{LiCl}-\mathrm{KCl}-\mathrm{H}_{2} \mathrm{O}$ and $\mathrm{LiOH}-\mathrm{KOH}-\mathrm{H}_{2} \mathrm{O}$ ). We preferred fitting it from the $\mathrm{LiCl}-\mathrm{KCl}-\mathrm{H}_{2} \mathrm{O}$ system, for which data are more abundant. Interaction parameters resulting from the fitting procedure (table 8) were plotted (fig. 21). As experimental solubility data are limited to temperatures below $373.15 \mathrm{~K}$, a particular effort was made to obtain smooth functions with respect to temperature in order to be able to extrapolate above $373.15 \mathrm{~K}$ with relative confidence. 
The solubility product of sylvite is taken from Greenberg and Møller (1989), but the parameters have been adjusted (table 3 ) in order to be consistent with equation (1).

The hygroscopic data for activity of water measured by El Guendouzi and others (2003) provided useful additional constraints at $298.15 \mathrm{~K}$ and moderate salinity in the mixed solution (fig. 19). Both the overall $\sigma$ value (table 1) and the results for mineral solubility (fig. 20) indicate that calculated solubility is in good agreement with experimental data. The position of the $\mathrm{LiCl} .2 \mathrm{H}_{2} \mathrm{O}(\mathrm{cr})-\mathrm{KCl}(\mathrm{cr})$ and $\mathrm{LiCl} \cdot \mathrm{H}_{2} \mathrm{O}(\mathrm{cr})-\mathrm{KCl}(\mathrm{cr})$ invariant points, in particular, are correctly predicted (fig. 20A and B). At $373.15 \mathrm{~K}$, however, there is a significant discrepancy between the predicted and the experimental $\mathrm{LiCl}(\mathrm{cr})-\mathrm{KCl}(\mathrm{cr})$ invariant point (fig. 20C). Indeed, the calculated molality of dissolved $\mathrm{KCl}$ at this point is $4.96 \mathrm{~mol} / \mathrm{kg}$, whereas the measured value is 4.52 $\mathrm{mol} / \mathrm{kg}$. On the other hand, the calculated molality of dissolved $\mathrm{LiCl}$ is $31.40 \mathrm{~mol} / \mathrm{kg}$ for a measured value of $31.49 \mathrm{~mol} / \mathrm{kg}$.

The discrepancy obtained for the $\mathrm{KCl}$ concentration at the invariant point at $373.15 \mathrm{~K}$ is due to the fact that the interaction parameters for the binary $\mathrm{KCl}-\mathrm{H}_{2} \mathrm{O}$ system are taken from Greenberg and Møller (1989), who fitted the relevant parameters using the isopiestic experimental data from Holmes and others (1978) and Holmes and Mesmer (1983). In these studies, $\mathrm{KCl}$ molalities were comprised between 0.005 and $8.5 \mathrm{~mol} / \mathrm{kg}$, i.e. up to saturation for sylvite at high temperature. Greenberg and Møller (1989) showed that their model is valid up to a $\mathrm{KCl}$ molality of $11 \mathrm{~mol} / \mathrm{kg}$ at $473.15 \mathrm{~K}$. However, the ionic strength at the $\mathrm{LiCl}(\mathrm{cr})-\mathrm{KCl}(\mathrm{cr})$ invariant point reaches 23.0 eq $/ \mathrm{kg}$ at $373.15 \mathrm{~K}$, which is much higher than the validated domain of application of the Greenberg and Møller (1989) model. Our results show, however, that the parameterization of these authors for the $\mathrm{KCl}-\mathrm{H}_{2} \mathrm{O}$ binary system is stable enough so that its use can be reasonably extended to highly saline ternary systems. 


\subsection{Ternary $\mathrm{LiCl}-\mathrm{NaCl}-\mathrm{H}_{2} \mathrm{O}$ System}

\subsubsection{Selection of experimental data}

Like for the $\mathrm{LiCl}-\mathrm{KCl}-\mathrm{H}_{2} \mathrm{O}$ system, few solution property data exist for this ternary system. These are osmotic coefficients, measured by El Guendouzi and others (2004) using the hygroscopic method, at $298.15 \mathrm{~K}$. Total $\mathrm{Cl}$ molalities in experimental aqueous solutions range between 0.3 and $6 \mathrm{~mol} / \mathrm{kg}$ for $\mathrm{Li} / \mathrm{K}$ ratios of 1/2,1/1, and 2/1 (fig. 22). Solubility measurements describing mixtures of $\mathrm{LiCl}$ and $\mathrm{NaCl}$ electrolytes from 0 to $100 \%$ for temperatures comprised between 273.15 and $373.15 \mathrm{~K}$ were compiled by Zdanovskii and others (1973). Our selected experimental data are from Akopov (1963) at 273.15 K, and from Khy (1960) at 298.15, 323.15, 363.15, and 373.15 K (fig. 23). They show that pure phases control the concentrations of dissolved species (no double salt). For each temperature, we can identify an invariant point that defines the coexistence of a pure Li-bearing chloride with a pure Na-bearing chloride (namely, halite, $\mathrm{NaCl}$ ). However, several sets of data, at 298.15, 313.15, 323.15, and 363.15 K (Smits and others, 1924, Blidin, 1953, Kindyakov and others, 1958) are inconsistent with such a behavior and are therefore not used for parameterization. One data point (from Khy, 1960, at $323.15 \mathrm{~K}$ ) was not used because of inconsistency with the rest of the dataset.

Like in the $\mathrm{LiCl}-\mathrm{KCl}-\mathrm{H}_{2} \mathrm{O}$ system, experimental solubility data show that regardless of the temperature, increasing the $\mathrm{LiCl}$ content in a $\mathrm{NaCl}$ aqueous solution decreases halite solubility. The difference here is that the minimum solubility of halite $(<0.4 \mathrm{~m} \mathrm{NaCl}$ at $373.15 \mathrm{~K})$ is much lower than that of sylvite (> $1.5 \mathrm{~m} \mathrm{KCl}$ at $373.15 \mathrm{~K}$ ). Moreover, a further increase in the dissolved $\mathrm{LiCl}$ content does not further destabilize halite, or only very slightly. An increase in the $\mathrm{NaCl}$ content in a $\mathrm{LiCl}$ aqueous solution does not modify the solubility of the $\mathrm{LiCl} \cdot n \mathrm{H}_{2} \mathrm{O}$ (cr) salts ( $n=0,1$, or 2 depending on the temperature) until the invariant point is reached. 


\subsubsection{Model parameterization}

The ternary interaction parameters to be determined here are $\lambda_{\mathrm{Na}-\mathrm{LiCl}}, \zeta_{\mathrm{Na}-\mathrm{Cl}-\mathrm{LiCl}}, \theta_{\mathrm{Li}-\mathrm{Na}}$ and $\psi_{\mathrm{Li}-\mathrm{Na}-\mathrm{Cl}}$, The $\theta_{\mathrm{Li}-\mathrm{Na}}$ interaction parameter is common to the two ternary systems, $\mathrm{LiCl}-\mathrm{NaCl}-\mathrm{H}_{2} \mathrm{O}$ and $\mathrm{LiOH}-\mathrm{NaOH}-\mathrm{H}_{2} \mathrm{O}$. We preferred fitting it from the $\mathrm{LiCl}-\mathrm{NaCl}-\mathrm{H}_{2} \mathrm{O}$ system for which data are more abundant. Interaction parameters resulting from the fitting procedure (table 8) were plotted (fig. 24). As experimental solubility data are limited up to a temperature of $373.15 \mathrm{~K}$, an effort was made to obtain smooth functions with respect to temperature to enable extrapolation above $373.15 \mathrm{~K}$ with relative confidence. In particular, $\lambda_{\mathrm{Na}-\mathrm{LiCl}}$ and $\psi_{\mathrm{Li}-\mathrm{Na}-\mathrm{Cl}}$ vary linearly with temperature. The solubility product of halite (table 3) is taken from Thermoddem (Blanc and others, 2012) after the standard enthalpy and entropy suggested by Chase (1998) and the heat capacity given by Helgeson and others (1978).

Results for osmotic coefficients and minerals solubility were plotted (fig. 22 and 23). Both the overall $\sigma$ value (table 1) and figure 23 show that calculated solubility is in good agreement with experimental data. In particular, the position of the $\mathrm{LiCl} .2 \mathrm{H}_{2} \mathrm{O}(\mathrm{cr})-\mathrm{NaCl}(\mathrm{cr}), \mathrm{LiCl} \cdot \mathrm{H}_{2} \mathrm{O}(\mathrm{cr})-$ $\mathrm{NaCl}(\mathrm{cr})$ and $\mathrm{LiCl}(\mathrm{cr})-\mathrm{NaCl}(\mathrm{cr})$ invariant points are correctly predicted (fig. 23B). For temperatures above $273.15 \mathrm{~K}$ and $\mathrm{LiCl}$ concentrations below $12 \mathrm{M}$, the accuracy of our model is comparable to that of the recent Pitzer model of Dubois and others (2010). Nevertheless, thanks to the use of the $\operatorname{LiCl}^{0}$ (aq) aqueous species, our model is stable enough to allow the description of the behavior of the ternary $\mathrm{LiCl}-\mathrm{NaCl}-\mathrm{H}_{2} \mathrm{O}$ system beyond the limit of $12 \mathrm{M} \mathrm{LiCl}$, up to the solubility of the different crystal hydrates of lithium chloride.

\subsection{Quaternary LiCl- $\mathrm{NaCl}-\mathrm{KCl}-\mathrm{H}_{2} \mathrm{O}$ System}

Yanatieva (1947) and Campbell and Kartzmark (1956) measured the composition of brines in the Li-Na-K-Cl- $\mathrm{H}_{2} \mathrm{O}$ system along the halite-sylvite equilibrium line up to the invariant point, 
corresponding to the additional equilibrium with $\mathrm{LiCl} . n \mathrm{H}_{2} \mathrm{O}(\mathrm{cr})$, where $n=2$ at $\mathrm{T}=273.15 \mathrm{~K}$ and $n=1$ at $\mathrm{T}=298.15$ and $323.15 \mathrm{~K}$. For each of these experimentally measured compositions, we calculated the saturation indices of the observed salts. They are plotted on figure 25 as a function of the dissolved $\mathrm{Li}$ content relative to the total aqueous $\mathrm{Cl}$ content $(\mathrm{Li} / \mathrm{Cl}=1$ represents the binary $\mathrm{Li}-\mathrm{Cl}-\mathrm{H}_{2} \mathrm{O}$ system; $\mathrm{Li} / \mathrm{Cl}=0$ represents the ternary $\mathrm{Na}-\mathrm{K}-\mathrm{Cl}-\mathrm{H}_{2} \mathrm{O}$ system). These quantities, which are widely used in geochemical modeling, are convenient for evaluating the gap between the actual state of the system (aqueous solution + mineral) and the theoretical thermodynamic equilibrium since they are defined on an energy basis rather than on a concentration basis. Indeed, given the dissolution reaction of a mineral, the saturation index of the mineral is defined, in log units, by the ratio of the ion activity product versus the solubility product. The ion activity product represents the actual state of the aqueous solution while the solubility product is the expected value of the ion activity product at equilibrium. Moreover saturation indices can help identifying the chemical sub-system(s) for which the model should be improved. Null saturation indices indicate that the aqueous solution and the mineral under consideration are at thermodynamic equilibrium. The saturation indices show that, in agreement with experimental observations, halite and sylvite are close to equilibrium with the brines (fig. 25). However, there are significant discrepancies for some compositions. This concerns mostly halite near or at the invariant point, regardless of the temperature. It is difficult here to clearly identify whether these discrepancies are caused by experimental errors or are inherent to the model but, in any case, these results are satisfactory and confirm that our model can be applied to complex systems. 


\subsection{Ternary LiOH- $\mathrm{KOH}-\mathrm{H}_{2} \mathrm{O}$ System}

\subsubsection{Selection of experimental data}

Literature data for this ternary system, in the temperature and concentration ranges of interest, are scarcer than for the $\mathrm{LiCl}-\mathrm{KCl}-\mathrm{H}_{2} \mathrm{O}$ system. They are limited to solubility data measured at 323.15, 373.15, and 423.15 K (Itkina and others, 1967, 1968), and describe mixtures of LiOH and $\mathrm{KOH}$ electrolytes ranging from 0 to $100 \%$ (fig. 26A and $\mathrm{B}$ ). These experimental data suggest that pure phases control the dissolved species concentrations, and invariant points can be identified, defining conditions of coexistence of two pure phases at equilibrium with the aqueous solution. It also seems that there is no stability domain for mixed crystals or double salts in the systems under consideration in this study.

\subsubsection{Model parameterization}

To describe the behavior of the mixed $\mathrm{LiOH}-\mathrm{KOH}-\mathrm{H}_{2} \mathrm{O}$ system, the $\theta_{\mathrm{Li}-\mathrm{K}}$ and $\psi_{\mathrm{Li}-\mathrm{K}-\mathrm{OH}}$ specific interaction parameters are required, in addition to parameters and solubility products determined for the binary $\mathrm{LiOH}-\mathrm{H}_{2} \mathrm{O}$ and $\mathrm{KOH}-\mathrm{H}_{2} \mathrm{O}$ systems. The $\theta_{\mathrm{Li}-\mathrm{K}}$ cation-cation interaction parameter was fitted previously for the $\mathrm{LiCl}-\mathrm{KCl}-\mathrm{H}_{2} \mathrm{O}$ mixed system $(\S 3.4)$. Therefore, there is only one temperature-dependent parameter to be fitted in this section: $\psi_{\mathrm{Li}-\mathrm{K}-\mathrm{OH}}$. The equilibrium constant of the $\mathrm{KOH} . \mathrm{H}_{2} \mathrm{O}(\mathrm{cr})$ mineral phase is also needed here and is adapted from Christov and Møller (2004b).

Resulting mineral-solution equilibrium functions compare relatively well with experimental data (fig. 26A and B). The overall absolute deviation is 0.0964 for 18 data. This indicates that the $\theta_{\mathrm{Li}-}$ $\mathrm{K}$ parameter determined in $(\S 3.4)$ is also well suited here. The temperature function for the $\psi_{\mathrm{Li}-\mathrm{K} \text { - }}$ OH interaction parameter (table 8) was plotted (fig. 27). 
Significant discrepancies can however be observed concerning the location of the invariant points at 323.15 and $373.15 \mathrm{~K}$ (fig. $26 \mathrm{~A}$ and B). At $323.15 \mathrm{~K}$, the calculated $\mathrm{LiOH}(\mathrm{cr}$ )LiOH. $\mathrm{H}_{2} \mathrm{O}(\mathrm{cr})$ invariant point is located at $\mathrm{m}(\mathrm{KOH})=12.44 \mathrm{~mol} / \mathrm{kg}$ and $\mathrm{m}(\mathrm{LiOH})=1.49$ $\mathrm{mol} / \mathrm{kg}$. For comparison, the experimental point is located at $\mathrm{m}(\mathrm{KOH})=14.38 \mathrm{~mol} / \mathrm{kg}$ and $\mathrm{m}(\mathrm{LiOH})=0.98 \mathrm{~mol} / \mathrm{kg}$. The calculated $\mathrm{LiOH}(\mathrm{cr})-\mathrm{KOH} \cdot \mathrm{H}_{2} \mathrm{O}(\mathrm{cr})$ invariant point is located at $\mathrm{m}(\mathrm{KOH})=25.9 \mathrm{~mol} / \mathrm{kg}$ and $\mathrm{m}(\mathrm{LiOH})=0.36 \mathrm{~mol} / \mathrm{kg}$, whereas the experimental equivalent is located at $\mathrm{m}(\mathrm{KOH})=25.09 \mathrm{~mol} / \mathrm{kg}$ and $\mathrm{m}(\mathrm{LiOH})=0.70 \mathrm{~mol} / \mathrm{kg}$. At $373.15 \mathrm{~K}$, the calculated $\mathrm{LiOH}(\mathrm{cr})-\mathrm{LiOH} . \mathrm{H}_{2} \mathrm{O}(\mathrm{cr})$ invariant point is located at $\mathrm{m}(\mathrm{KOH})=3.2 \mathrm{~mol} / \mathrm{kg}$ and $\mathrm{m}(\mathrm{LiOH})=5.23$ $\mathrm{mol} / \mathrm{kg}$, whereas the experimental equivalent is located at $\mathrm{m}(\mathrm{KOH})=4.42 \mathrm{~mol} / \mathrm{kg}$ and $\mathrm{m}(\mathrm{LiOH})$ $=4.12 \mathrm{~mol} / \mathrm{kg}$. The calculated $\mathrm{LiOH}(\mathrm{cr})-\mathrm{KOH} \cdot \mathrm{H}_{2} \mathrm{O}(\mathrm{cr})$ invariant point is located at $\mathrm{m}(\mathrm{KOH})=$ $30.33 \mathrm{~mol} / \mathrm{kg}$ and $\mathrm{m}(\mathrm{LiOH})=0.47 \mathrm{~mol} / \mathrm{kg}$ whereas the experimental equivalent is located at $\mathrm{m}(\mathrm{KOH})=36.99 \mathrm{~mol} / \mathrm{kg}$ and $\mathrm{m}(\mathrm{LiOH})=1.39 \mathrm{~mol} / \mathrm{kg}$. As we did for the $\mathrm{K}^{+}-\mathrm{Cl}^{-}$binary interactions parameters in the $\mathrm{LiCl}-\mathrm{KCl}-\mathrm{H}_{2} \mathrm{O}$ mixed system, we determined the $\mathrm{Li}^{+}-\mathrm{OH}^{-}$binary interaction parameters using experimental data of the binary $\mathrm{LiOH}-\mathrm{H}_{2} \mathrm{O}$ system up to the solubility of the related minerals, namely up to a maximum ionic strength of $8 \mathrm{eq} / \mathrm{kg}$. The ionic strengths encountered in the $\mathrm{LiOH}-\mathrm{KOH}-\mathrm{H}_{2} \mathrm{O}$ mixed system are much higher. Therefore, the $\mathrm{Li}^{+}-$ $\mathrm{OH}^{-}$binary interaction parameters may not be fully optimized to deal with the $\mathrm{LiOH}-\mathrm{KOH}-\mathrm{H}_{2} \mathrm{O}$ mixed system. However, two things prevent us from trying to improve our parameterization. Firstly, the scarcity of experimental data would impose too few constraints on the fitting procedure, and secondly, interaction parameters for the $\mathrm{KOH}-\mathrm{H}_{2} \mathrm{O}$ binary system given by Christov and Møller (2004b) are validated for temperatures between 273.15 and $443.15 \mathrm{~K}$ based on experimental aqueous data up to a $\mathrm{KOH}$ molality of $5 \mathrm{~mol} / \mathrm{kg}$ (Holmes and Mesmer, 1998a), 
and the solubility of the $\mathrm{KOH} \cdot \mathrm{H}_{2} \mathrm{O}(\mathrm{cr})$ mineral phase up to $343.15 \mathrm{~K}$. Reviewing the parameterization of this last binary chemical system is beyond the scope of our study.

Phase diagrams of the $\mathrm{LiOH}-\mathrm{KOH}-\mathrm{H}_{2} \mathrm{O}$ system have, nevertheless, been extrapolated to 273.15 , 298.15 and $473.15 \mathrm{~K}$ (fig. 26C). Results suggest that the two $\mathrm{LiOH} \cdot \mathrm{H}_{2} \mathrm{O}(\mathrm{cr})-\mathrm{LiOH}(\mathrm{cr})$ and $\mathrm{LiOH}(\mathrm{cr})-\mathrm{KOH}(\mathrm{cr})$ invariant points may still exist at $298.15 \mathrm{~K}$. At $273.15 \mathrm{~K}$, the $\mathrm{LiOH}(\mathrm{cr})$ stability domain would no longer exist in favor of the $\mathrm{LiOH} . \mathrm{H}_{2} \mathrm{O}(\mathrm{cr})$ and $\mathrm{KOH} . \mathrm{H}_{2} \mathrm{O}(\mathrm{cr})$ minerals, the coexistence of which would define a new invariant point. At $473.15 \mathrm{~K}$, calculations suggest that, in agreement with experimental observations (Itkina and others, 1967), only the LiOH(cr) mineral phase could be at equilibrium with the aqueous solution, at least up to a $\mathrm{KOH}$ molality of $25 \mathrm{~mol} / \mathrm{kg}$. This is also the case at $423.15 \mathrm{~K}$ (fig. 26B).

\subsection{Ternary $\mathrm{LiOH}-\mathrm{NaOH}-\mathrm{H}_{2} \mathrm{O}$ System}

\subsubsection{Selection of experimental data}

Literature data for this ternary system are much scarcer than for the other ternary systems considered here. They are exclusively solubility data that have been measured at 303.15 (Evteeva, 1965) and 423.15 K (Itkina and others, 1968) (fig. 28A and B). These experimental data suggest that pure phases control the concentrations of dissolved species in the range of concentrations where experimental data are available. Invariant points are not clearly defined, and it seems that there is no stability domain for mixed crystals or double salts. Additional experimental solubility data are also shown (fig. 28A and B) for the binary $\mathrm{LiOH}_{-} \mathrm{H}_{2} \mathrm{O}(\mathrm{Linke}$, 1965 ) and $\mathrm{NaOH}-\mathrm{H}_{2} \mathrm{O}$ (see data selection of Christov and Møller, 2004b) systems.

\subsubsection{Model parameterization}

To describe the behavior of the mixed $\mathrm{LiOH}-\mathrm{NaOH}-\mathrm{H}_{2} \mathrm{O}$ system, the $\theta_{\mathrm{Li}-\mathrm{Na}}$ and $\psi_{\mathrm{Li}-\mathrm{Na}-\mathrm{OH}}$ specific interaction parameters are required in addition to the parameters and solubility products 
determined for the binary $\mathrm{LiOH}-\mathrm{H}_{2} \mathrm{O}$ and $\mathrm{NaOH}-\mathrm{H}_{2} \mathrm{O}$ systems. The $\theta_{\mathrm{Li}-\mathrm{Na}}$ cation-cation interaction parameter was fitted for the $\mathrm{LiCl}-\mathrm{NaCl}-\mathrm{H}_{2} \mathrm{O}$ mixed system $(\S 3.4)$. Therefore, there is only one temperature-dependent parameter to be fitted in this section: $\psi_{\mathrm{Li}-\mathrm{Na}-\mathrm{OH}}$. The equilibrium constants of the $\mathrm{NaOH} . \mathrm{H}_{2} \mathrm{O}(\mathrm{cr})$ and $\mathrm{NaOH} .4 \mathrm{H}_{2} \mathrm{O}$ (cr) mineral phases are also needed here. They are taken from Christov and Møller (2004b).

The resulting mineral-solution equilibrium functions (fig. 28A and B) compare relatively well with experimental data. The overall absolute deviation is 0.1081 for 22 data. This indicates that the $\theta_{\text {Li-Na }}$ parameter determined in paragraph 3.5 is relatively well suited here. The temperature function for the $\psi_{\mathrm{Li}-\mathrm{Na}-\mathrm{OH}}$ interaction parameter (table 8) was plotted (fig. 27). The model is limited by minerals solubility at temperatures lower than $323.15 \mathrm{~K}$, and to $\mathrm{NaOH}$ molalities of $20 \mathrm{~m}$ above this temperature.

\section{SUMMARY AND RECOMMENDATIONS}

A parameterization procedure for models based on Pitzer formalism for binary electrolyte systems with at least one univalent ion was developed in order to select those best suited for binary systems. This involves developing models as simple as possible, and then increasing their complexity while seeking accuracy. The suitability of the models accepted for binary systems is then confirmed by the development of accurate models for higher order mixed systems.

Two binary and six ternary systems were studied using this procedure within the framework of the Pitzer formalism: $\mathrm{LiCl}-\mathrm{H}_{2} \mathrm{O}, \mathrm{LiOH}-\mathrm{H}_{2} \mathrm{O}$, $\mathrm{LiCl}-\mathrm{LiOH}-\mathrm{H}_{2} \mathrm{O}, \mathrm{LiCl}-\mathrm{HCl}-\mathrm{H}_{2} \mathrm{O}, \mathrm{LiCl}-\mathrm{KCl}-\mathrm{H}_{2} \mathrm{O}$, LiCl-NaCl- $\mathrm{H}_{2} \mathrm{O}$, LiOH-KOH- $\mathrm{H}_{2} \mathrm{O}$, LiOH-NaOH- $\mathrm{H}_{2} \mathrm{O}$ systems. We propose a new Pitzer parameterization that enables us to describe the excess properties of aqueous solutions (osmotic coefficient, activity of water, activity coefficients) and minerals solubility for a wide range of 
concentrations and temperatures. Our study, like others (Christov and Møller, 2004b, Lassin and others, 2009), clearly shows that the standard Pitzer formalism (using the $\beta^{(0)}, \beta^{(1)}$, and $C^{\varphi}$ interaction parameters) is able to describe mineral-solution systems up to very high salinities (40 $\mathrm{mol} / \mathrm{kg}$, for the binary $\mathrm{LiCl}-\mathrm{H}_{2} \mathrm{O}$ system) and temperatures $(523.15 \mathrm{~K})$. For this binary system, however, the neutral ion pair $\mathrm{LiCl}^{0}$ (aq) must be added to cover the entire range of concentrations and temperatures of interest. A four-interaction parameter Pitzer model (using an additional $\beta^{(2)}$ parameter) is also proposed. Using constant $\alpha_{1}$ and $\alpha_{2}$ parameters, the range of application of this model is limited to temperatures and salinities lower than $485 \mathrm{~K}$ and $37 \mathrm{~mol} / \mathrm{kg}$ of $\mathrm{LiCl}$, respectively.

Whereas Christov and Møller (2004b) have already well described the complex H-Na-K-Cl-OH$\mathrm{H}_{2} \mathrm{O}$ system up to mineral solubility and high temperatures, our work makes it possible to extend the application to the $\mathbf{H}-\mathbf{L i}-\mathbf{N a}-\mathbf{K}-\mathbf{C l}-\mathbf{O H}-\mathbf{H}_{2} \mathrm{O}$ system, including mineral-solution equilibria, up to high salinities and high temperatures.

The salinity and temperature limits for the application of this model will depend on the chemical elements actually present. However, this is primarily due to the lack of experimental data that are needed to better constrain the model under extreme conditions in order to improve and/or extend its domain of validity. In particular, it would be of interest to include additional commonly occurring cations such as magnesium and calcium, and anions such as sulfates in the model.

This work is the essential first step to tentatively describing lithium behavior in saline natural environments, and highlights a real need for additional experimental data. 


\section{ACKNOWLEDGEMENTS}

This work was funded by the ANR (French National Agency of Research via the Carnot Institute funds) and by the Research Direction of BRGM. The work of C. Christov was also partly funded by the National Science Fund of the Bulgarian Ministry of Science and Education (Grant No. DO 02-243). A. Lassin is grateful to Valérie Montouillout for instructive NMR measurements and to Anne-Laure Rollet, Jean-Pierre Simonin and Olivier Bernard for their helpful and constructive comments. The authors warmly thank Andrew Felmy, Christophe Monnin and an anonymous reviewer for their careful and insightful reviews and for their constructive suggestions which allowed improving significantly the quality of the manuscript.

\section{REFERENCES}

Akopov, E. K., 1962, Polytherms of solubility in the system LiCl-KCl- $\mathrm{H}_{2} \mathrm{O}$ : Russian Journal of Inorganic Chemistry, v. 7, p. 385-389.

-, 1963: Russian Journal of Physical Chemistry, v. 36, p. 1918.

Blanc, P., Lassin, A., Piantone, P., Azaroual, M., Jacquemet, N., Fabbri, A., and Gaucher, E. C., 2012, Thermoddem: A geochemical database focused on low temperature water/rock interactions and waste materials: Applied Geochemistry, v. 27, p. 2107-2116.

Blidin, V. P., 1953: DAN SSSR, v. 88, p. 459.

Bradley, D. J., and Pitzer, K. S., 1979, Thermodynamics of electrolytes. 12. Dielectric properties of water and Debye-Hueckel parameters to 350.degree.C and 1 kbar: The Journal of Physical Chemistry, v. 83, p. $1599-1603$.

Brendler, V., and Voigt, W., 1994, Isopiestic measurements at high temperatures. I. Aqueous solutions of $\mathrm{LiCl}, \mathrm{CsCl}$, and $\mathrm{CaCl}_{2}$ at $155^{\circ} \mathrm{C}$ : Journal of Solution Chemistry, v. 23, p. 1061-1072.

Campbell, A. N., and Kartzmark, E. M., 1956, The System $\mathrm{LiCl}-\mathrm{NaCl}-\mathrm{KCl}-\mathrm{H}_{2} \mathrm{O}$ at $25^{\circ} \mathrm{C}$ : Canadian Journal of Chemistry, v. 34, p. 672-678.

Chase, M. W. J., 1998, NIST-JANAF Thermochemical tables, Fourth Edition.: Journal of Physical and Chemical Reference Data, v. Monograph 9, p. 1-1951.

Chernyh, L., Smirnova, T., and Morozova, E., 1987: Russian Journal of Inorganic Chemistry, v. 32, p. 1226-1227.

Christov, C., 1994, Thermodynamic study of $\left(\mathrm{b}_{1} \mathrm{RbCl}+\mathrm{b}_{2} \mathrm{MeCl}_{2}\right)(\mathrm{aq})$, where $\mathrm{b}$ denotes molality and Me denotes $\mathrm{Mn}, \mathrm{Co}, \mathrm{Ni}$, or $\mathrm{Cu}$, at the temperature $298.15 \mathrm{~K}$, on the basis of Pitzer's model: The Journal of Chemical Thermodynamics, v. 26, p. 1071-1080.

-, 1995, Thermodynamic study of $\left(\mathrm{b}_{1} \mathrm{LiBr}+\mathrm{b}_{2} \mathrm{MgBr}_{2}\right)(\mathrm{aq})$, where $\mathrm{b}$ denotes molality, at the temperature 348.15K: The Journal of Chemical Thermodynamics, v. 27, p. 1267-1273. 
-, 1998, Thermodynamic study of the $\mathrm{KCl}-\mathrm{K}_{2} \mathrm{SO}_{4}-\mathrm{K}_{2} \mathrm{Cr}_{2} \mathrm{O}_{7}-\mathrm{H}_{2} \mathrm{O}$ system at the temperature $298.15 \mathrm{~K}$ : Calphad, v. 22, p. 449-457.

-, 2001a, Thermodynamic study of the $\mathrm{K}-\mathrm{Mg}-\mathrm{Al}-\mathrm{Cl}-\mathrm{SO}_{4}-\mathrm{H}_{2} \mathrm{O}$ system at the temperature $298.15 \mathrm{~K}$ : Calphad, v. 25, p. 445-454.

-, 2001b, Thermodynamic study of the $\mathrm{NaCl}-\mathrm{Na}_{2} \mathrm{SO}_{4}-\mathrm{Na}_{2} \mathrm{Cr}_{2} \mathrm{O}_{7}-\mathrm{H}_{2} \mathrm{O}$ system at the temperature 298.15 K: Calphad, v. 25, p. 11-17.

-, 2004, Pitzer ion-interaction parameters for $\mathrm{Fe}(\mathrm{II})$ and $\mathrm{Fe}(\mathrm{III})$ in the quinary $\mathrm{Na}+\mathrm{K}+\mathrm{Mg}+\mathrm{Cl}+\mathrm{SO}_{4}+$ $\mathrm{H}_{2} \mathrm{O}$ \} system at $\mathrm{T}=298.15 \mathrm{~K}$.: Journal of Chemical Thermodynamics, v. 36, p. 223-235.

-, 2005, Thermodynamics of formation of double salts and mixed crystals from aqueous solutions: The Journal of Chemical Thermodynamics, v. 37, p. 1036-1060.

-, 2009, Chemical Equilibrium Model of Solution Behavior and Bishofite $\left(\mathrm{MgCl}_{2}: 6 \mathrm{H}_{2} \mathrm{O}(\mathrm{cr})\right)$ and Hydrogen-Carnallite $\left(\mathrm{HCl}: \mathrm{MgCl}_{2}: 7 \mathrm{H}_{2} \mathrm{O}(\mathrm{cr})\right.$ ) Solubility in the $\mathrm{MgCl}_{2}+\mathrm{H}_{2} \mathrm{O}$ and $\mathrm{HCl}-\mathrm{MgCl}_{2}+$ $\mathrm{H}_{2} \mathrm{O}$ Systems to High Acid Concentration at $(0$ to 100$){ }^{\circ} \mathrm{C}$ : Journal of Chemical \& Engineering Data, v. 54, p. 2599-2608.

-, 2012, Temperature variable chemical model of bromide-sulfate solution interaction parameters and solid-liquid equilibria in the $\mathrm{Na}-\mathrm{K}-\mathrm{Ca}-\mathrm{Br}-\mathrm{SO}_{4}-\mathrm{H}_{2} \mathrm{O}$ system: Calphad, v. 36, p. 71-81.

Christov, C., Balarew, C., Petrenko, S., and Valyashko, V., 1994, Investigation of the aqueous lithium and magnesium halide systems: Journal of Solution Chemistry, v. 23, p. 595-604.

Christov, C., Dickson, A., and Møller, N., 2007, Thermodynamic Modeling of Aqueous Aluminum Chemistry and Solid-Liquid Equilibria to High Solution Concentration and Temperature. I. The Acidic H-Al-Na-K-Cl- $\mathrm{H}_{2} \mathrm{O}$ System from 0 to $100^{\circ} \mathrm{C}$ : Journal of Solution Chemistry, v. 36, p. 1495-1523.

Christov, C., and Møller, N., 2004a, A chemical equilibrium model of solution behavior and solubility in the $\mathrm{H}-\mathrm{Na}-\mathrm{K}-\mathrm{Ca}-\mathrm{OH}-\mathrm{Cl}-\mathrm{HSO}_{4}-\mathrm{SO}_{4}-\mathrm{H}_{2} \mathrm{O}$ system to high concentration and temperature: Geochimica et Cosmochimica Acta, v. 68, p. 3717-3739.

-, 2004b, Chemical equilibrium model of solution behavior and solubility in the $\mathrm{H}-\mathrm{Na}-\mathrm{K}-\mathrm{OH}-\mathrm{Cl}-\mathrm{HSO}_{4}$ $\mathrm{SO}_{4}-\mathrm{H}_{2} \mathrm{O}$ system to high concentration and temperature: Geochimica et Cosmochimica Acta, v. 68, p. 1309-1331.

Christov, C., Velikova, S., and Ivanova, K., 2000, Study of $\left(\mathrm{m}_{1} \mathrm{LiX}+\mathrm{m}_{2} \mathrm{CaX}_{2}\right)(\mathrm{aq})$ where mi denotes molality and $\mathrm{X}$ denotes $\mathrm{Cl}$, or $\mathrm{Br}$ at the temperature $298.15 \mathrm{~K}$ : The Journal of Chemical Thermodynamics, v. 32, p. 1505-1512.

Christov, C., Velikova, S., Ivanova, K., and Tanev, S., 1999, Thermodynamic Study of $\mathrm{Na}_{2} \mathrm{Cr}_{2} \mathrm{O}_{7}(\mathrm{aq})$ at $25^{\circ} \mathrm{C}$ : Collect. Czech. Chem. Commun., v. 64, p. 595-599.

Chu, K.-J., and Zai, W.-T., 1965: Acta Chimica Sinica, v. 31, p. 192.

CODATA, 1978, CODATA recommended key values for thermodynamics, 1977 Report of the CODATA Task Group on key values for thermodynamics, 1977: The Journal of Chemical Thermodynamics, v. 10, p. 903-906.

Cohen-Adad, R., 1991, Lithium Chloride, in Cohen-Adad, R., and Lorimer, J. W., editors, Alkali Metal and Ammonium Chlorides in Water and Heavy Water (Binary Systems): Amsterdam, Pergamon, p. 1-63.

Doherty, J., 2004, PEST. Model-independent parameter estimation. User manual: $5^{\text {th }}$ Edition, Watermark Numerical Computing, http://www.pesthomepage.org/

Dubois, M., Monnin, C., Castelain, T., Coquinot, Y., Gouy, S., Gauthier, A., and Goffé, B., 2010, Investigation of the $\mathrm{H}_{2} \mathrm{O}-\mathrm{NaCl}-\mathrm{LiCl}$ System: A Synthetic Fluid Inclusion Study and Thermodynamic Modeling from $-50^{\circ}$ to $+100^{\circ} \mathrm{C}$ and up to $12 \mathrm{~mol} / \mathrm{kg}$ : Economic Geology, v. 105, p. 329-338.

Ebensperger, A., Maxwell, P., and Moscoso, C., 2005, The lithium industry: Its recent evolution and future prospects: Resources Policy, v. 30, p. 218-231.

Egorov, A. V., Komolkin, A. V., Chizhik, V. I., Yushmanov, P. V., Lyubartsev, A. P., and Laaksonen, A., 2003, Temperature and concentration effects on Li+-ion hydration. A molecular dynamics simulation study: Journal of Physical Chemistry B, v. 107, p. 3234-3242. 
El Guendouzi, M., Benbiyi, A., Dinane, A., and Azougen, R., 2003, The thermodynamic study of the system $\mathrm{LiCl}-\mathrm{KCl}-\mathrm{H}_{2} \mathrm{O}$ at the temperature $298.15 \mathrm{~K}$ : Calphad, v. 27, p. 213-219.

-, 2004, Thermodynamic properties of multicomponent $\mathrm{NaCl}-\mathrm{LiCl}-\mathrm{H}_{2} \mathrm{O}$ aqueous solutions at temperature 298.15 K: Calphad, v. 28, p. 97-103.

Engel, R., 1888: Annales de Chimie et de Physique, v. 13, p. 385.

Evteeva, O. G., 1965: Izv. Sib. Otd. Akad. Nauk. SSSR, Ser. Khim. Nauk., v. 7, p. 144.

Farelo, F., Fernandes, C., and Avelino, A., 2005, Solubilities for Six Ternary Systems: $\mathrm{NaCl}+\mathrm{NH}_{4} \mathrm{Cl}+$ $\mathrm{H}_{2} \mathrm{O}, \mathrm{KCl}+\mathrm{NH}_{4} \mathrm{Cl}+\mathrm{H}_{2} \mathrm{O}, \mathrm{NaCl}+\mathrm{LiCl}+\mathrm{H}_{2} \mathrm{O}, \mathrm{KCl}+\mathrm{LiCl}+\mathrm{H}_{2} \mathrm{O}, \mathrm{NaCl}+\mathrm{AlCl}_{3}+\mathrm{H}_{2} \mathrm{O}$, and $\mathrm{KCl}+\mathrm{AlCl}_{3}+\mathrm{H}_{2} \mathrm{O}$ at $\mathrm{T}=(298$ to 333) $\mathrm{K}$ : Journal of Chemical \& Engineering Data, v. 50, p. $1470-1477$.

Felmy, A. R., Cho, H., Rustad, J. R., and Mason, M. J., 2001, An aqueous thermodynamic model for polymerized silica species to high ionic strength: Journal of Solution Chemistry, v. 30, p. 509525.

Felmy, A. R., and Weare, J. H., 1986, The prediction of borate mineral equilibria in natural waters: Application to Searles Lake, California: Geochimica et Cosmochimica Acta, v. 50, p. 2771-2783.

Garrett, D. E., 2004, Handbook of lithium and natural calcium chloride. Their deposits, processing, uses and properties, Elsevier Academic Press, 476 p.

Gibbard, H. F., and Scatchard, G., 1973, Liquid-vapor equilibrium of aqueous lithium chloride, from 25 to 100.deg. and from 1.0 to 18.5 molal, and related properties: Journal of Chemical \& Engineering Data, v. 18, p. 293-298.

Greenberg, J. P., and Møller, N., 1989, The prediction of mineral solubilities in natural waters: A chemical equilibrium model for the $\mathrm{Na}-\mathrm{K}-\mathrm{Ca}-\mathrm{Cl}-\mathrm{SO}_{4}-\mathrm{H}_{2} \mathrm{O}$ system to high concentration from 0 to $250^{\circ} \mathrm{C}$ : Geochimica et Cosmochimica Acta, v. 53, p. 2503-2518.

Grosjean, C., Miranda, P. H., Perrin, M., and Poggi, P., 2012, Assessment of world lithium resources and consequences of their geographic distribution on the expected development of the electric vehicle industry: Renewable and Sustainable Energy Reviews, v. 16, p. 1735-1744.

Gruber, P. W., Medina, P. A., Keoleian, G. A., Kesler, S. E., Everson, M. P., and Wallington, T. J., 2011, Global Lithium Availability: Journal of Industrial Ecology, v. 15, p. 760-775.

Gruszkiewicz, M. S., and Simonson, J. M., 2005, Vapor pressures and isopiestic molalities of concentrated $\mathrm{CaCl}_{2}(\mathrm{aq}), \mathrm{CaBr}_{2}(\mathrm{aq})$, and $\mathrm{NaCl}(\mathrm{aq})$ to $\mathrm{T}=523 \mathrm{~K}$ : The Journal of Chemical Thermodynamics, v. 37, p. 906-930.

Gueddari, M., Monnin, C., Perret, D., Fritz, B., and Tardy, Y., 1983, Geochemistry of Brines of the Chott-El-Jerid in Southern Tunisia - Application of Pitzers Equations: Chemical Geology, v. 39, p. $165-178$.

Hamer, W. J., and Wu, Y.-C., 1972, Osmotic Coefficients and Mean Activity Coefficients of Uniunivalent Electrolytes in Water at $25^{\circ} \mathrm{C}$ : Journal of Physical and Chemical Reference Data, v. 1, p. 1047-1099.

Harsányi, I., Bopp, P. A., Vrhovšek, A., and Pusztai, L., 2011, On the hydration structure of LiCl aqueous solutions: A Reverse Monte Carlo based combination of diffraction data and Molecular Dynamics simulations: Journal of Molecular Liquids, v. 158, p. 61-67.

Harvie, C. E., Møller, N., and Weare, J. H., 1984, The prediction of mineral solubilities in natural waters: The Na-K-Mg-Ca-H-Cl-SO $\mathrm{S}_{4}-\mathrm{OH}-\mathrm{HCO}_{3}-\mathrm{CO}_{3}-\mathrm{CO}_{2}-\mathrm{H}_{2} \mathrm{O}$ system to high ionic strengths at $25^{\circ} \mathrm{C}$ : Geochimica et Cosmochimica Acta, v. 48, p. 723-751.

Harvie, C. E., and Weare, J. H., 1980, The prediction of mineral solubilities in natural waters: the Na-K$\mathrm{Mg}-\mathrm{Ca}-\mathrm{Cl}-\mathrm{SO}_{4}-\mathrm{H}_{2} \mathrm{O}$ system from zero to high concentration at $25^{\circ} \mathrm{C}$ : Geochimica et Cosmochimica Acta, v. 44, p. 981-997.

Helgeson, H. C., Delany, J. M., Nesbitt, H. W., and Bird, D. K., 1978, Summary and critique of the thermodynamic properties of rock-forming minerals.: American Journal of Science, v. 278-A, p. $229 \mathrm{p}$.

Hellams, K., Paterson, C., Prentice, B., and Taylor, M., 1965, Osmotic Properties of Some Aqueous Solutions at $45{ }^{\circ} \mathrm{C}$ : Journal of Chemical and Engineering Data, v. 10, p. 323-325. 
Herz, W., 1912: Zeitschrift für anorganische und allgemeine Chemie, v. 73, p. 274.

Holmes, H. F., Baes Jr, C. F., and Mesmer, R. E., 1978, Isopiestic studies of aqueous solutions at elevated temperatures I. $\mathrm{KCl}, \mathrm{CaCl}_{2}$, and $\mathrm{MgCl}_{2}$ : The Journal of Chemical Thermodynamics, v. 10, p. 983996.

Holmes, H. F., and Mesmer, R. E., 1981, Isopiestic studies of aqueous solutions at elevated temperatures VI. $\mathrm{LiCl}$ and $\mathrm{CsCl}$ : The Journal of Chemical Thermodynamics, v. 13, p. 1035-1046.

-, 1983, Thermodynamic Properties of Aqueous Solutions of the Alkali Metal Chlorides to $250^{\circ} \mathrm{C}$ : Journal of Physical Chemistry, v. 87, p. 1242-1255.

-, 1998a, Isopiestic molalities for aqueous solutions of the alkali metal hydroxides at elevated temperatures: The Journal of Chemical Thermodynamics, v. 30, p. 311-326.

-, 1998b, An isopiestic study of aqueous solutions of the alkali metal bromides at elevated temperatures: The Journal of Chemical Thermodynamics, v. 30, p. 723-741.

Itkina, L., Chaplighina, N., and Portnova, S., 1967: Russian Journal of Inorganic Chemistry, v. 12, p. 547.

Itkina, L., Portnova, S., and Chaplighina, N., 1968: Russian Journal of Inorganic Chemistry, v. 13, p. 1415.

Kangro, W., and Groeneveld, A., 1962, Konzentrierte wäßrige Lösungen, I: Zeitschrift für Physikalische Chemie Neue Folge, v. 32, p. 110-26.

Khy, K.-Y., 1960: Russian Journal of Physical Chemistry, v. 5, p. 190-192.

Kim, H. T., and Frederick, W. J., 1988a, Evaluation of Pitzer ion interaction parameters of aqueous electrolytes at $25^{\circ} \mathrm{C}$. 1 . Single salt parameters: Journal of Chemical \& Engineering Data, v. 33, p. 177-184.

-, 1988b, Evaluation of Pitzer ion interaction parameters of aqueous mixed electrolyte solutions at $25^{\circ} \mathrm{C}$. 2. Ternary mixing parameters: Journal of Chemical \& Engineering Data, v. 33, p. 278-283.

Kindyakov, P. S., Kychtymova, E. A., and Rogova, S. T., 1958: Trudy MITKhT im. Lomonossova, v. 7 , p. $25,28,30$.

Kirgintsev, A. N., Trushnikova, L. N., and Lavrent'eva, V. G., 1972, Solubility of inorganic substances in water: St. Petersburg, Khimia, UDK, 541 p.

Kushnir, D., and Sandén, B. A., 2012, The time dimension and lithium resource constraints for electric vehicles: Resources Policy, v. 37, p. 93-103.

Lassin, A., Kervevan, C., Andre, L., and Azaroual, M., 2009, Pitzer parametrization constrained by density: application to natural and industrial systems, 19th Annual VM Goldschmidt Conference: Davos, Switzerland, Geochimica et Cosmochimica Acta, Pergamon-Elsevier Science LTD, p. A724-A724.

Li, Y., Song, P., Xia, S., and Gao, S., 2000, Prediction of the component solubility in the ternary systems $\mathrm{HCl}-\mathrm{LiCl}-\mathrm{H}_{2} \mathrm{O}, \mathrm{HCl}-\mathrm{MgCl}_{2}-\mathrm{H}_{2} \mathrm{O}$ and $\mathrm{LiCl}-\mathrm{MgCl}_{2}-\mathrm{H}_{2} \mathrm{O}$ at $0{ }^{\circ} \mathrm{C}$ and $20{ }^{\circ} \mathrm{C}$ using the ioninteraction model: Calphad, v. 24, p. 295-308.

Linke, W., 1965, Solubilities of inorganic and metal-organic compounds, 4th Edition, v. 1 and 2: Washington, American Chemical Society.

Marion, G. M., Catling, D. C., and Kargel, J. S., 2003, Modeling aqueous ferrous iron chemistry at low temperatures with application to Mars.: Geochimica and Cosmochimica Acta, v. 67, p. 42514266.

Mikulin, G., 1968, Voprosy Fizicheskoi Khimii Electrolytov: St. Petersburg, Izd. Khimiya.

Møller, N., 1988, The prediction of mineral solubilities in natural waters: A chemical equilibrium model for the Na-Ca-Cl- $\mathrm{SO}_{4}-\mathrm{H}_{2} \mathrm{O}$ system, to high temperature and concentration: Geochimica et Cosmochimica Acta, v. 52, p. 821-837.

Møller, N., Christov, C., and Weare, J. H., 2005, Models of subsurface rock water chemical processes affecting fluid flow, $30^{\text {th }}$ Workshop on Geothermal Reservoir Engineering: Stanford University, Stanford, California, USA.

-, 2006, Thermodynamic models of aluminium silicate mineral solubility for application to enhanced geothermal systems, $31^{\text {st }}$ Workshop on Geothermal Reservoir Engineering: Stanford University, Stanford, California, USA. 
-, 2007, Thermodynamic model for predicting interactions of geothermal brines with hydrothermal aluminum silicate minerals, $32^{\text {nd }}$ Workshop on Geothermal Reservoir Engineering: Stanford University, Stanford, California, USA.

Monnin, C., and Dubois, M., 2005, Thermodynamics of the $\mathrm{LiOH}+\mathrm{H}_{2} \mathrm{O}$ System: Journal of Chemical \& Engineering Data, v. 50, p. 1109-1113.

Monnin, C., Dubois, M., Papaiconomou, N., and Simonin, J.-P., 2002, Thermodynamics of the LiCl + $\mathrm{H}_{2} \mathrm{O}$ System: Journal of Chemical \& Engineering Data, v. 47, p. 1331-1336.

Moore, J., Humphries, W., and Paterson, C., 1972, Isopiestic Studies of Some Aqueous Electrolyte Solutions at $80{ }^{\circ} \mathrm{C}$ : Journal of Chemical and Engineering Data, v. 17, p. 180-182.

Nasirzadeh, K., Neueder, R., and Kunz, W., 2005, Vapor Pressures and Osmotic Coefficients of Aqueous LiOH Solutions at Temperatures Ranging from 298.15 to $363.15 \mathrm{~K}$ : Industrial \& Engineering Chemistry Research, v. 44, p. 3807-3814.

Ojkova, T., Christov, C., and Mihov, D., 1998, Investigation of the Aqueous Lithium and Nickel Selenate System: Zeitschrift fur Physikalische Chemie, v. 203, p. 87-93.

Pabalan, R. T., and Pitzer, K. S., 1987, Thermodynamics of concentrated electrolyte mixtures and the prediction of mineral solubilities to high temperatures for mixtures in the system $\mathrm{Na}-\mathrm{K}-\mathrm{Mg}-\mathrm{Cl}$ $\mathrm{SO}_{4}-\mathrm{OH}-\mathrm{H}_{2} \mathrm{O}$ : Geochimica et Cosmochimica Acta, v. 51, p. 2429-2443.

Palmer, D. A., Rard, J. A., and Clegg, S. L., 2002, Isopiestic determination of the osmotic and activity coefficients of $\mathrm{Rb}_{2} \mathrm{SO}_{4}(\mathrm{aq})$ and $\mathrm{Cs}_{2} \mathrm{SO}_{4}(\mathrm{aq})$ at $\mathrm{T}=(298.15$ and 323.15) $\mathrm{K}$, and representation with an extended ion-interaction (Pitzer) model: The Journal of Chemical Thermodynamics, v. 34, p. 63-102.

Parkhurst, D. L., and Appelo, C. A. J., 1999, User's guide to PHREEQC (version 2) - A computer program for speciation, batch-reaction, one-dimensional transport, and inverse geochemical calculation, U.S. Geological Survey, p. 312.

Patil, K. R., Tripathi, A. D., Pathak, G., and Katti, S. S., 1990, Thermodynamic properties of aqueous electrolyte solutions. 1. Vapor pressure of aqueous solutions of lithium chloride, lithium bromide, and lithium iodide: Journal of Chemical \& Engineering Data, v. 35, p. 166-168.

Pauwels, H., Brach, M., and Fouillac, C., 1995, Study of $\mathrm{Li}^{+}$adsorption onto polymeric aluminium (III) hydroxide for application in the treatment of geothermal waters: Colloids and Surfaces A: Physicochemical and Engineering Aspects, v. 100, p. 73-82.

Pauwels, H., Fouillac, C., and Fouillac, A.-M., 1993, Chemistry and Isotopes of Deep Geothermal Saline Fluids in the Upper Rhine Graben - Origin of Compounds and Water-Rock Interactions: Geochimica et Cosmochimica Acta, v. 57, p. 2737-2749.

Petit, L., Vuilleumier, R., Maldivi, P., and Adamo, C., 2008, Ab Initio Molecular Dynamics Study of a Highly Concentrated LiCl Aqueous Solution: Journal of Chemical Theory and Computation, v. 4, p. 1040-1048.

Petrenko, S. V., and Pitzer, K. S., 1997, Thermodynamics of aqueous $\mathrm{NaOH}$ over the complete composition range and to $523 \mathrm{~K}$ and $400 \mathrm{MPa}$. J. Phys. Chem. B, v. 101, p. 3589-3595.

Pitzer, K. S., 1973, Thermodynamics of electrolytes. I. Theoretical basis and general equations: Journal of Physical Chemistry, v. 77, p. 268-277.

Pitzer, K. S., 1991, Activity coefficients in electrolyte solutions. 2nd edition, CRC Press: Boca Raton, Florida, USA, p. 542.

Pitzer, K. S., and Kim, J. J., 1974, Thermodynamics of electrolytes. IV. Activity and osmotic coefficients for mixed electrolytes: Journal of the American Chemical Society, v. 96, p. 5701-5707.

Pitzer, K. S., and Mayorga, G., 1973, Thermodynamics of electrolytes. II. Activity and osmotic coefficients for strong electrolytes with one or both ions univalent: The Journal of Physical Chemistry, v. 77, p. 2300-2308.

-, 1974, Thermodynamics of electrolytes. III. Activity and osmotic coefficients for 2-2 electrolytes: Journal of Solution Chemistry, v. 3, p. 539-546.

Pitzer, K. S., Peiper, J. C., and Busey, R. H., 1984, Thermodynamic Properties of Aqueous Sodium Chloride Solutions: Journal of Physical and Chemical Reference Data, v. 13, p. 1-102. 
Pitzer, K. S., and Silvester, L. F., 1976, Thermodynamics of electrolytes. VI. Weak electrolytes including $\mathrm{H}_{3} \mathrm{PO}_{4}$ : Journal of Solution Chemistry, v. 5 .

Pitzer, K., Wang, P., Rard, J., and Clegg, S., 1999, Thermodynamics ofelectrolytes. 13. Ionic strength dependence of higher-order terms; equations for $\mathrm{CaCl}_{2}$ and $\mathrm{MgCl}_{2}$ : Journal of Solution Chemistry, v. 28, p. 265-282.

Plummer, L. N., Parkhurst, D. L., Fleming, G. W., and Dunkle, S. A., 1988, A computer program incorporating Pitzer's equations for calculation of geochemical reactions in brines, in Survey, U. S. G., editor, Water-Resources Investigations Report: Reston, Virginia, p. 193.

Plyushchev, V. E., Kuznetsova, G. P., and Stepina, S. B., 1959: Zhurnal Neorganicheskoi Khimii, v. 4, p. 1450.

Rard, J., and Clegg, S., 1997, Critical evaluation of the thermodynamicproperties of aqueous calcium chloride. 1. Osmotic and activity coefficients of $0-10.77 \mathrm{~mol} . \mathrm{kg}^{-1}$ aqueous calcium chloride solutions at $298.15 \mathrm{~K}$ and correlation with extended Pitzer ioninteraction models: Journal of Chemical \& Engineering Data, v. 42, p. 819-849.

Reardon, E. J., 1988, Ion interaction parameters for aluminum sulfate and application to the prediction of metal sulfate solubility in binary salt systems: The Journal of Physical Chemistry, v. 92, p. 64266431.

Risacher, F., and Fritz, B., 2009, Origin of Salts and Brine Evolution of Bolivian and Chilean Salars: Aquatic Geochemistry, v. 15, p. 123-157.

Robinson, R. A., and Stokes, R. H., 1949, Tables of osmotic and activity coefficients of electrolytes in aqueous solution at $25^{\circ}$ C: Transactions of the Faraday Society, v. 45, p. 612-624.

Rollet, A., and Cohen-Adad, R., 1964, Les systèmes "eau-hydroxide alcalin": Revue de Chimie Minérale, v. 1, p. 451.

Rudolph, W., Brooker, M. H., and Pye, C. C., 1995, Hydration of Lithium Ion in Aqueous Solution: Journal of Physical Chemistry, v. 99, p. 3793-3797.

Rumyantsev, A. V., Hagemann, S., and Moog, H. C., 2004, Isopiestic Investigation of the Systems $\mathrm{Fe}_{2}\left(\mathrm{SO}_{4}\right)_{3}-\mathrm{H}_{2} \mathrm{SO}_{4}-\mathrm{H}_{2} \mathrm{O}, \mathrm{FeCl}_{3}-\mathrm{H}_{2} \mathrm{O}$, and $\mathrm{Fe}(\mathrm{III})-(\mathrm{Na}, \mathrm{K}, \mathrm{Mg}, \mathrm{Ca}) \mathrm{Cl}_{\mathrm{n}}-\mathrm{H}_{2} \mathrm{O}$ at $298.15 \mathrm{~K}$ : Zeitschrift fur Physikalische Chemie, v. 218, p. 1089-1127.

Shock, E. L., and Helgeson, H. C., 1988, Calculation of the thermodynamic and transport properties of aqueous species at high pressures and temperatures: Correlation algorithms for ionic species and equation of state predictions to $5 \mathrm{~kb}$ and $1000^{\circ} \mathrm{C}$ : Geochimica and Cosmochimica Acta, v. 52, p. 2009-2036.

Smits, A., Elgersma, J., and Hardenberg, M. M. E., 1924, A critical mixing point in the solid phase of the system NaCl-LiCl: Recueil des Travaux Chimiques des Pays-Bas, v. 43, p. 671-676.

Song, P., and Yao, Y., 2001, Thermodynamics and Phase Diagram of the Salt Lake Brine System at $25^{\circ} \mathrm{C}$ I. $\mathrm{Li}^{+}, \mathrm{K}^{+}, \mathrm{Mg}^{2+} / \mathrm{Cl}^{-}, \mathrm{SO}_{4}{ }^{2-},-\mathrm{H}_{2} \mathrm{O}$ System: Calphad, v. 25 , p. 329-341.

-, 2003, Thermodynamics and phase diagram of the salt lake brine system at $298.15 \mathrm{~K}$ : V. Model for the system $\mathrm{Li}^{+}, \mathrm{Na}^{+}, \mathrm{K}^{+}, \mathrm{Mg}^{2+} / \mathrm{Cl}^{-}, \mathrm{SO}_{4}{ }^{2-}-\mathrm{H}_{2} \mathrm{O}$ and its applications: Calphad, v. 27, p. 343-352.

Sterner, S. M., Felmy, A. R., Oakes, C. S., and Pitzer, K. S., 1998, Correlation of thermodynamic data for aqueous electrolyte solutions to very high ionic strength using INSIGHT: Vapor saturated water activity in the system $\mathrm{CaCl}_{2}-\mathrm{H}_{2} \mathrm{O}$ to $250{ }^{\circ} \mathrm{C}$ and solid saturation, Symposium on thermophysical properties: Boulder, CO (United States), International Journal of Thermophysics, p. 761-770.

Sverjensky, D. A., Shock, E. L., and Helgeson, H. C., 1997, Prediction of the thermodynamic properties of aqueous metal complexes to $1000^{\circ} \mathrm{C}$ and $5 \mathrm{~kb}$ : Geochimica and Cosmochimica Acta, v. 61, p. $1359-1412$.

Tanaka, K., Ogita, N., Tamura, Y., Okada, I., Ohtaki, H., Pálinkás, G., Spohr, E., and Heinzinger, K., 1987, A Molecular Dynamics Study of the Structure of an LiCl. $3 \mathrm{H}_{2} \mathrm{O}$ Solution: Z. Naturforsch., v. 42a, p. 29-34.

Valyashko, V. M., Urusova, M. A., Voigt, W., and Emons, H. H., 1988: Zh. Neorg. Khim., v. 33, p. 228. 
Warren, J. K., 2010, Evaporites through time: Tectonic, climatic and eustatic controls in marine and nonmarine deposits: Earth-Science Reviews, v. 98, p. 217-268.

Yanatieva, O. K., 1947: Zh. Obshch. Khim., v. 17, p. 1039-43.

Yanko, A. P., and Goldanel, A. Y., 1964: Izv. Phyz.-Khim, v. 6, p. 146.

Zatloukal, J., Jäger, L., Machala, J., and Jerman, Z., 1959: Chem. Průmysl, v. 9, p. 305.

Zdanovskii, A. B., Solov'eva, E. F., Lyakhovskaya, E. I., Shestakov, N. E., Shleimovich, R. E., and Abutkova, L. M., 1973, Experimental solubility data on salt - water systems. Vol. 1, Three component systems, v. 1: Leningrad, "Chemistry" Publishing, 1070 p.

-, 1975, Experimental solubility data on salt - water systems. Vol. 2, four component and more complex systems, v. 2: Leningrad, "Chemistry" Publishing, 1064 p.

Zeng, D., Liu, H., and Chen, Q., 2007, Simulation and prediction of solubility phase diagram for the separation of $\mathrm{MgCl}_{2}$ from $\mathrm{LiCl}$ brine using $\mathrm{HCl}$ as a salting-out agent: Hydrometallurgy, v. 89, p. 21-31.

Zhang, A.-Y., Yao, Y., Li, L.-J., and Song, P.-S., 2005, Isopiestic determination of the osmotic coefficients and Pitzer model representation for $\mathrm{Li}_{2} \mathrm{~B}_{4} \mathrm{O}_{7}(\mathrm{aq})$ at $\mathrm{T}=298.15 \mathrm{~K}$ : The Journal of Chemical Thermodynamics, v. 37, p. 101-109.

Zhang, X.-Y., Févotte, G., Qian, G., Zhou, X.-G., and Yuan, W.-K., 2011, Solubility prediction of weak electrolyte mixtures, ISIC $18,18^{\text {th }}$ International Symposium on Industrial Crystallization: Zurich, Switzerland.

Zhou, J., Chen, Q. Y., Li, J., Yin, Z. L., Zhou, X., and Zhang, P. M., 2003, Isopiestic measurement of the osmotic and activity coefficients for the $\mathrm{NaOH}-\mathrm{NaAl}(\mathrm{OH})_{4}-\mathrm{H}_{2} \mathrm{O}$ system at $313.2 \mathrm{~K}$ : Geochimica et Cosmochimica Acta, v. 67, p. 3459-3472. 


\section{Figure captions}

Figure 1 - Experimental aqueous (osmotic coefficient, $\varphi$ ) and solubility data used for the $\mathrm{LiCl}^{-\mathrm{H}_{2} \mathrm{O}}$ binary system, as a function of temperature. Crosses represent aqueous data: from Gibbard and Scatchard (1973) for 273.15 to $373.15 \mathrm{~K}$; from Robinson and Stokes (1949) and from Mikulin (1968) at $298.15 \mathrm{~K}$; from Hellams and others (1965) at $318.15 \mathrm{~K}$; from Moore and others (1972) at $353.15 \mathrm{~K}$; from Holmes and Mesmer (1981) for 383.15 to $473.15 \mathrm{~K}$; from Brendler and Voigt (1994) at $428.15 \mathrm{~K}$ (not included in parameterization); from Holmes and Mesmer (1983) for 498.15 to $523.15 \mathrm{~K}$. Black diamonds represent solubility data for $\mathrm{LiCl} . n \mathrm{H}_{2} \mathrm{O}(\mathrm{cr})$ solids $(n=0,1$ or 2 ) from compilations of Linke (1965), Zdanovskii and others (1973), and Garrett (2004), and from Farelo and others (2005). Triangles represent phase transition $\left(292.55 \mathrm{~K}\right.$ : $\mathrm{LiCl} .2 \mathrm{H}_{2} \mathrm{O}$ (cr) to $\mathrm{LiCl}_{2} \mathrm{H}_{2} \mathrm{O}(\mathrm{cr})$ and $369.15 \mathrm{~K}$ : $\mathrm{LiCl}_{2} \mathrm{H}_{2} \mathrm{O}(\mathrm{cr})$ to $\mathrm{LiCl}(\mathrm{cr})$ ) points of Kirgintsev and others (1972). Grey diamonds represent high temperature (473.15 K and $523.15 \mathrm{~K}) \mathrm{LiCl}(\mathrm{cr})$ solubility calculated using solubility-temperature relationship given by Monnin and others (2002) (their table 1) and based on the compilation of Cohen-Adad (1991). Circles represent $\mathrm{LiCl}_{2} \mathrm{H}_{2} \mathrm{O}$ (cr) solubility at $273.15 \mathrm{~K}$ (Garrett, 2004) and 283.15 K (Zdanovskii and others, 1973) (not included in parameterization).

Figure 2 - Calculated (lines) and experimental (diamonds) osmotic coefficients, $\varphi$, for the $\mathrm{LiCl}^{-\mathrm{H}_{2} \mathrm{O}}$ binary system as a function of total molality of $\mathrm{LiCl}$ : A) at $273.15 \mathrm{~K}, \mathrm{~B}$ ) at $298.15 \mathrm{~K}, \mathrm{C}$ ) at $335.65 \mathrm{~K}$, D) at $373.15 \mathrm{~K}, \mathrm{E}$ ) at $443.15 \mathrm{~K}, \mathrm{~F}$ ) at $523.15 \mathrm{~K}$, and $\mathrm{G}$ ) at $428.15 \mathrm{~K}$ (not used in parameterization). Experimental data - see figure 1 caption. Dashed lines are values calculated with model 1 (without the $\mathrm{LiCl}$,aq neutral species, but with $\alpha_{2}$ and $\beta^{(2)}$ parameters) and solid lines are values calculated with model 2.

Figure 3 - Experimental (symbols) and calculated (lines) solubility of $\mathrm{LiCl} . n \mathrm{H}_{2} \mathrm{O}(\mathrm{cr})(n=0,1$ or 2$)$ solids as a function of temperature in the $\mathrm{LiCl}-\mathrm{H}_{2} \mathrm{O}$ binary system. Experimental data - see figure 1 caption. Dashed lines are values calculated with model 1 (without the $\mathrm{LiCl}^{0}$ (aq) neutral species, but with $\alpha_{2}$ and $\beta^{(2)}$ parameters) and solid lines are values calculated with model 2.

Figure 4 - Estimated pure electrolyte parameters for the $\mathrm{LiCl}-\mathrm{H}_{2} \mathrm{O}$ binary system from 273.15 to 523.15 $\mathrm{K}$ : A) model 1 (no $\mathrm{LiCl}^{0}(\mathrm{aq})$ ): $\beta^{(0)}\left(\mathrm{Li}^{+}, \mathrm{Cl}^{-}\right)$(solid line), $\beta^{(1)}\left(\mathrm{Li}^{+}, \mathrm{Cl}^{-}\right)$(long-dashed line), $\beta^{(2)}\left(\mathrm{Li}^{+}, \mathrm{Cl}^{-}\right)$(dotdashed line), and $\mathrm{C}^{\varphi}\left(\mathrm{Li}^{+}, \mathrm{Cl}^{-}\right)$(short-dashed line), B) model 2: $\beta^{(0)}\left(\mathrm{Li}^{+}, \mathrm{Cl}^{-}\right)$(solid line), $\beta^{(1)}\left(\mathrm{Li}^{+}, \mathrm{Cl}^{-}\right)$(longdashed line), and $\mathrm{C}^{\varphi}\left(\mathrm{Li}^{+}, \mathrm{Cl}^{-}\right)$(short-dashed line)

Figure 5 - Comparison of the thermodynamic solubility product (as $\log \mathrm{K}_{\mathrm{sp}}^{\mathrm{o}}$ ) of lithium chloride solids determined in this study (lines) with the recommended values (symbols) from 0 to $250^{\circ} \mathrm{C}$ : A) model 1 (without the $\mathrm{LiCl}^{0}(\mathrm{aq})$ neutral species, but with $\alpha_{2}$ and $\beta^{(2)}$ parameters), B) model 2. Dot-dashed line: LiCl. $2 \mathrm{H}_{2} \mathrm{O}(\mathrm{cr})$; long-dashed line: $\mathrm{LiCl} . \mathrm{H}_{2} \mathrm{O}(\mathrm{cr})$; short-dashed line: $\mathrm{LiCl}(\mathrm{cr})$; solid line: $\mathrm{LiCl}^{\mathrm{O}}(\mathrm{aq})$. White diamonds, triangles and circles: $\log \mathrm{K}_{\text {sp }}^{\mathrm{o}}$ recommended by Monnin and others (2002) for $\mathrm{LiCl} .2 \mathrm{H}_{2} \mathrm{O}(\mathrm{cr}$ ), LiCl. $\mathrm{H}_{2} \mathrm{O}$ (cr) and $\mathrm{LiCl}(\mathrm{cr})$, respectively. Black triangle: $\log \mathrm{K}_{\text {sp }}^{\mathrm{o}}\left(\mathrm{LiCl}_{2} \mathrm{H}_{2} \mathrm{O}(\mathrm{cr})\right.$ ) from Christov (2005). Black circles: $\log \mathrm{K}_{\text {sp }}^{\circ}$ of $\mathrm{LiCl}(\mathrm{cr})$ calculated using the $\mathrm{LiCl}(\mathrm{cr})$ calorimetric data $\left(\Delta \mathrm{H}_{\mathrm{f}}^{\circ}, \mathrm{S}^{\circ}\right.$ and $\left.\mathrm{C}_{\mathrm{p}}\right)$ from Chase (1998) and the standard thermodynamic properties $\left(\Delta \mathrm{G}_{\mathrm{f}}^{\circ}, \mathrm{S}^{\circ}\right.$, HKF parameters) of $\mathrm{Li}^{+}$and $\mathrm{Cl}^{-}$ aqueous species from Shock and Helgeson (1988). For model 2, the equilibrium dissociation constant $\mathrm{pK}\left(\mathrm{LiCl}^{0}(\mathrm{aq})\right)$ of the neutral aqueous specie $\left(\mathrm{LiCl}^{0}(\mathrm{aq})\right)$, determined in this study, is also plotted (dotdashed line).

Figure 6 - Calculated mean $\mathrm{LiCl}$ activity coefficients in $\mathrm{LiCl}-\mathrm{H}_{2} \mathrm{O}$ solutions vs. molality, from 273.15 to $523.15 \mathrm{~K}$ according to model 2 . The grey solid line represents the calculated solubility of $\mathrm{LiCl} . n \mathrm{H}_{2} \mathrm{O}$ (cr) $(n=0,1$ or 2 ) solids (see also figure 3 ). 
Figure 7 - Model 2 predictions for the distribution of ionic $\left(\mathrm{Li}^{+}, \mathrm{Cl}^{-}\right)$and neutral $\left(\mathrm{LiCl}^{0}(\mathrm{aq})\right)$ aqueous species in $\mathrm{LiCl}-\mathrm{H}_{2} \mathrm{O}$ solutions vs. total molality of solutions at different temperatures. Results are given as mole percent of $\mathrm{LiCl}^{0}(\mathrm{aq})$, calculated as $100 \times \mathrm{m}\left(\mathrm{LiCl}^{0}(\mathrm{aq})\right) /\left[\mathrm{m}(\mathrm{LiCl}(\mathrm{aq}))+\mathrm{m}\left(\mathrm{LiCl}^{0}(\mathrm{aq})\right)\right]$, where $\mathrm{m}(\mathrm{LiCl}(\mathrm{aq}))=\mathrm{m}\left(\mathrm{Li}^{+}(\mathrm{aq})\right)=\mathrm{m}\left(\mathrm{Cl}^{-}(\mathrm{aq})\right)$.

Figure 8 - Model 2 predictions for the contribution of ionic $\left(\mathrm{Li}^{+}\right.$and $\mathrm{Cl}^{-}$, with $\mathrm{m}\left(\mathrm{Li}^{+}(\mathrm{aq})\right)=\mathrm{m}\left(\mathrm{Cl}^{-}(\mathrm{aq})\right)$ : long-dashed line) and neutral $\left(\mathrm{LiCl}^{0}(\mathrm{aq})\right.$ : short-dashed line) aqueous species on the total molality (solid line) of saturated $\mathrm{LiCl}-\mathrm{H}_{2} \mathrm{O}$ solutions (273.15 to $523.15 \mathrm{~K}$ ).

Figure 9 - Experimental aqueous (osmotic coefficient, $\varphi$ ) and solubility data used for the $\mathrm{LiOH}-\mathrm{H}_{2} \mathrm{O}$ binary system, as a function of temperature. Crosses represent aqueous data: from Nasirzadeh and others (2005) for 298.15 to $365.15 \mathrm{~K}$; from Mikulin (1968) at 298.15 K; from Holmes and Mesmer (1998a) for 383.25 to $443.09 \mathrm{~K}$. Black diamonds represent solubility data of $\mathrm{LiOH}(\mathrm{cr})$ and $\mathrm{LiOH} \mathrm{H}_{2} \mathrm{O}$ (cr) from compilations of Linke (1965), Zdanovskii and others (1973), from 273.15 to $373.15 \mathrm{~K}$. Triangles represent phase transition $\left(382.05 \mathrm{~K}\right.$ : $\mathrm{LiOH} . \mathrm{H}_{2} \mathrm{O}(\mathrm{cr})$ to $\mathrm{LiOH}(\mathrm{cr})$ ) point of Kirgintsev and others (1972). Grey diamonds represent high temperature $(423.15 \mathrm{~K}$ and $473.15 \mathrm{~K}) \mathrm{LiOH}(\mathrm{cr})$ solubility given by Itkina and others (1967). Circles represent $\mathrm{LiOH} . \mathrm{H}_{2} \mathrm{O}$ (cr) solubility at $273.15 \mathrm{~K}$ (Zdanovskii and others, 1973) (not included in parameterization).

Figure 10 - The calculated (lines) and experimental (symbols) osmotic coefficients $(\varphi)$ of $\mathrm{LiOH}-\mathrm{H}_{2} \mathrm{O}$ vs. molality $m$ of LiOH: at 273.15, 298.15, 348.15, 383.15, 443.15, and $473.15 \mathrm{~K}$. Closed triangles represent the smoothed data of Mikulin (1968) at $298.15 \mathrm{~K}$; open diamonds are data from Nasirzadeh and others (2005), at 298.15, 323.15, 348.15, and $363.15 \mathrm{~K}$;. open circles are data from Holmes and Mesmer (1998a) at $383.15,413.15$ and $443.15 \mathrm{~K}$. The dashed lines show extrapolations of the model to lower $(273.15 \mathrm{~K})$ and higher $(473.15 \mathrm{~K})$ temperatures.

Figure 11 - Experimental (symbols) and calculated (solid lines) solubility of $\mathrm{LiOH}(\mathrm{cr})$ and $\mathrm{LiOH}_{2} \mathrm{H}_{2} \mathrm{O}(\mathrm{cr})$ minerals vs. temperature in the $\mathrm{LiOH}-\mathrm{H}_{2} \mathrm{O}$ binary system. Experimental data - see figure 9 caption.

Figure 12 - Estimated $\beta^{(0)}\left(\mathrm{Li}^{+}, \mathrm{OH}^{-}\right)$(solid line), $\beta^{(1)}\left(\mathrm{Li}^{+}, \mathrm{OH}^{-}\right)$(long-dashed line), and $\mathrm{C}^{\varphi}\left(\mathrm{Li}^{+}, \mathrm{OH}^{-}\right)$(shortdashed line) pure electrolyte parameters for the $\mathrm{LiCl}-\mathrm{H}_{2} \mathrm{O}$ binary system from 273.15 to $523.15 \mathrm{~K}$.

Figure 13 - Comparison of the thermodynamic solubility product (as $\log \mathrm{K}_{\mathrm{sp}}^{\mathrm{o}}$ ) of lithium hydroxide solids determined for $\mathrm{LiOH}_{2} \mathrm{H}_{2} \mathrm{O}(\mathrm{cr})$ (solid line) and $\mathrm{LiOH}(\mathrm{cr})$ (dashed line) with recommended values (symbols) from 273.15 to $523.15 \mathrm{~K}$. Triangles and diamonds represent $\log \mathrm{K}_{\text {sp }}^{\mathrm{o}}$ recommendations of Monnin and Dubois (2005) for $\mathrm{LiOH}_{2} \mathrm{H}_{2} \mathrm{O}(\mathrm{cr})$ and $\mathrm{LiOH}(\mathrm{cr})$, respectively.

Figure 14 - Calculated mean $\mathrm{LiOH}$ activity coefficients in $\mathrm{LiOH}-\mathrm{H}_{2} \mathrm{O}$ solutions vs. molality, from 273.15 to $473.15 \mathrm{~K}$. The grey solid line represents the solubility of $\mathrm{LiOH} . n \mathrm{H}_{2} \mathrm{O}(n=0$ or 1$)$ solids (see figure 11).

Figure 15 - Experimental (symbols) and calculated (solid lines) solubility data for the $\mathrm{LiCl}-\mathrm{LiOH}-\mathrm{H}_{2} \mathrm{O}$ mixed system: A) at 273.15 and $323.15 \mathrm{~K}$; B) model prediction at $298.15 \mathrm{~K}$. On figure A), diamonds are experimental data at $273.15 \mathrm{~K}$ and triangles are data at $323.15 \mathrm{~K}$. Grey and black symbols are invariant experimental data. The solubility data are from Chernyh and others (1987). Experiments at $323.15 \mathrm{~K}$ show that a solid phase $\mathrm{LiCl} . \mathrm{LiOH}(\mathrm{cr})$ precipitates from saturated mixed solutions, while the calculated stable phase diagram consists in a field of $\mathrm{LiOH}: 3 \mathrm{LiCl}(\mathrm{cr})$ precipitation.

Figure 16 - Experimental (symbols) and calculated (lines) solubility of $\mathrm{LiCl} .2 \mathrm{H}_{2} \mathrm{O}$ (cr) and $\mathrm{LiCl} \cdot \mathrm{H}_{2} \mathrm{O}$ (cr) minerals at $273.15,293.15$ and $298.15 \mathrm{~K}$ in the $\mathrm{LiCl}-\mathrm{HCl}-\mathrm{H}_{2} \mathrm{O}$ ternary system. Experimental data are from Chu and Zai (1965) (white diamonds) and Engel (1888) (grey diamonds) at 273.15 K; from Li and others (2000) (black circles) at $293.15 \mathrm{~K}$; from Herz (1912) (white triangles) at $298.15 \mathrm{~K}$. The 
experimental eutonic point at $273.15 \mathrm{~K}$ (Chu and Zai, 1965) is indicated by the black diamond. The calculated eutonic point at $293.15 \mathrm{~K}$ is indicated by the white circle. Calculated solubility is extrapolated up to $373.15 \mathrm{~K}$ for $\mathrm{LiCl}(\mathrm{cr})$.

Figure 17 - The estimated ternary interaction parameters $\lambda\left(\mathrm{OH}^{-}, \mathrm{LiCl}^{0}\right)$ (dot-dashed line), $\psi\left(\mathrm{Li}^{+}, \mathrm{OH}^{-}, \mathrm{Cl}^{-}\right)$ (short-dashed line) and $\zeta\left(\mathrm{Li}^{+}, \mathrm{OH}^{-}, \mathrm{LiCl}^{\circ}\right)$ (long-dashed line) in the electrolytic aqueous mixture LiCl$\mathrm{LiOH}-\mathrm{H}_{2} \mathrm{O}$, from 273.15 to $473.15 \mathrm{~K}$, and extrapolated up to $523.15 \mathrm{~K}$. The ternary interaction parameter $\theta\left(\mathrm{OH}^{-}, \mathrm{Cl}^{-}\right)$(solid line) is from Christov and Møller (2004b).

Figure 18 - The estimated ternary interaction parameters $\theta\left(\mathrm{Li}^{+}, \mathrm{H}^{+}\right)$(solid line) and $\psi\left(\mathrm{Li}^{+}, \mathrm{H}^{+}, \mathrm{Cl}^{-}\right)$(longdashed line) in the electrolytic aqueous mixture $\mathrm{LiCl}-\mathrm{HCl}-\mathrm{H}_{2} \mathrm{O}$, from 273.15 to $298.15 \mathrm{~K}$, and extrapolated up to $373.15 \mathrm{~K}$.

Figure 19 - Osmotic coefficient, $\varphi$, for the $\mathrm{LiCl}-\mathrm{KCl}-\mathrm{H}_{2} \mathrm{O}$ ternary system vs. total molality $(\mathrm{mLiCl}+$ $\mathrm{mKCl}$ ) at $298.15 \mathrm{~K}$ for three different $\mathrm{Li} / \mathrm{K}$ ratios. Symbols represent experimental data from El Guendouzi and others (2003): $\mathrm{Li} / \mathrm{K}=0.5$ (white diamonds); $\mathrm{Li} / \mathrm{K}=1$ (black triangles); $\mathrm{Li} / \mathrm{K}=2$ (white circles). Lines represent calculated values for the same $\mathrm{Li} / \mathrm{K}$ ratios: $\mathrm{Li} / \mathrm{K}=0.5$ (solid line); $\mathrm{Li} / \mathrm{K}=1$ (longdashed line); $\mathrm{Li} / \mathrm{K}=2$ (short-dashed line).

Figure 20 - Experimental (symbols) and calculated (lines) solubility data for the LiCl-KCl- $\mathrm{H}_{2} \mathrm{O}$ mixed system: A) at 273.15 and $283.15 \mathrm{~K}$ for $\mathrm{LiCl} .2 \mathrm{H}_{2} \mathrm{O}$ (cr) and sylvite, B) at $298.15,323.15$, and $348.15 \mathrm{~K}$ for LiCl. $\mathrm{H}_{2} \mathrm{O}(\mathrm{cr})$ and sylvite, and $\mathrm{C}$ ) at $373.15 \mathrm{~K}$ for $\mathrm{LiCl}(\mathrm{cr})$ and sylvite. Experimental data are from the compilation of Zdanovskii and others (1973): on A), from Plyushchev and others (1959) (white diamonds) and Akopov (1962) (grey diamonds) at $273.15 \mathrm{~K}$, and from Akopov (1962) (white triangles) at $283.15 \mathrm{~K}$; on B), from Campbell and Kartzmark (1956) (grey triangles), Zatloukal and others (1959) (white triangles), Akopov (1962) (stars), and Plyushchev and others (1959) (black triangles) at 298.15 K, and from Plyushchev and others (1959) at 323.15 K (black diamonds) and $348.15 \mathrm{~K}$ (white squares); on C), data are from Yanko and Goldanel (1964).

Figure 21 - Estimated ion-interaction $\theta\left(\mathrm{Li}^{+}, \mathrm{K}^{+}\right)$(short-dashed line) and $\psi\left(\mathrm{Li}^{+}, \mathrm{K}^{+}, \mathrm{Cl}^{-}\right)$(long-dashed line) mixing parameters, and neutral specie-ion interaction $\lambda\left(\mathrm{K}^{+}, \mathrm{LiCl}^{0}\right)$ (solid line) and $\zeta\left(\mathrm{K}^{+}, \mathrm{Cl}^{-}, \mathrm{LiCl}^{0}\right)$ (dotdashed line) for the $\mathrm{LiCl}-\mathrm{KCl}-\mathrm{H}_{2} \mathrm{O}$ from 273.15 to $523.15 \mathrm{~K}$. Smaller short-dashed lines represent temperature extrapolation of the mixed $\mathrm{LiCl}-\mathrm{KCl}-\mathrm{H}_{2} \mathrm{O}$ model at $\mathrm{T}>373.15 \mathrm{~K}$.

Figure 22 - Osmotic coefficient, $\varphi$, for the $\mathrm{LiCl}-\mathrm{NaCl}-\mathrm{H}_{2} \mathrm{O}$ ternary system vs. $\mathrm{LiCl}$ molality at $298.15 \mathrm{~K}$ for three different $\mathrm{Li} / \mathrm{Na}$ ratios. Symbols represent experimental data from El Guendouzi and others (2004): closed grey diamonds, $\mathrm{Li} / \mathrm{Na}=0.5$; open squares, $\mathrm{Li} / \mathrm{Na}=1$; closed grey circles, $\mathrm{Li} / \mathrm{Na}=2$. Lines represent calculated values for the same $\mathrm{Li} / \mathrm{Na}$ ratios: solid line, $\mathrm{Li} / \mathrm{Na}=0.5$; long-dashed line, $\mathrm{Li} / \mathrm{Na}=1$; short-dashed line, $\mathrm{Li} / \mathrm{Na}=2$.

Figure 23 - Experimental (symbols) and calculated (lines) solubility data for the $\mathrm{LiCl}-\mathrm{NaCl}-\mathrm{H}_{2} \mathrm{O}$ mixed system at $273.15 \mathrm{~K}$ for $\mathrm{LiCl} .2 \mathrm{H}_{2} \mathrm{O}(\mathrm{cr})$ and halite; at $298.15,323.15$, and $363.15 \mathrm{~K}$ for $\mathrm{LiCl}_{2} \mathrm{H}_{2} \mathrm{O}(\mathrm{cr})$ and halite; and at $373.15 \mathrm{~K}$ for $\mathrm{LiCl}(\mathrm{cr})$ and halite. A) In the full range of dissolved LiCl molality; B) detail in the 0 to 1 molal of dissolved LiCl. Experimental data (see the compilation of Zdanovskii and others, 1973) are from Akopov (1963) at 273.15 K, and from Khy (1960) at 298.15, 323.15, 363.15 and 373.15 K.

Figure 24 - Estimated ion-interaction $\theta\left(\mathrm{Li}^{+}, \mathrm{Na}^{+}\right)$(short-dashed line) and $\psi\left(\mathrm{Li}^{+}, \mathrm{Na}^{+}, \mathrm{Cl}^{-}\right)$(long-dashed line) mixing parameters, and neutral specie-ion interaction $\lambda\left(\mathrm{Na}^{+}, \mathrm{LiCl}^{0}\right)$ (solid line) and $\zeta\left(\mathrm{Na}^{+}, \mathrm{Cl}^{-}, \mathrm{LiCl}^{0}\right)($ dotdashed line) for $\mathrm{LiCl}-\mathrm{NaCl}-\mathrm{H}_{2} \mathrm{O}$ from 273.15 to $523.15 \mathrm{~K}$. Smaller short-dashed lines represent temperature extrapolation of the mixed $\mathrm{LiCl}-\mathrm{NaCl}-\mathrm{H}_{2} \mathrm{O}$ model at $373.15 \mathrm{~K}$. 
Figure 25 - Calculated saturation index $\left[\log \left(\mathrm{IAP} / \mathrm{K}^{\circ}{ }_{\mathrm{sp}}\right)\right]$ of halite (grey diamonds), sylvite (grey circles), $\mathrm{LiCl} .2 \mathrm{H}_{2} \mathrm{O}$, and $\mathrm{LiCl} . \mathrm{H}_{2} \mathrm{O}$ (black triangles) for experimentally measured aqueous compositions on the halite-sylvite equilibrium line vs. Li concentration relative to total $\mathrm{Cl}$ concentration, A) at $273.15 \mathrm{~K}, \mathrm{~B}$ ) at $298.15 \mathrm{~K}$, and C) at $323.15 \mathrm{~K}$. Grey symbols represent saturation indices calculated at the invariant points, where halite, sylvite and $\mathrm{LiCl} . n \mathrm{H}_{2} \mathrm{O}(n=1$ or 2$)$ are observed simultaneously. Experimental data are from Yanatieva (1947) at 273.15, 298.15, and 323.15 K, and from Campbell and Kartzmark (1956) at 298.15 K (see also the compilation of Zdanovskii and others, 1975).

Figure 26 - Experimental (symbols) and calculated (lines) solubility data for the LiOH-KOH- $\mathrm{H}_{2} \mathrm{O}$ mixed system, that is for $\mathrm{LiOH}_{2} \mathrm{H}_{2} \mathrm{O}(\mathrm{cr}), \mathrm{LiOH}(\mathrm{cr})$ and $\mathrm{KOH} . \mathrm{H}_{2} \mathrm{O}(\mathrm{cr})$, a) at $323.15 \mathrm{~K}$, b) at 373.15 and $423.15 \mathrm{~K}$, and c) extrapolated solubilities at low $(273.15$ and $298.15 \mathrm{~K})$ and high $(473.15 \mathrm{~K})$ temperatures. Experimental data (see the compilation of Zdanovskii and others, 1973) are from Itkina and others (1967) at $323.15 \mathrm{~K}$ and $373.15 \mathrm{~K}$, and from Itkina and others (1968) at $423.15 \mathrm{~K}$.

Figure 27 - Estimated ion-interaction $\psi\left(\mathrm{Li}^{+}, \mathrm{K}^{+}, \mathrm{OH}^{-}\right)$(solid line) and $\psi\left(\mathrm{Li}^{+}, \mathrm{Na}^{+}, \mathrm{OH}^{-}\right)$(dashed line) mixing parameters from 273.15 to $423.15 \mathrm{~K}$, extrapolated up to $523.15 \mathrm{~K}$.

Figure 28 - Experimental (symbols) and calculated (lines) $\mathrm{LiOH}_{2} \mathrm{H}_{2} \mathrm{O}(\mathrm{cr}), \mathrm{LiOH}(\mathrm{cr})$ and $\mathrm{NaOH}_{2} \mathrm{H}_{2} \mathrm{O}$ (cr) solubility in the LiOH-NaOH- $\mathrm{H}_{2} \mathrm{O}$ mixed system: a) at 273.15 and $303.15 \mathrm{~K}$, b) at 323.15 and $423.15 \mathrm{~K}$. Experimental data are from Evteeva (1965) at $303.15 \mathrm{~K}$, and from Itkina and others (1968) at $423.15 \mathrm{~K}$ (see also the compilation of Zdanovskii and others, 1973). The white symbols on the $\mathrm{x}$-axis indicate the $\mathrm{NaOH} . n \mathrm{H}_{2} \mathrm{O}$ (cr) $(n=1$ or 4$)$ solubility in the binary $\mathrm{NaOH}-\mathrm{H}_{2} \mathrm{O}$ system (Rollet and Cohen-Adad, 1964, and Christov and Møller, 2004b). 
A Pitzer model for the Li-H-Na-K-Cl-OH-H $\mathrm{H}_{2} \mathrm{O}$ mineral-aqueous solution system up to mineral saturation and high temperatures

\section{TABLES}


Table 1. Standard deviation $(\sigma)$ values of activity (osmotic coefficients $(\varphi)$ ) and solubility data in the Li-Na-K-Cl- $\mathrm{H}_{2} \mathrm{O}(m o d e l 2)$ and $\mathrm{Li}-\mathrm{Na}-\mathrm{K}-\mathrm{OH}-\mathrm{H}_{2} \mathrm{O}$ systems. $n$ is the number of experimental data points and $m(\mathrm{sat})$ is the molality of solutions saturated with the corresponding solid phase.

\begin{tabular}{|c|c|c|c|c|c|c|c|}
\hline \multicolumn{8}{|c|}{ ACTIVITY DATA } \\
\hline SYSTEM & Method $^{\mathrm{a}}$ & Type of data & $\mathrm{t}^{\circ} \mathrm{C}-\mathrm{t}^{\mathrm{o}} \mathrm{C}$ & Molality Range & Reference & $\sigma$ & $n^{\mathrm{b}}$ \\
\hline \multirow[t]{9}{*}{$\mathrm{LiCl}-\mathrm{H}_{2} \mathrm{O}$} & vap & $\varphi$ & 20,25 & $1-18$ & Kangro and Groeneveld (1962) & $\begin{array}{c}0.0666^{c} \\
0.0244\end{array}$ & 36 \\
\hline & iso & $\varphi$ & 25 & $m(\mathrm{LiCl}): 0.1-20.0$ & Robinson and Stokes (1949) & $\begin{array}{l}0.0672^{\mathrm{c}} \\
0.0263^{\mathrm{d}}\end{array}$ & 37 \\
\hline & comp & $\varphi$ & 25 & $m(\mathrm{LiCl}): 0.001-19.219$ & Hamer and Wu (1972) & $\begin{array}{l}0.0568^{\mathrm{c}} \\
0.0299^{\mathrm{d}}\end{array}$ & 43 \\
\hline & iso & $\varphi$ & 45 & $m(\mathrm{LiCl}): 0.6-2.2$ & Hellams and others (1965) & $\begin{array}{l}0.0275^{\mathrm{c}} \\
0.0104^{\mathrm{d}}\end{array}$ & 11 \\
\hline & iso & $\varphi$ & 80 & $m(\mathrm{LiCl}): 1.3-4.8$ & Moore and others (1972) & $\begin{array}{l}0.0418^{\mathrm{c}} \\
0.0133^{\mathrm{d}}\end{array}$ & 14 \\
\hline & iso & $\varphi$ & $0-100$ & $m(\mathrm{LiCl}): 0.1-18.6$ & $\begin{array}{c}\text { Gibbard and Scatchard (1973), } \\
\text { Patil and others (1990) }\end{array}$ & $\begin{array}{l}0.0744^{\mathrm{c}} \\
0.0241^{\mathrm{d}}\end{array}$ & 130 \\
\hline & iso & $\varphi$ & $110-200$ & $m(\mathrm{LiCl}): 0.5-6.0$ & Holmes and Mesmer (1981) & $\begin{array}{l}0.0347^{\mathrm{c}} \\
0.0121^{\mathrm{d}}\end{array}$ & 28 \\
\hline & iso & $\varphi$ & 155 & $m(\mathrm{LiCl}): 7.42-20.95$ & Brendler and Voigt (1994) & $\begin{array}{l}0.0714^{c} \\
0.0432^{d}\end{array}$ & 16 \\
\hline & iso & $\varphi$ & $225-250$ & $m(\mathrm{LiCl}): 0.68-6.30$ & Holmes and Mesmer (1983) & $\begin{array}{l}0.0187^{\mathrm{c}} \\
0.0061^{\mathrm{d}}\end{array}$ & 34 \\
\hline
\end{tabular}




\begin{tabular}{|c|c|c|c|c|c|c|c|c|c|}
\hline \multirow[t]{3}{*}{$\mathrm{LiOH}-\mathrm{H}_{2} \mathrm{O}$} & vap & $\varphi$ & $25-90$ & & $\imath(\mathrm{LiOH}): 0.07-4.77$ & \multicolumn{2}{|c|}{ Nasirzadeh and others (2005) } & 0.0114 & 308 \\
\hline & & $\varphi$ & 25 & \multicolumn{2}{|r|}{$m(\mathrm{LiOH}): 0.1-5.0$} & \multicolumn{2}{|r|}{ Mikulin (1968) } & 0.0333 & 21 \\
\hline & iso & $\varphi$ & $110-170$ & \multicolumn{2}{|r|}{$m(\mathrm{LiOH}): 0.62-7.22$} & \multicolumn{2}{|r|}{ Holmes and Mesmer (1998) } & 0.0102 & 54 \\
\hline $\mathrm{LiCl}-\mathrm{KCl}-\mathrm{H}_{2} \mathrm{O}$ & hyg & $\varphi$ & 25 & \multicolumn{2}{|c|}{$M(\mathrm{LiCl}+\mathrm{KCl}): 0.0-6.0$} & \multicolumn{2}{|r|}{$\begin{array}{c}\text { El Guendouzi and others } \\
(2003)\end{array}$} & 0.0218 & 45 \\
\hline $\mathrm{LiCl}-\mathrm{NaCl}-\mathrm{H}_{2} \mathrm{O}$ & hyg & $\varphi$ & 25 & \multicolumn{2}{|c|}{$M(\mathrm{LiCl}+\mathrm{NaCl}): 0.0-6.0$} & \multicolumn{2}{|r|}{$\begin{array}{l}\text { El Guendouzi and others } \\
(2004)\end{array}$} & 0.0362 & 45 \\
\hline \multicolumn{10}{|c|}{ SOLUBILITY DATA } \\
\hline SYSTEM & Method $^{\mathrm{a}}$ & Type of salt & \multicolumn{2}{|c|}{$\mathrm{t}^{\circ} \mathrm{C}-\mathrm{t}^{\circ} \mathrm{C}$} & \multicolumn{2}{|l|}{ Molality Range } & Reference & $\sigma^{\mathrm{e}}$ & $n$ \\
\hline \multirow[t]{4}{*}{$\mathrm{LiCl}-\mathrm{H}_{2} \mathrm{O}$} & sol & $\begin{array}{l}\mathrm{LiCl} .2 \mathrm{H}_{2} \mathrm{O}(\mathrm{cr}) \\
m \text { (sat) }\end{array}$ & \multicolumn{2}{|c|}{$0-20$} & \multicolumn{2}{|c|}{$m(\mathrm{LiCl}): 16.06-19.52$} & Linke (1965) & $\begin{array}{l}0.3081^{\mathrm{c}} \\
0.1556^{\mathrm{d}} \\
\end{array}$ & 5 \\
\hline & sol & $\begin{array}{l}\mathrm{LiCl} . \mathrm{H}_{2} \mathrm{O}(\mathrm{cr}) \\
m(\text { sat })\end{array}$ & \multicolumn{2}{|c|}{$19.4-99$} & \multicolumn{2}{|c|}{$m(\mathrm{LiCl}): 19.46-30.27$} & $\begin{array}{c}\text { Linke (1965), Farelo and } \\
\text { others }(2005)\end{array}$ & $\begin{array}{l}0.3359^{c} \\
0.1578^{d}\end{array}$ & 28 \\
\hline & sol & LiCl(cr) $m$ (sat) & \multicolumn{2}{|c|}{$96-160$} & \multicolumn{2}{|c|}{$m(\mathrm{LiCl}): 29.83-34.23$} & Linke (1965) & $\begin{array}{l}0.0193^{\mathrm{c}} \\
0.0089^{\mathrm{d}}\end{array}$ & 8 \\
\hline & sol & $\mathrm{LiCl}(\mathrm{cr}) m$ (sat) & \multicolumn{2}{|c|}{$200-25$} & \multicolumn{2}{|c|}{$m(\mathrm{LiCl}): 36.46-40.74$} & Monnin and others (2002) & $\begin{array}{l}0.1301^{\mathrm{c}} \\
0.0026^{\mathrm{d}} \\
\end{array}$ & 2 \\
\hline \multirow[t]{2}{*}{$\mathrm{LiOH}-\mathrm{H}_{2} \mathrm{O}$} & sol & $\begin{array}{c}\mathrm{LiOH} . \mathrm{H}_{2} \mathrm{O}(\mathrm{cr}) \\
m(\text { sat })\end{array}$ & \multicolumn{2}{|c|}{ 0-108.9 } & \multicolumn{2}{|l|}{$m(\mathrm{LiOH}): 4.97-7.98$} & $\begin{array}{c}\text { Linke (1965), Kirgintsev and } \\
\text { others (1972) }\end{array}$ & 0.2202 & 16 \\
\hline & sol & $\begin{array}{c}\mathrm{LiOH}(\mathrm{cr}) \\
m \text { (sat) }\end{array}$ & $\begin{array}{r}108 . \\
200\end{array}$ & & $m(\mathrm{LiOH}): 7.06-7.8$ & & $\begin{array}{c}\text { Itkina and others (1967), } \\
\text { Kirgintsev and others (1972) }\end{array}$ & 0.0001 & 3 \\
\hline
\end{tabular}




\begin{tabular}{|c|c|c|c|c|c|c|c|}
\hline $\mathrm{LiCl}-\mathrm{KCl}-\mathrm{H}_{2} \mathrm{O}$ & sol & $\begin{array}{l}\mathrm{LiCl} \cdot 2 \mathrm{H}_{2} \mathrm{O}(\mathrm{cr}) \\
\mathrm{LiCl} \cdot \mathrm{H}_{2} \mathrm{O}(\mathrm{cr}) \\
\mathrm{LiCl}(\mathrm{cr}) \\
\mathrm{KCl}(\mathrm{cr}) \text { Sylvite } \\
m \text { (sat) } \\
\end{array}$ & $0-100$ & $\begin{array}{l}m(\mathrm{LiCl}): 0-31.50 \\
m(\mathrm{KCl}): 0.0-7.46\end{array}$ & $\begin{array}{c}\text { Plyushchev and others (1959), } \\
\text { Akopov (1962), Campbell and } \\
\text { Kartzmark (1956), Zatloukal } \\
\text { and others (1959), Yanko and } \\
\text { Goldanel (1964) }\end{array}$ & 0.0686 & 181 \\
\hline $\mathrm{LiCl}-\mathrm{NaCl}-\mathrm{H}_{2} \mathrm{O}$ & sol & $\begin{array}{l}\mathrm{LiCl} \cdot 2 \mathrm{H}_{2} \mathrm{O}(\mathrm{cr}) \\
\mathrm{LiCl} \cdot \mathrm{H}_{2} \mathrm{O}(\mathrm{cr}) \\
\mathrm{LiCl}(\mathrm{cr}) \\
\mathrm{NaCl}(\mathrm{cr}) \mathrm{Halite} \\
m \text { (sat) }\end{array}$ & $0-100$ & $\begin{array}{c}m(\mathrm{LiCl}): 0-30.40 \\
m(\mathrm{NaCl}): 0.0-6.70\end{array}$ & Akopov (1963), Khy (1960) & 0.0730 & 56 \\
\hline $\mathrm{LiOH}-\mathrm{KOH}-\mathrm{H}_{2} \mathrm{O}$ & sol & $\begin{array}{c}\mathrm{LiOH} . \mathrm{H}_{2} \mathrm{O}(\mathrm{cr}), \\
\mathrm{LiOH}(\mathrm{cr}) \\
\mathrm{KOH} . \mathrm{H}_{2} \mathrm{O}(\mathrm{cr}) \\
m(\mathrm{sat})\end{array}$ & $0-150$ & $\begin{array}{c}m(\mathrm{LiOH}): 0-7.85 \\
m(\mathrm{KOH}): 0.0-30.0\end{array}$ & Itkina and others $(1967,1968)$ & 0.0964 & 18 \\
\hline $\mathrm{LiOH}-\mathrm{NaOH}-\mathrm{H}_{2} \mathrm{O}$ & sol & $\begin{array}{c}\mathrm{LiOH} . \mathrm{H}_{2} \mathrm{O}(\mathrm{cr}) \\
\mathrm{LiOH}(\mathrm{cr}) \\
\mathrm{NaOH} . \mathrm{H}_{2} \mathrm{O}(\mathrm{cr}) \\
\mathrm{NaOH} .4 \mathrm{H}_{2} \mathrm{O}(\mathrm{cr}) \\
m \text { (sat) }\end{array}$ & $0-150$ & $\begin{array}{c}m(\mathrm{LiOH}): 0-7.85 \\
m(\mathrm{NaOH}): 0.0-20.0\end{array}$ & $\begin{array}{c}\text { Evteeva }(1965), \text { Itkina and } \\
\text { others }(1968)\end{array}$ & 0.1081 & 22 \\
\hline
\end{tabular}

${ }^{a}$ Experimental method: iso = isopiestic; comp = compilation; v.p. = vapor pressure; hyg = hygroscopic; sol = salt solubility.

${ }^{\mathrm{b}}$ Some of the experimental data are not used in the parameterization as explained in the text.

${ }^{\mathrm{c}}$ Standard deviation calculated for model 1 (without $\operatorname{LiCl}^{0}(\mathrm{aq})$ species)

${ }^{\mathrm{d}}$ Standard deviation calculated for model 2 (with $\mathrm{LiCl}^{0}(\mathrm{aq})$ species)

${ }^{\mathrm{e}}$ Average saturation index $=\left[\sum(\mathrm{SI})^{2} / \mathrm{n}\right]^{0.5}$; where $\mathrm{SI}=\log \left(\mathrm{IAP} / \mathrm{K}_{\mathrm{sp}}^{\circ}\right)$ is the saturation index of a mineral

Information in italics: data excluded from parameterization (see text) 
Table 2. Fitting constant values (eq 7) for the binary solution interaction parameters ${ }^{\mathrm{a}}$

\begin{tabular}{|c|c|c|c|c|c|c|c|}
\hline \multirow[t]{2}{*}{ Binary system } & \multirow[t]{2}{*}{ Parameters } & \multirow{2}{*}{$\begin{array}{l}\text { T range } \\
\left({ }^{\circ} \mathrm{C}\right)\end{array}$} & \multicolumn{5}{|c|}{ Constants ( $\mathrm{T}$ in degrees Kelvin) } \\
\hline & & & $a_{1}(-)$ & $a_{2}(T)$ & $a_{3}\left(T^{2}\right)$ & $a_{5}(1 / T)$ & $\mathrm{a}_{6}(\ln (\mathrm{T}))$ \\
\hline $\mathrm{LiCl}-\mathrm{H}_{2} \mathrm{O}$ & $\beta^{(0)}\left(\mathrm{Li}^{+}-\mathrm{Cl}^{-}\right)$ & $0-220$ & 0.5015472 & $-2.206 \mathrm{~d}-03$ & $2.349 \mathrm{~d}-06$ & 45.28407 & 0 \\
\hline \multirow[t]{3}{*}{ Model $1^{\mathrm{b}}$} & $\beta^{(1)}\left(\mathrm{Li}^{+}-\mathrm{Cl}^{-}\right)$ & $0-220$ & 13.21831 & -0.071394 & $8.772 d-05$ & 85.25804 & 0 \\
\hline & $\beta^{(2)}\left(\mathrm{Li}^{+}-\mathrm{Cl}^{-}\right)$ & $0-220$ & -6.01484 & 0.030441 & $-3.530 \mathrm{~d}-05$ & & \\
\hline & $\mathrm{C}^{\varphi}\left(\mathrm{Li}^{+}-\mathrm{Cl}^{-}\right)$ & $0-220$ & -0.02991 & $9.91 d-05$ & $-9.60 d-08$ & 1.51258 & 0 \\
\hline $\mathrm{LiCl}-\mathrm{H}_{2} \mathrm{O}$ & $\beta^{(0)}\left(\mathrm{Li}^{+}-\mathrm{Cl}^{-}\right)$ & $0-250$ & 0.2185836 & $-2.51 d-04$ & 0 & 9.696362 & 0 \\
\hline \multirow[t]{2}{*}{ Model $2^{\mathrm{c}}$} & $\beta^{(1)}\left(\mathrm{Li}^{+}-\mathrm{Cl}^{-}\right)$ & $0-250$ & -0.583294 & $2.165 \mathrm{~d}-03$ & 0 & 3.722014 & 0 \\
\hline & $\mathrm{C}^{\varphi}\left(\mathrm{Li}^{+}-\mathrm{Cl}^{-}\right)$ & $0-250$ & -0.01755 & $1.64 d-05$ & 0 & 3.56052 & 0 \\
\hline \multirow[t]{3}{*}{$\mathrm{LiOH}-\mathrm{H}_{2} \mathrm{O}$} & $\beta^{(0)}\left(\mathrm{Li}^{+}-\mathrm{OH}^{-}\right)$ & $0-200$ & 0.121114 & $-3.45 d-04$ & 0 & 3.917769 & 0 \\
\hline & $\beta^{(1)}\left(\mathrm{Li}^{+}-\mathrm{OH}^{-}\right)$ & $0-200$ & 1.235033 & $-3.984 d-03$ & 0 & 101.9411 & 0 \\
\hline & $\mathrm{C}^{\varphi}\left(\mathrm{Li}^{+}-\mathrm{OH}^{-}\right)$ & $0-200$ & $1.00 \mathrm{~d}-10$ & $2.51 \mathrm{~d}-06$ & 0 & -0.51131 & 0 \\
\hline
\end{tabular}

${ }^{a}$ The constants $a_{4}, a_{7}$ and $a_{8}$ in equation (2) are zero for all of the above parameters. The temperature range for each parameter is the temperature range of experimental data used in model parameterization and/or validation.

${ }^{\mathrm{b}}$ Model 1 includes only $\mathrm{Li}^{+}$and $\mathrm{Cl}^{-}$aqueous species

${ }^{c}$ Model 2 includes the three aqueous species $\mathrm{Li}^{+}, \mathrm{Cl}^{-}$and neutral $\mathrm{LiCl}$,aq 
Table 3. Values of fitting constants (eq 6) for $\log \mathrm{K}$ of formation of aqueous complex and dissolution of solid phases

\begin{tabular}{|c|c|c|c|c|c|c|c|}
\hline & \multirow[t]{2}{*}{ Compound } & \multirow{2}{*}{$\begin{array}{l}\text { T range } \\
\left({ }^{\circ} \mathrm{C}\right)^{\mathrm{a}}\end{array}$} & \multicolumn{5}{|c|}{ Constants ( $\mathrm{T}$ in degrees Kelvin) } \\
\hline & & & $\mathrm{A}_{1}(-)$ & $\mathrm{A}_{2}(\mathrm{~T})$ & $\mathrm{A}_{3}(1 / \mathrm{T})$ & $\mathrm{A}_{4}(\log \mathrm{T})$ & $A_{5}\left(1 / T^{2}\right)$ \\
\hline \multirow{3}{*}{ Model 1} & $\mathrm{LiCl} .2 \mathrm{H}_{2} \mathrm{O}, \mathrm{cr}$ & $0-20$ & 160.892123 & 0.11350914 & 1.1932293 & -76.955468 & 0 \\
\hline & $\mathrm{LiCl} . \mathrm{H}_{2} \mathrm{O}, \mathrm{cr}$ & $0-110$ & 19.720829 & -0.0036038 & 1.1316800 & -5.410474 & 0 \\
\hline & $\mathrm{LiCl}, \mathrm{cr}$ & $90-160$ & 14.6380406 & -0.0140304 & 1.2298564 & -1.458678 & 0 \\
\hline \multirow{7}{*}{ Model 2} & $\mathrm{LiCl}, \mathrm{aq}$ & $0-250$ & -3.5869 & 0.007566 & -1254.4 & 0 & 0 \\
\hline & $\mathrm{LiCl} .2 \mathrm{H}_{2} \mathrm{O}, \mathrm{cr}$ & $0-20$ & 6.1532 & -0.0064179 & 0 & 0 & 0 \\
\hline & $\mathrm{LiCl} . \mathrm{H}_{2} \mathrm{O}, \mathrm{cr}$ & $0-110$ & 36.2702 & 0.005655998 & 2.696341 & -13.2627354 & 0 \\
\hline & $\mathrm{LiCl}, \mathrm{cr}$ & $90-250$ & 29.9783 & -0.004068 & 1.15421 & -9.05005 & 0 \\
\hline & 3LiOH.LiCl,cr & 50 & 9.269 & 0 & 0 & 0 & 0 \\
\hline & LiOH.LiCl,cr & 50 & 6.593 & 0 & 0 & 0 & 0 \\
\hline & LiOH.3LiCl,cr & 50 & 17.95 & 0 & 0 & 0 & 0 \\
\hline & $\mathrm{LiOH} . \mathrm{H}_{2} \mathrm{O}, \mathrm{cr}$ & $0-110$ & -3.8702256 & -0.00914328 & 0.4129607 & 3.0072101 & 0 \\
\hline & $\mathrm{LiOH}, \mathrm{cr}$ & $50-200$ & -256.08895 & -0.06047962 & 9290.232715 & 98.8913449 & 142.35284 \\
\hline & Sylvite $^{b}$ & $0-250$ & 6.496259873 & -0.012323368 & -1537.997915 & 1.507740146 & -42632.32102 \\
\hline & Halite $^{c}$ & $0-250$ & -752.24954 & -0.11904958 & 41385.703 & 274.17933 & $-2480.9109 d+03$ \\
\hline
\end{tabular}




\begin{tabular}{|l|l|l|l|l|l|l|}
\hline KOH. $\mathrm{H}_{2} \mathrm{O}^{\mathrm{d}}$ & $0-70$ & -444.0232678 & -0.285906703 & -18.23476494 & 216.5607191 & 0.831249816 \\
\hline
\end{tabular}

${ }^{\text {a }}$ The temperature range of the solubility data used in parameter estimation and verification

${ }^{\mathrm{b}}$ Fitted using data of Greenberg and Møller (1989) for the sake of consistency with equation (6)

${ }^{\mathrm{c}}$ Taken from the Thermoddem database (Blanc and others, 2012)

${ }^{\mathrm{d}}$ Adapted to equation (6) using data of Christov and Møller (2004) 
Table 4. Molality and temperature of the invariant points in the $\mathrm{LiCl}-\mathrm{H}_{2} \mathrm{O}$ (Models 1 \& 2) and $\mathrm{LiOH}_{2} \mathrm{H}_{2} \mathrm{O}$ binary systems

\begin{tabular}{|c|c|c|c|c|}
\hline \multirow[t]{2}{*}{ Co-crystallization solids } & \multicolumn{2}{|c|}{$\begin{array}{c}m^{s} / \\
\left(m o l . k^{-1}\right)\end{array}$} & \multicolumn{2}{|c|}{$\mathrm{T} /{ }^{\circ} \mathrm{C}$} \\
\hline & Calculated & $\begin{array}{c}\text { Reference } \\
\text { data }\end{array}$ & Calculated & Reference data \\
\hline $\mathrm{LiCl} .2 \mathrm{H}_{2} \mathrm{O}(\mathrm{cr})+\mathrm{LiCl} . \mathrm{H}_{2} \mathrm{O}(\mathrm{cr})$ & $\begin{array}{l}\text { Model 1: } 19.34 \\
\text { Model 2: } 19.875\end{array}$ & $\begin{array}{l}19.57^{\mathrm{a}} \\
19.46^{\mathrm{b}} \\
19.46^{\mathrm{c}}\end{array}$ & $\begin{array}{l}\text { Model 1: } 19.02 \\
\text { Model 2: } 20.94\end{array}$ & $\begin{array}{l}20.79^{\mathrm{a}} \\
19.4^{\mathrm{b}} \\
20.0^{\mathrm{c}}\end{array}$ \\
\hline $\mathrm{LiCl} . \mathrm{H}_{2} \mathrm{O}(\mathrm{cr})+\mathrm{LiCl}(\mathrm{cr})$ & $\begin{array}{l}\text { Model 1: } 30.28 \\
\text { Model 2: } 30.03\end{array}$ & $\begin{array}{l}30.26^{\mathrm{a}} \\
30.27^{\mathrm{d}} \\
29.88^{\mathrm{c}}\end{array}$ & $\begin{array}{l}\text { Model 1: } 101.56 \\
\text { Model 2: } 96.97\end{array}$ & $\begin{array}{l}96.59^{\mathrm{a}} \\
96.0^{\mathrm{d}} \\
93.5 \pm 0.5^{\mathrm{c}} \\
93.51 \pm 0.03^{\mathrm{e}} \\
94.0^{\mathrm{f}}\end{array}$ \\
\hline 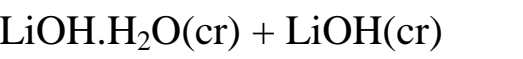 & 7.67 & $7.78^{\mathrm{g}}$ & 105.63 & $108.9^{\mathrm{g}}$ \\
\hline
\end{tabular}

${ }^{\mathrm{a}}$ Calculated using the MSA model of Monnin and others (2002); ${ }^{\mathrm{b}}$ Experimental values of Kessis (1961), included in the compilation of Kirgintsev and others (1972); ${ }^{c}$ Experimental values of Benrath (1934); ${ }^{d}$ Experimental values of Akopov (1962), included in the compilations of Kirgintsev and others (1972); ${ }^{\mathrm{e} P h a s e}$ Transition Temperature (PTT) given by Applebey and Cook (1938); ${ }^{\mathrm{f}} \mathrm{Phase}$ Transition Temperature (PTT) given in the compilation of Garrett (2004); ${ }^{\mathrm{g}}$ Experimental values of Rollet and Cohen-Adad (1964), included in the compilations of Kirgintsev and others (1972); 
Table 5. Predicted mean activity coefficient $\left(\gamma_{ \pm}\right)$of $\mathrm{LiCl}$ in binary solutions as a function of molality $\left(\mathrm{mol}_{\mathrm{kg}} \mathrm{kg}^{-1}\right)$ and temperature

\begin{tabular}{|c|c|c|c|c|c|c|c|c|c|}
\hline \multirow{2}{*}{$\begin{array}{l}\text { Recommended } \\
\text { values of: }\end{array}$} & \multirow[t]{2}{*}{$\mathrm{T} /{ }^{\circ} \mathrm{C}$} & \multicolumn{8}{|c|}{$\gamma_{ \pm}(\mathrm{LiCl})$} \\
\hline & & $\begin{array}{c}0.1 \\
\text { mol. } \mathrm{kg}^{-1}\end{array}$ & $\begin{array}{c}0.5 \\
\text { mol. } \mathrm{kg}^{-1}\end{array}$ & $\begin{array}{c}1.0 \\
\text { mol. } \mathrm{kg}^{-1}\end{array}$ & $\begin{array}{c}4.0 \\
\text { mol. } \mathrm{kg}^{-1}\end{array}$ & $\begin{array}{c}6.0 \\
\text { mol. } \mathrm{kg}^{-1}\end{array}$ & $\begin{array}{c}10.0 \\
\text { mol. } \mathrm{kg}^{-1}\end{array}$ & $\begin{array}{c}14.0 \\
\text { mol.kg }\end{array}$ & $\begin{array}{c}18.0 \\
\text { mol. } \mathrm{kg}^{-1}\end{array}$ \\
\hline Model $1^{1}$ & 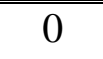 & 0.800 & 0.747 & 0.784 & 1.731 & 3.329 & 12.188 & 39.205 & 105.510 \\
\hline Model $2^{1}$ & & 0.780 & 0.714 & 0.751 & 1.657 & 3.128 & 11.925 & 42.656 & 88.062 \\
\hline Calc. $^{2}$ & & 0.800 & 0.758 & 0.792 & 1.636 & 3.117 & 12.51 & 41.4 & 87.94 \\
\hline Model $1^{1}$ & 25 & 0.764 & 0.680 & 0.703 & 1.477 & 2.635 & 8.031 & 21.518 & 49.254 \\
\hline Model $2^{1}$ & & 0.774 & 0.704 & 0.734 & 1.495 & 2.653 & 8.709 & 25.614 & 46.805 \\
\hline Calc. $^{2}$ & & 0.794 & 0.741 & 0.782 & 1.501 & 2.697 & 9.333 & 25.94 & 49.14 \\
\hline Calc. ${ }^{3}$ & & 0.790 & 0.739 & 0.774 & 1.510 & 2.72 & 9.40 & 26.2 & \\
\hline Calc. ${ }^{4}$ & & 0.789 & 0.739 & 0.775 & 1.499 & 2.73 & 9.60 & 25.5 & 50.3 \\
\hline Calc. $^{5}$ & & 0.790 & 0.739 & 0.774 & 1.51 & 2.72 & 9.40 & 26.2 & 49.9 \\
\hline Calc. $^{6}$ & & & 0.739 & 0.770 & 1.495 & 2.717 & & & \\
\hline Model $1^{1}$ & 50 & 0.734 & 0.626 & 0.640 & 1.279 & 2.137 & 5.570 & 12.82 & 25.733 \\
\hline Model $2^{1}$ & & 0.767 & 0.692 & 0.714 & 1.349 & 2.263 & 6.506 & 16.195 & 26.736 \\
\hline Calc. $^{2}$ & & 0.783 & 0.722 & 0.746 & 1.357 & 2.308 & 6.973 & 16.68 & 28.81 \\
\hline Model $1^{1}$ & 100 & 0.685 & 0.548 & 0.547 & 0.976 & 1.454 & 2.945 & 5.357 & 8.832 \\
\hline Model $2^{1}$ & & 0.745 & 0.657 & 0.661 & 1.078 & 1.632 & 3.726 & 7.128 & 10.116 \\
\hline Calc. $^{2}$ & & 0.756 & 0.676 & 0.681 & 1.088 & 1.665 & 3.889 & 7.155 & 10.52 \\
\hline
\end{tabular}




\begin{tabular}{|l|l|l|l|l|l|l|l|l|l|}
\hline Model 1 $^{1}$ & 140 & 0.656 & 0.506 & 0.494 & 0.788 & 1.083 & 1.872 & 2.967 & 4.372 \\
Model 2 $^{1}$ & & 0.721 & 0.618 & 0.608 & 0.879 & 1.235 & 2.399 & 3.924 & 5.115 \\
Calc. $^{7}$ & & & 0.626 & 0.616 & 0.889 & 1.273 & & & \\
\hline $\begin{array}{l}\text { Model 1 } \\
\text { Model 2 }\end{array}$ & 170 & 0.638 & 0.483 & 0.463 & 0.667 & 0.864 & 1.353 & 1.977 & 2.727 \\
Calc. $^{7}$ & 0.698 & 0.584 & 0.562 & 0.740 & 0.983 & 1.711 & 2.552 & 3.173 \\
\hline $\begin{array}{l}\text { Model 1 } \\
\text { Model 2 }\end{array}$ & & & 0.587 & 0.566 & 0.753 & 1.028 & & & \\
Calc. $^{7}$ & 200 & 0.622 & 0.464 & 0.436 & 0.557 & 0.681 & 0.978 & 1.337 & 1.747 \\
\hline
\end{tabular}

${ }^{1}$ Predictions of models No.1 and No.2 presented here (see Table 2); ${ }^{2}$ Predictions of the model of Gibbard and Scatchard (1973)

${ }^{3}$ Recommended values of Robinson and Stokes (1949); ${ }^{4}$ Recommended values of Hamer and Wu (1972); Recommended values of Mikulin (1968); ${ }^{6}$ Predictions of the model of El Guendouzi and others (2001); ${ }^{7}$ Predictions of the model of Holmes and Mesmer (1981) 
Table 6. Predicted mean activity coefficient $\left(\gamma_{ \pm}\right)$of LiOH in binary solutions as a function of molality $\left(m o l . \mathrm{kg}^{-1}\right)$ and temperature

\begin{tabular}{|c|c|c|c|c|c|c|c|c|}
\hline \multirow{2}{*}{$\begin{array}{l}\text { Recommended } \\
\text { values of: }\end{array}$} & \multirow[t]{2}{*}{$\mathrm{t}^{\circ} \mathrm{C}$} & \multicolumn{7}{|c|}{$\gamma_{ \pm}(\mathrm{LiOH})$} \\
\hline & & $\begin{array}{c}0.1 \\
\text { mol.kg }\end{array}$ & $\begin{array}{c}0.5 \\
\text { mol. } \mathrm{kg}^{-1}\end{array}$ & $\begin{array}{c}1.0 \\
\text { mol. } \mathrm{kg}^{-1}\end{array}$ & $\begin{array}{c}2.0 \\
\text { mol. } \mathrm{kg}^{-1}\end{array}$ & $\begin{array}{c}3.0 \\
\text { mol. } \mathrm{kg}^{-1}\end{array}$ & $\begin{array}{c}4.0 \\
\text { mol. } \mathrm{kg}^{-1}\end{array}$ & $\begin{array}{c}5.0 \\
\text { mol. } \mathrm{kg}^{-1}\end{array}$ \\
\hline This study $^{1}$ & $\overline{00}$ & 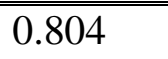 & $\bar{~} 0.727$ & 0.697 & 0.670 & 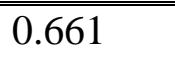 & 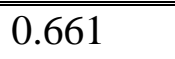 & 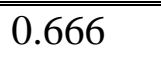 \\
\hline Calc. $^{2}$ & & 0.757 & 0.612 & 0.551 & 0.503 & 0.487 & 0.487 & 0.497 \\
\hline "This study ${ }^{1}$ & 25 & 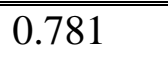 & 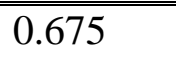 & 0.629 & $\begin{array}{c}0.584 \\
\end{array}$ & 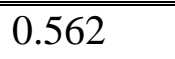 & 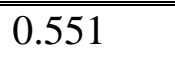 & 0.545 \\
\hline Calc. $^{2}$ & & 0.766 & 0.607 & 0.548 & 0.502 & 0.485 & 0.481 & 0.484 \\
\hline Calc. ${ }^{3}$ & & 0.946 & & 0.749 & 0.697 & 0.671 & & \\
\hline Calc. ${ }^{4}$ & & 0.76 & 0.617 & 0.554 & 0.513 & 0.494 & 0.481 & \\
\hline Calc. $^{5}$ & & 0.735 & 0.579 & 0.522 & 0.484 & 0.469 & 0.457 & 0.493 \\
\hline Calc. ${ }^{6}$ & & 0.718 & 0.583 & 0.523 & 0.485 & 0.467 & 0.454 & 0.456 \\
\hline This study $^{1}$ & 50 & 0.757 & 0.625 & 0.566 & 0.507 & 0.476 & 0.457 & 0.443 \\
\hline Calc. $^{2}$ & & 0.738 & 0.586 & 0.521 & 0.466 & 0.440 & 0.426 & 0.417 \\
\hline Calc. $^{3}$ & & 0.894 & & 0.675 & 0.613 & 0.575 & & \\
\hline This study ${ }^{1}$ & 100 & 0.705 & 0.528 & 0.449 & 0.374 & 0.333 & 0.305 & 0.285 \\
\hline Calc. $^{2}$ & & 0.705 & 0.527 & 0.446 & 0.370 & 0.328 & 0.301 & 0.280 \\
\hline This study $^{1}$ & 200 & 0.585 & 0.349 & 0.257 & 0.181 & 0.143 & 0.118 & 0.101 \\
\hline Calc. $^{2}$ & & 0.607 & 0.384 & 0.289 & 0.203 & 0.159 & 0.133 & 0.115 \\
\hline This study $^{1}$ & 250 & 0.514 & 0.265 & 0.179 & 0.113 & 0.083 & 0.065 & 0.053 \\
\hline
\end{tabular}




\begin{tabular}{|l|l|l|l|l|l|l|l|l|}
\hline Calc. $^{2}$ & & 0.534 & 0.301 & 0.211 & 0.1357 & 0.101 & 0.081 & 0.069 \\
\hline
\end{tabular}

${ }^{1}$ Predictions of the model presented here; ${ }^{2}$ Predictions of the model of Holmes and Mesmer (1998); ${ }^{3}$ Recommended values of the model of Nasirzadeh and others (2005) at $(0.124,1,01,1.99$, and 3.106$) m ;{ }^{4}$ Recommended values of Robinson and Stokes (1949);

${ }^{5}$ Recommended values of Hamer and Wu (1972); ${ }^{6}$ Recommended values of Mikulin (1968) 
Table 7. Comparison of model calculations and experimental or recommended values for the activity properties in saturated (s) Lithium binary solutions at $\mathrm{T}=298.15 \mathrm{~K}$ : Deliquescence Relative Humidity DRH (DRH $\left.=a_{\mathrm{w}}{ }^{\mathrm{s}} \times 100\right) ; a_{\mathrm{w}}{ }^{\mathrm{s}}, \varphi^{\mathrm{s}}$ and $\gamma^{\mathrm{s}}$, activity of water, osmotic and activity coefficients at saturation, respectively.

\begin{tabular}{|c|c|c|c|c|c|c|c|c|c|}
\hline \multirow{3}{*}{ Binary System } & \multicolumn{3}{|c|}{ DRH, $\%\left(a_{\mathrm{w}}{ }^{\mathrm{s}} \times 100\right)$} & \multicolumn{3}{|c|}{$\varphi^{\mathrm{s}}$} & \multicolumn{3}{|c|}{$\gamma^{\mathrm{s}}$} \\
\hline & \multirow[t]{2}{*}{ Exp. data } & \multicolumn{2}{|c|}{ Calculated } & \multirow[t]{2}{*}{ Exp. data } & \multicolumn{2}{|c|}{ Calculated } & \multirow[t]{2}{*}{ Recom's } & \multicolumn{2}{|c|}{ Calculated } \\
\hline & & $\begin{array}{c}\text { Reference } \\
\text { models }\end{array}$ & This study ${ }^{\mathrm{g}}$ & & $\begin{array}{c}\text { Reference } \\
\text { models }\end{array}$ & This study ${ }^{\mathrm{g}}$ & & $\begin{array}{c}\text { Reference } \\
\text { models }\end{array}$ & This study ${ }^{\mathrm{g}}$ \\
\hline $\mathrm{LiCl}-\mathrm{H}_{2} \mathrm{O}$ & $\begin{array}{l}11.05^{\mathrm{a}} \\
11.3^{\mathrm{b}} \\
11.30^{\mathrm{c}}\end{array}$ & $\begin{array}{l}10.16^{\mathrm{d}} \\
10.12^{\mathrm{e}}\end{array}$ & $\begin{array}{l}\text { Model 1: } 9.576 \\
\text { Model 2: } 11.682\end{array}$ & $3.07^{\mathrm{a}}$ & $\begin{array}{l}3.184^{\mathrm{d}} \\
3.19^{\mathrm{e}}\end{array}$ & $\begin{array}{l}\text { Model 1: } 3.265 \\
\text { Model 2: } 2.956\end{array}$ & $\approx 62^{\mathrm{a}}$ & $\begin{array}{r}70.3^{\mathrm{e}} \\
>>100^{\mathrm{f}}\end{array}$ & $\begin{array}{l}\text { Model 1: } 69.311 \\
\text { Model 2: } 54.41\end{array}$ \\
\hline $\mathrm{LiOH}-\mathrm{H}_{2} \mathrm{O}$ & $83.4^{\mathrm{a}}$ & $84.8^{f}$ & 83.823 & $0.934^{\mathrm{a}}$ & $0.848^{\mathrm{f}}$ & 0.920 & $0.461^{\mathrm{a}}$ & $0.42^{\mathrm{f}}$ & 0.544 \\
\hline
\end{tabular}

${ }^{a}$ Experimental data and recommendations of Mikulin (1968); ${ }^{b}$ DRH data at 294.75 K of Hedlin and Trofimenkoff (1965); ${ }^{\mathrm{c}}$ Smoothed DRH data of Greenspan (1977); ${ }^{\mathrm{d}}$ Data calculated using parameterization of Kim and Frederick (1988); ${ }^{\mathrm{e}}$ Data calculated using parameterization of Song and Yao (2001); ${ }^{\mathrm{f}}$ Data calculated using parameterization of Pitzer and Mayorga (1973); ${ }^{\mathrm{g}}$ Data calculated using chemical equilibrium models developed during this study using two different model parameterization approaches (see table 2). 
Table 8. Fitting constant values (eq 2) for the ternary solution interaction parameters ${ }^{\mathrm{a}}$

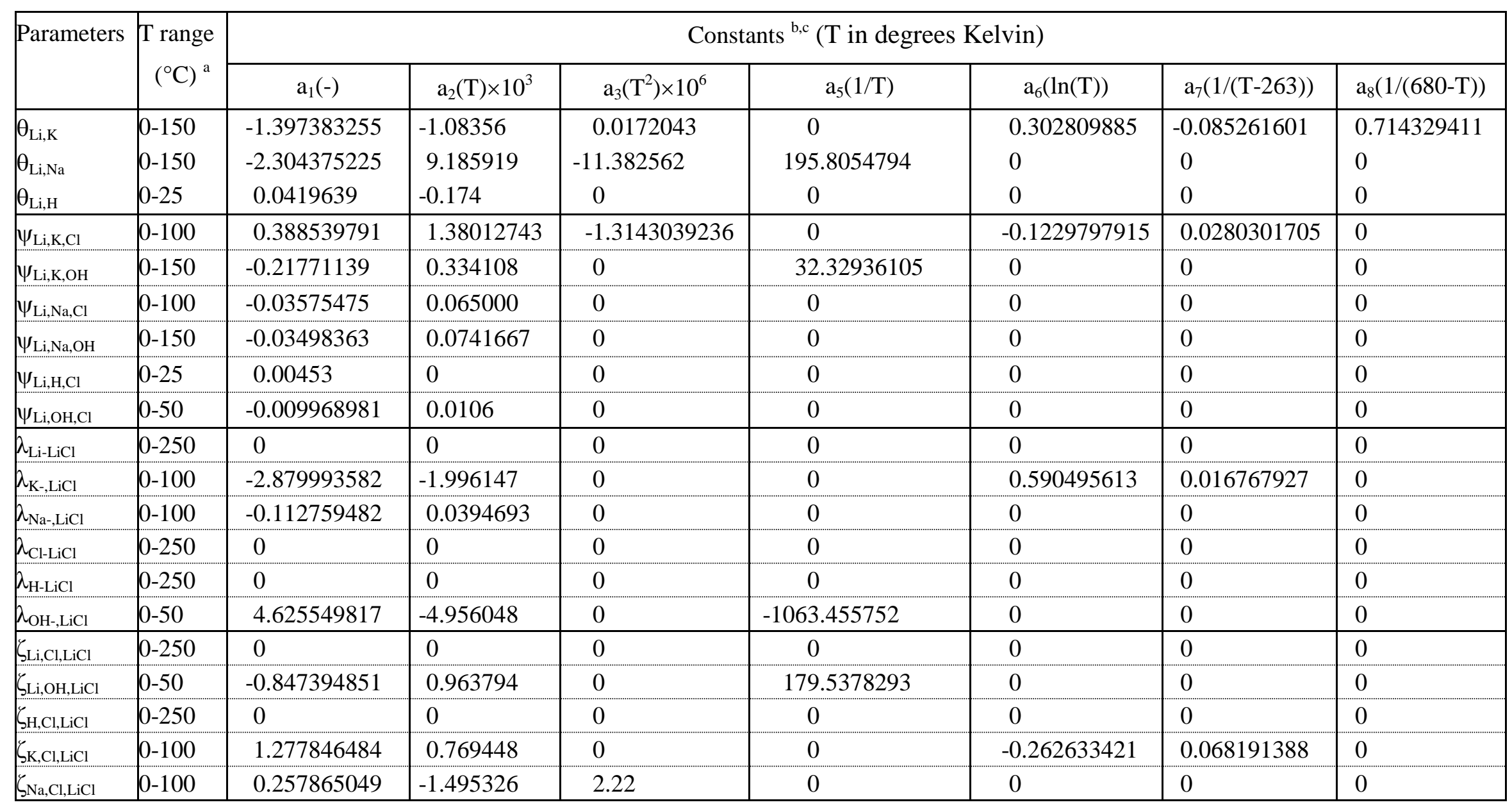

a The temperature range listed for each parameter is the temperature range of the experimental data used in model parameterization and/or validation. ${ }^{b}$ The constant $\mathrm{a}_{4}$ in equation (2) is zero for all of the above parameters. ${ }^{\mathrm{c}}$ The ternary parameters have been estimated only for model 2 of the $\mathrm{LiCl}-\mathrm{H}_{2} \mathrm{O}$ binary system (that is when the $\mathrm{LiCl}^{0}(\mathrm{aq})$ species is included) 


\section{References used in the tables.}

This list is already included in the list of references given at the end of the manuscript.

Akopov, E. K., 1962, Polytherms of solubility in the system LiCl-KCl-H ${ }_{2} \mathrm{O}$ : Russian Journal of Inorganic Chemistry, v. 7, p. 385-389.

-, 1963: Russian Journal of Physical Chemistry, v. 36, p. 1918.

Applebey, M., and Cook, R., 1938, The transition temperatures of lithium chloride hydrates: Journal of the Chemical Society (Resumed), p. 547.

Benrath, H., 1934, Die Polytherme des ternären Systems: $\mathrm{MnCl}_{2}-(\mathrm{LiCl})_{2}-\mathrm{H}_{2} \mathrm{O}$ : Zeitschrift für anorganische und allgemeine Chemie, v. 220, p. 145-153.

Blanc, P., Lassin, A., Piantone, P., Azaroual, M., Jacquemet, N., Fabbri, A., and Gaucher, E. C., 2012, Thermoddem: A geochemical database focused on low temperature water/rock interactions and waste materials: Applied Geochemistry, v. 27, p. 2107-2116.

Brendler, V., and Voigt, W., 1994, Isopiestic measurements at high temperatures. I. Aqueous solutions of $\mathrm{LiCl}, \mathrm{CsCl}$, and $\mathrm{CaCl}_{2}$ at $155^{\circ} \mathrm{C}$ : Journal of Solution Chemistry, v. 23, p. 1061-1072.

Campbell, A. N., and Kartzmark, E. M., 1956, The System LiCl-NaCl-KCl- $\mathrm{H}_{2} \mathrm{O}$ at $25^{\circ} \mathrm{C}$ : Canadian Journal of Chemistry, v. 34, p. 672-678.

Christov, C., and Møller, N., 2004, Chemical equilibrium model of solution behavior and solubility in the $\mathrm{H}-\mathrm{Na}-\mathrm{K}-\mathrm{OH}-\mathrm{Cl}-\mathrm{HSO}_{4}-\mathrm{SO}_{4}-\mathrm{H}_{2} \mathrm{O}$ system to high concentration and temperature: Geochimica et Cosmochimica Acta, v. 68, p. 1309-1331.

El Guendouzi, M., Benbiyi, A., Dinane, A., and Azougen, R., 2003, The thermodynamic study of the system $\mathrm{LiCl}-\mathrm{KCl}-\mathrm{H}_{2} \mathrm{O}$ at the temperature $298.15 \mathrm{~K}$ : Calphad, v. 27, p. 213-219.

-, 2004, Thermodynamic properties of multicomponent $\mathrm{NaCl}-\mathrm{LiCl}-\mathrm{H}_{2} \mathrm{O}$ aqueous solutions at temperature $298.15 \mathrm{~K}$ : Calphad, v. 28, p. 97-103.

El Guendouzi, M., Dinane, A., and Mounir, A., 2001, Water activities, osmotic and activity coefficients in aqueous chloride solutions at $\mathrm{T}=298.15 \mathrm{~K}$ by the hygrometric method: The Journal of Chemical Thermodynamics, v. 33, p. 10591072.

Evteeva, O. G., 1965: Izv. Sib. Otd. Akad. Nauk. SSSR, Ser. Khim. Nauk., v. 7, p. 144.

Farelo, F., Fernandes, C., and Avelino, A., 2005, Solubilities for Six Ternary Systems: $\mathrm{NaCl}+\mathrm{NH}_{4} \mathrm{Cl}+\mathrm{H}_{2} \mathrm{O}, \mathrm{KCl}+\mathrm{NH}_{4} \mathrm{Cl}+\mathrm{H}_{2} \mathrm{O}, \mathrm{NaCl}+\mathrm{LiCl}+\mathrm{H}_{2} \mathrm{O}, \mathrm{KCl}+\mathrm{LiCl}+$ $\mathrm{H}_{2} \mathrm{O}, \mathrm{NaCl}+\mathrm{AlCl}_{3}+\mathrm{H}_{2} \mathrm{O}$, and $\mathrm{KCl}+\mathrm{AlCl}_{3}+\mathrm{H}_{2} \mathrm{O}$ at $\mathrm{T}=(298$ to 333) $\mathrm{K}$ : Journal of Chemical \& Engineering Data, v. 50, p. 1470-1477.

Garrett, D. E., 2004, Handbook of lithium and natural calcium chloride. Their deposits, processing, uses and properties, Elsevier Academic Press, 476 p.

Gibbard, H. F., and Scatchard, G., 1973, Liquid-vapor equilibrium of aqueous lithium chloride, from 25 to $100 . \mathrm{deg}$. and from 1.0 to 18.5 molal, and related properties: Journal of Chemical \& Engineering Data, v. 18, p. 293-298.

Greenberg, J. P., and Møller, N., 1989, The prediction of mineral solubilities in natural waters: A chemical equilibrium model for the $\mathrm{Na}-\mathrm{K}-\mathrm{Ca}-\mathrm{Cl}-\mathrm{SO}_{4}-\mathrm{H}_{2} \mathrm{O}$ system to high concentration from 0 to $250^{\circ} \mathrm{C}$ : Geochimica et Cosmochimica Acta, v. 53, p. 2503-2518. 
Greenspan, L., 1977, Humidity fixed points of binary saturated aqueous solutions: Journal of Research of the National Bureau of Standards-Physics and Chemistry, v. 81A, p. 89-96.

Hamer, W. J., and Wu, Y.-C., 1972, Osmotic Coefficients and Mean Activity Coefficients of Uni-univalent Electrolytes in Water at $25^{\circ} \mathrm{C}$ : Journal of Physical and Chemical Reference Data, v. 1, p. 1047-1099.

Hedlin, C. P., and Trofimenkoff, F. N., 1965, Relative humidities over saturated solutions of nine salts in the temperature range from 0 to $90{ }^{\circ} \mathrm{F}$, International Symposium on Humidity and Moisture: Washington D.C., USA, 1963, National Research Council of Canada, p. 519-520.

Hellams, K., Paterson, C., Prentice, B., and Taylor, M., 1965, Osmotic Properties of Some Aqueous Solutions at $45^{\circ} \mathrm{C}$ : Journal of Chemical and Engineering Data, v. 10, p. 323-325.

Holmes, H. F., and Mesmer, R. E., 1981, Isopiestic studies of aqueous solutions at elevated temperatures VI. $\mathrm{LiCl}$ and $\mathrm{CsCl}$ : The Journal of Chemical Thermodynamics, v. 13, p. 1035-1046.

-, 1983, Thermodynamic Properties of Aqueous Solutions of the Alkali Metal Chlorides to $250^{\circ} \mathrm{C}$ : Journal of Physical Chemistry, v. 87 , p. 1242-1255.

-, 1998, Isopiestic molalities for aqueous solutions of the alkali metal hydroxides at elevated temperatures: The Journal of Chemical Thermodynamics, v. 30, p. 311326.

Itkina, L., Chaplighina, N., and Portnova, S., 1967: Russian Journal of Inorganic Chemistry, v. 12, p. 547.

Itkina, L., Portnova, S., and Chaplighina, N., 1968: Russian Journal of Inorganic Chemistry, v. 13, p. 1415.

Kangro, W., and Groeneveld, A., 1962, Konzentrierte wäßrige Lösungen, I: Zeitschrift für Physikalische Chemie Neue Folge, v. 32, p. 110-26.

Khy, K.-Y., 1960: Russian Journal of Physical Chemistry, v. 5, p. 190-192.

Kim, H. T., and Frederick, W. J., 1988, Evaluation of Pitzer ion interaction parameters of aqueous electrolytes at $25^{\circ} \mathrm{C}$. 1 . Single salt parameters: Journal of Chemical \& Engineering Data, v. 33, p. 177-184.

Kirgintsev, A. N., Trushnikova, L. N., and Lavrent'eva, V. G., 1972, Solubility of inorganic substances in water: St. Petersburg, Khimia, UDK, 541 p.

Linke, W., 1965, Solubilities of inorganic and metal-organic compounds, 4th Edition, v. 1 and 2: Washington, American Chemical Society.

Mikulin, G., 1968, Voprosy Fizicheskoi Khimii Electrolytov: St. Petersburg, Izd. Khimiya.

Monnin, C., Dubois, M., Papaiconomou, N., and Simonin, J.-P., 2002, Thermodynamics of the $\mathrm{LiCl}+\mathrm{H}_{2} \mathrm{O}$ System: Journal of Chemical \& Engineering Data, v. 47, p. 1331-1336.

Moore, J., Humphries, W., and Paterson, C., 1972, Isopiestic Studies of Some Aqueous Electrolyte Solutions at $80{ }^{\circ} \mathrm{C}$ : Journal of Chemical and Engineering Data, v. 17, p. $180-182$.

Nasirzadeh, K., Neueder, R., and Kunz, W., 2005, Vapor Pressures and Osmotic Coefficients of Aqueous LiOH Solutions at Temperatures Ranging from 298.15 to 363.15 K: Industrial \& Engineering Chemistry Research, v. 44, p. 3807-3814. 
Patil, K. R., Tripathi, A. D., Pathak, G., and Katti, S. S., 1990, Thermodynamic properties of aqueous electrolyte solutions. 1. Vapor pressure of aqueous solutions of lithium chloride, lithium bromide, and lithium iodide: Journal of Chemical \& Engineering Data, v. 35, p. 166-168.

Pitzer, K. S., and Mayorga, G., 1973, Thermodynamics of electrolytes. II. Activity and osmotic coefficients for strong electrolytes with one or both ions univalent: The Journal of Physical Chemistry, v. 77, p. 2300-2308.

Plyushchev, V. E., Kuznetsova, G. P., and Stepina, S. B., 1959: Zhurnal Neorganicheskoi Khimii, v. 4, p. 1450.

Robinson, R. A., and Stokes, R. H., 1949, Tables of osmotic and activity coefficients of electrolytes in aqueous solution at $25^{\circ} \mathrm{C}$ : Transactions of the Faraday Society, v. 45 , p. 612-624.

Rollet, A., and Cohen-Adad, R., 1964, Les systèmes "eau-hydroxide alcalin": Revue de Chimie Minérale, v. 1, p. 451.

Song, P., and Yao, Y., 2001, Thermodynamics and Phase Diagram of the Salt Lake Brine System at $25^{\circ} \mathrm{C} \mathrm{I}$. $\mathrm{Li}^{+}, \mathrm{K}^{+}, \mathrm{Mg}^{2+} / \mathrm{Cl}^{-}, \mathrm{SO}_{4}{ }^{2-},-\mathrm{H}_{2} \mathrm{O}$ System: Calphad, v. 25 , p. 329341.

Yanko, A. P., and Goldanel, A. Y., 1964: Izv. Phyz.-Khim, v. 6, p. 146.

Zatloukal, J., Jäger, L., Machala, J., and Jerman, Z., 1959: Chem. Průmysl, v. 9, p. 305. 


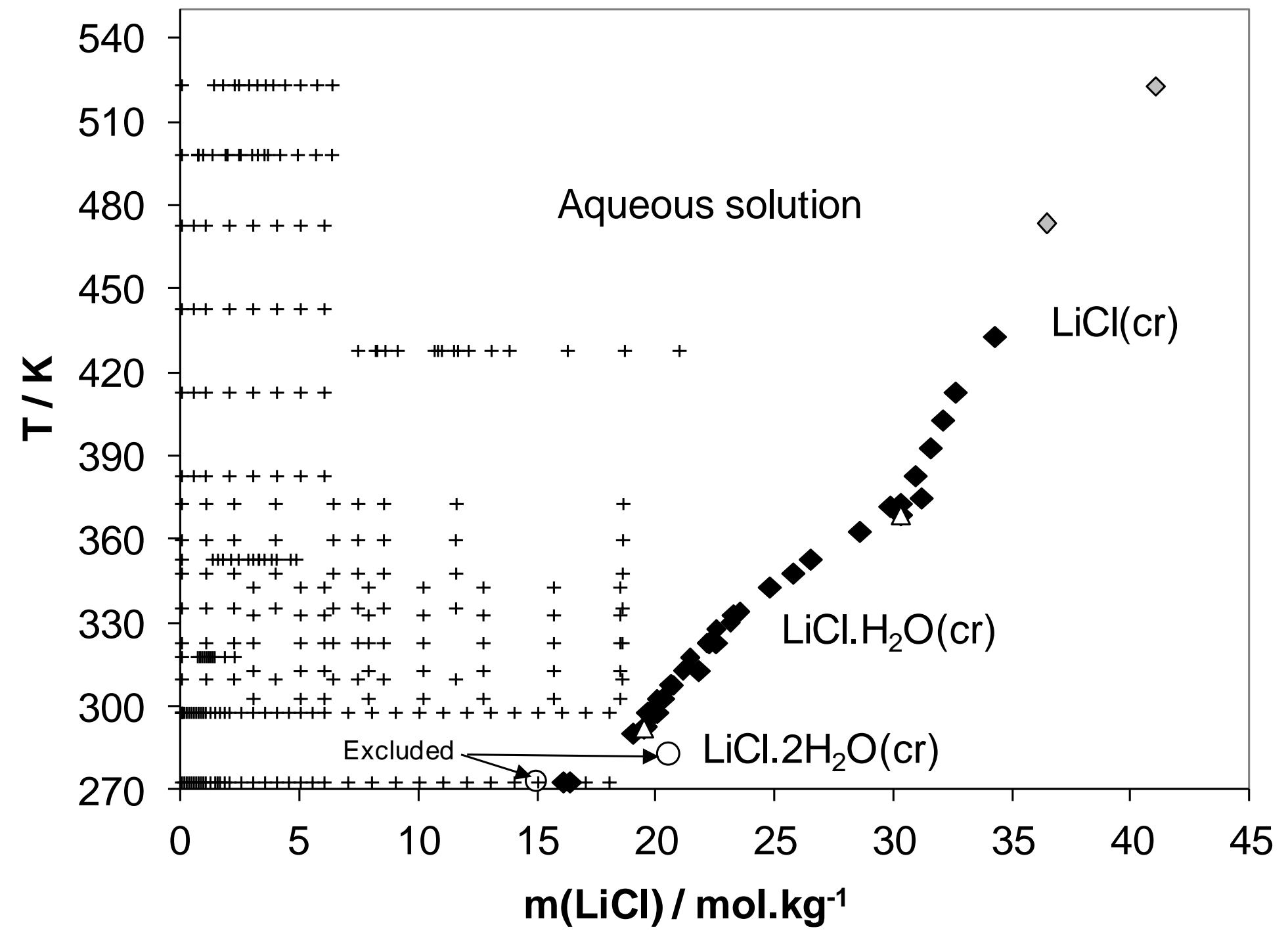

Figure 1 


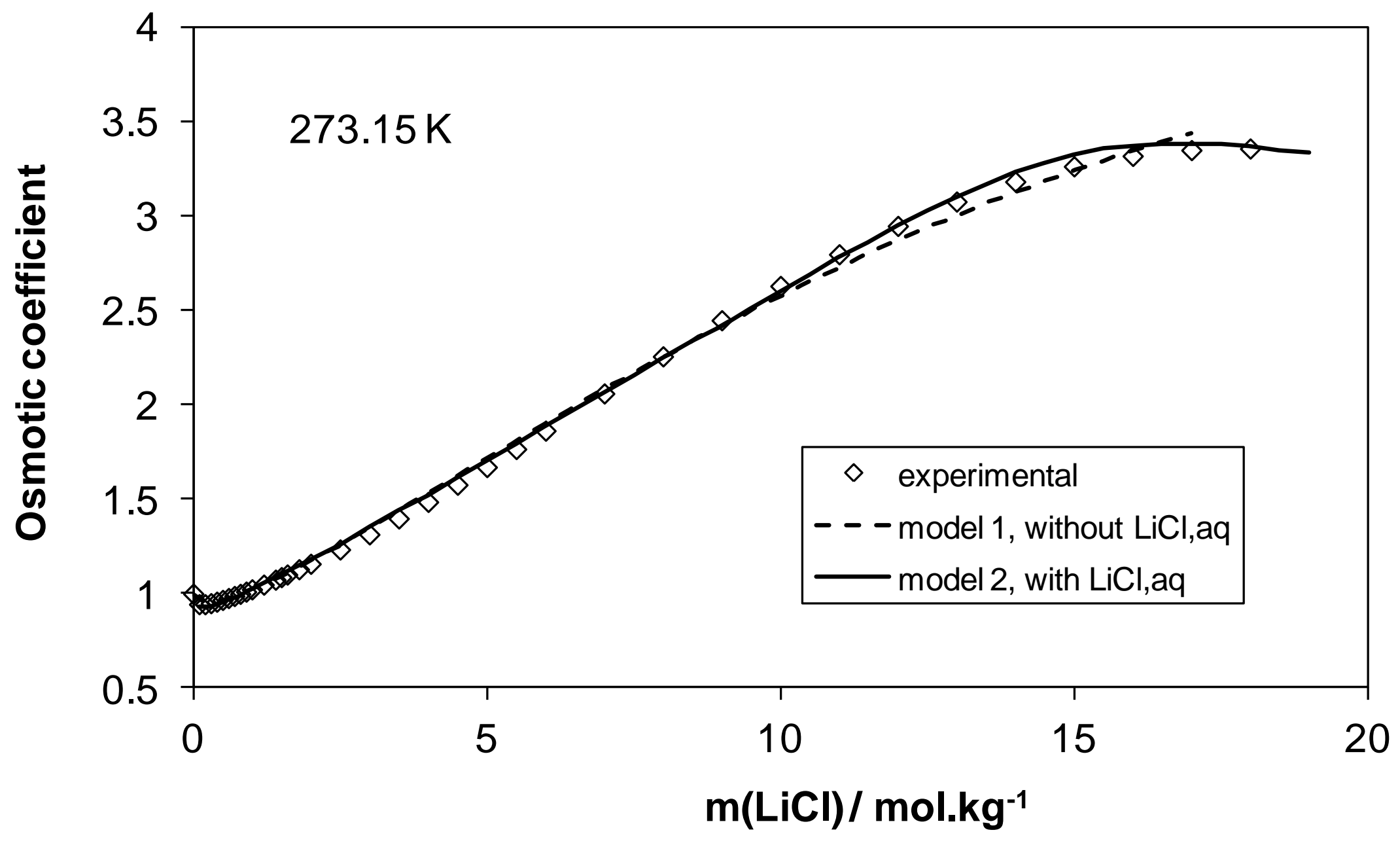

Figure $2 \mathrm{~A}$ 


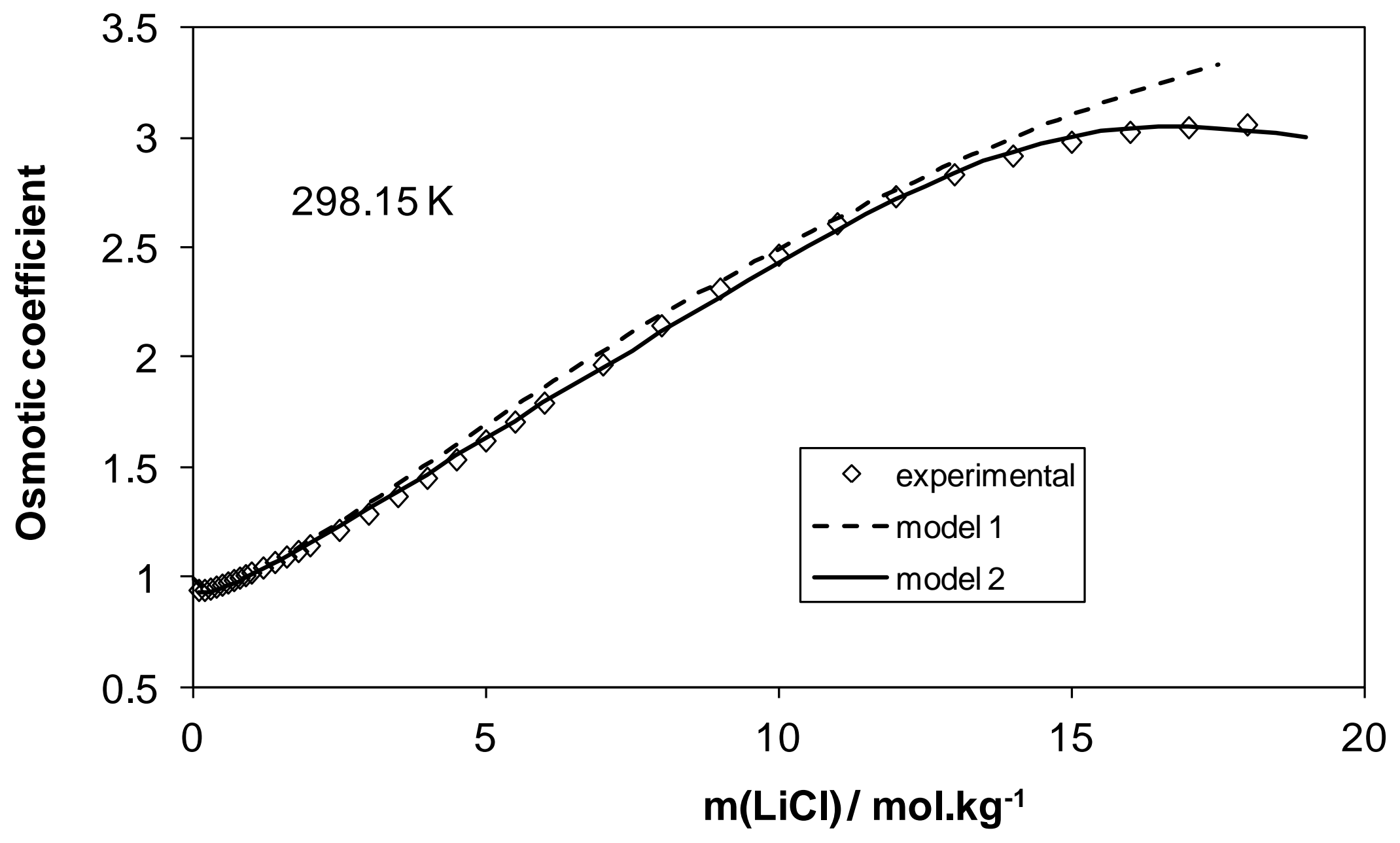

Figure 2 B 


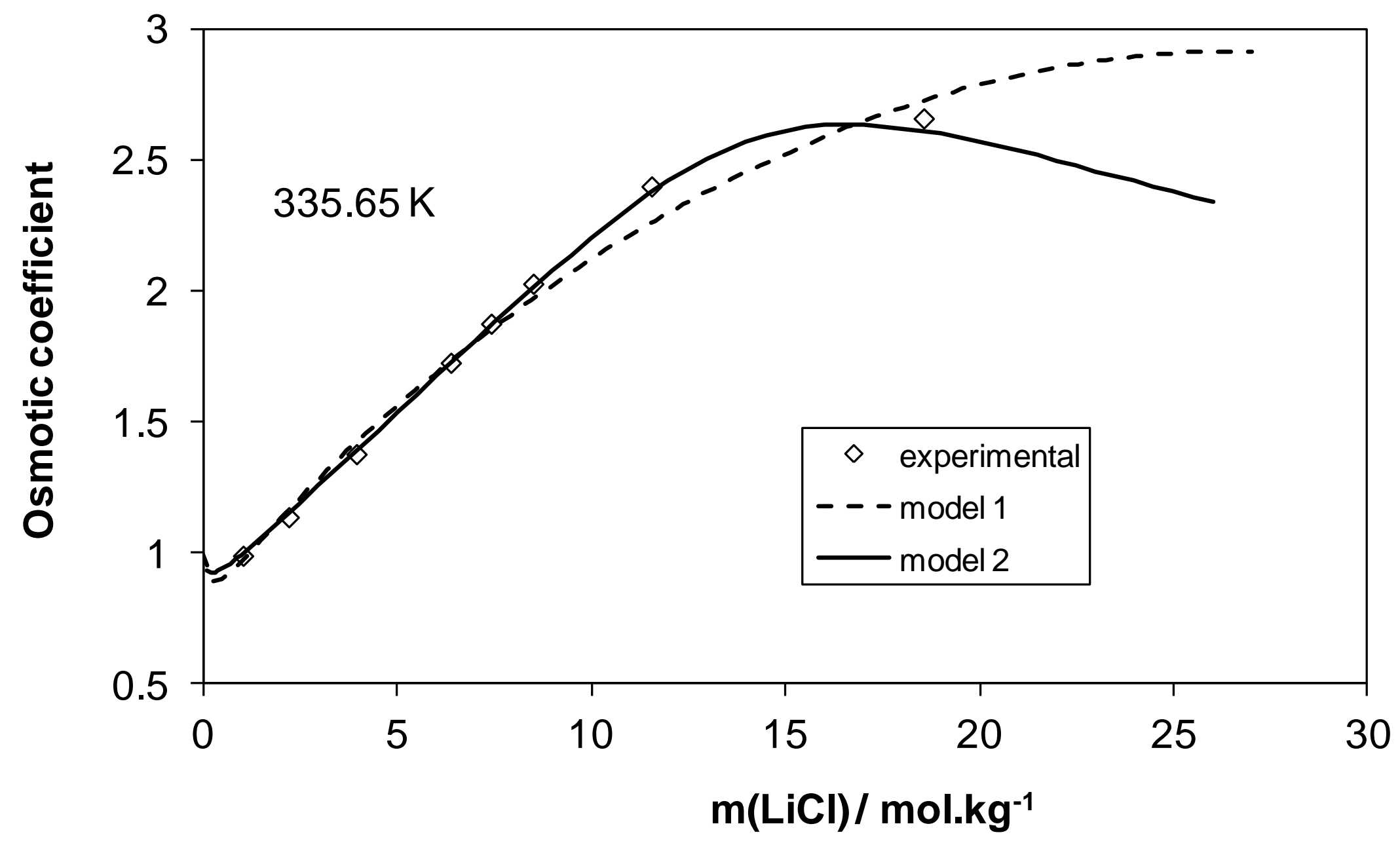

Figure $2 \mathrm{C}$ 


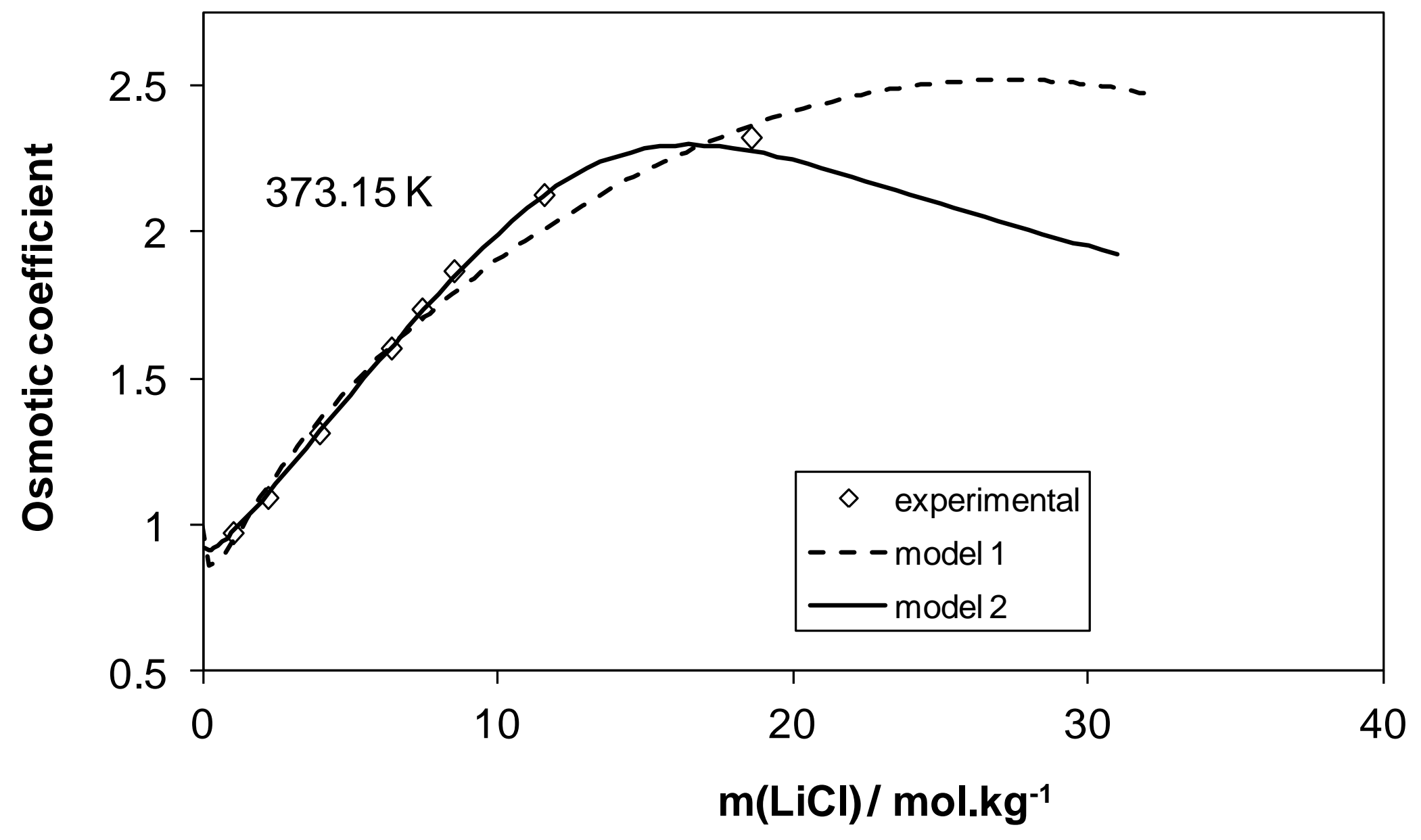

Figure 2 D 


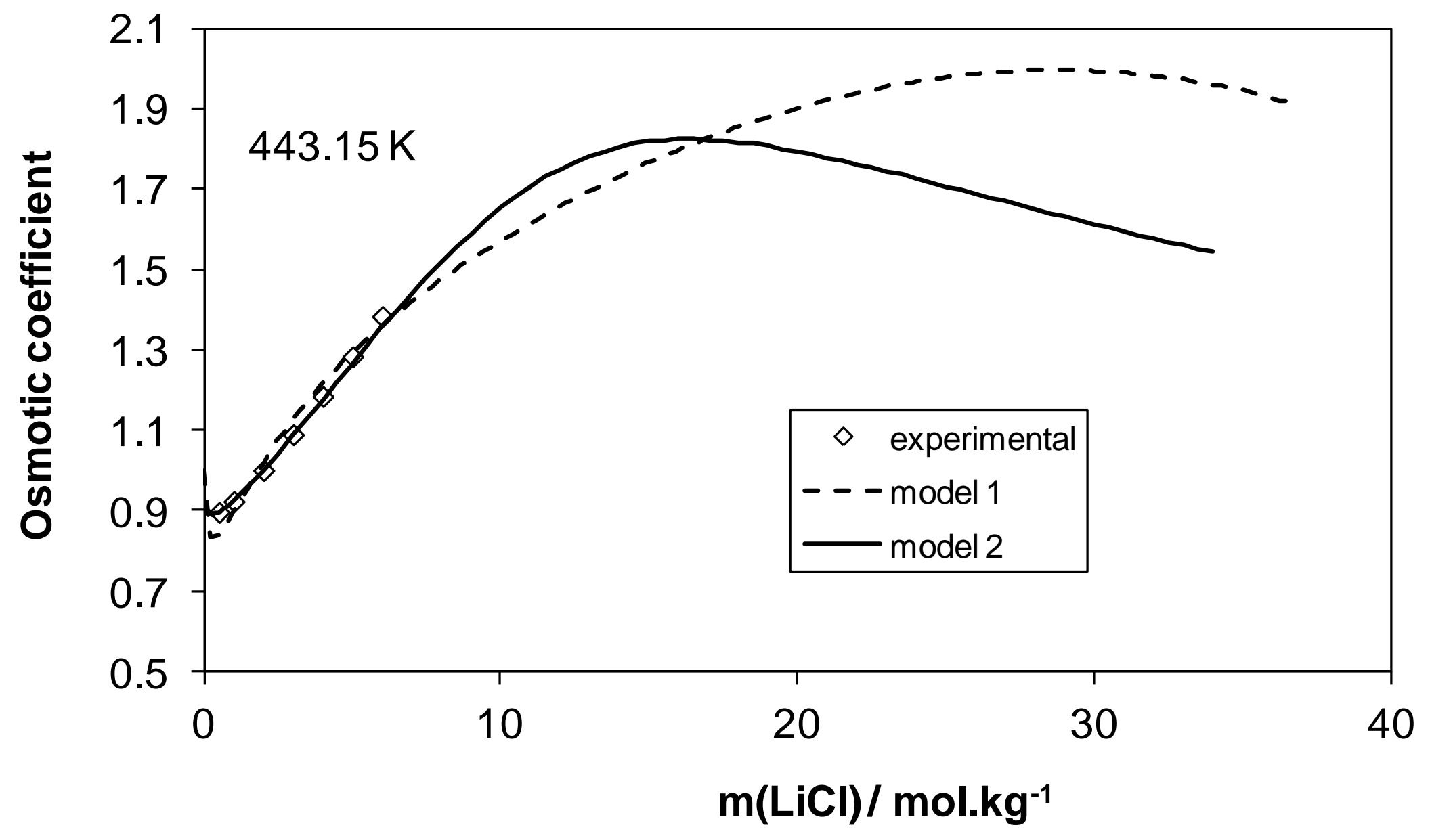

Figure $2 \mathrm{E}$ 


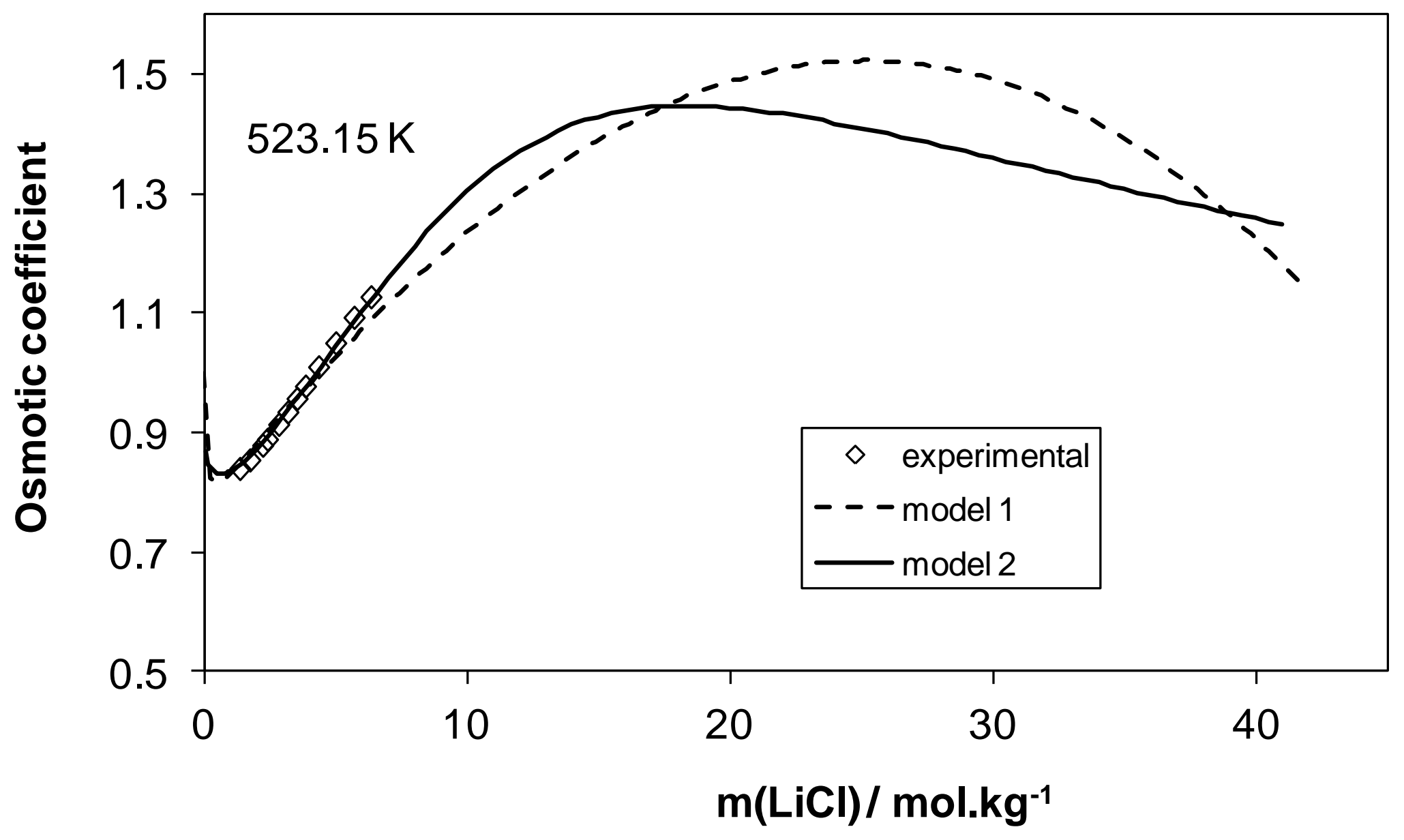

Figure $2 \mathrm{~F}$ 


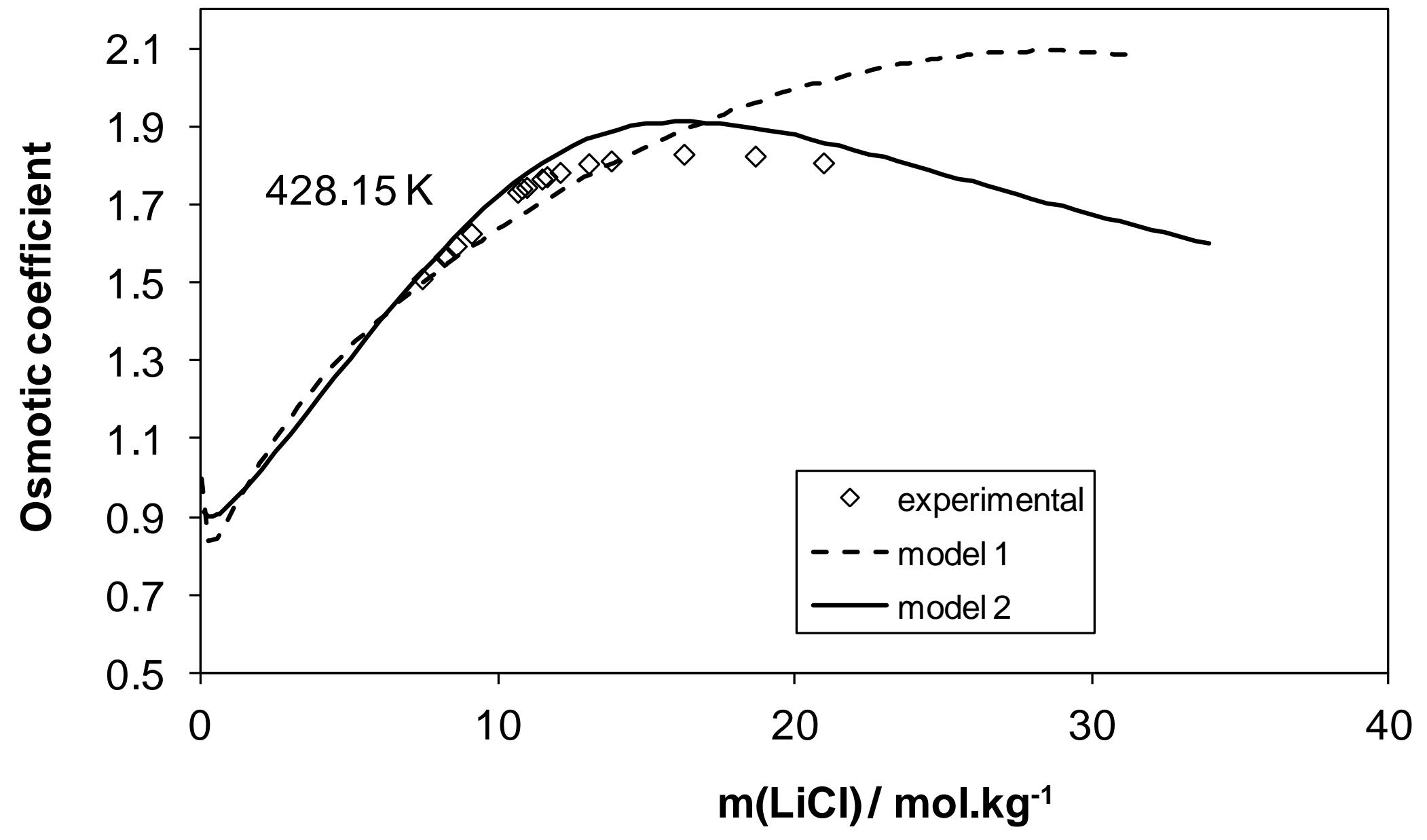

Figure 2 G 


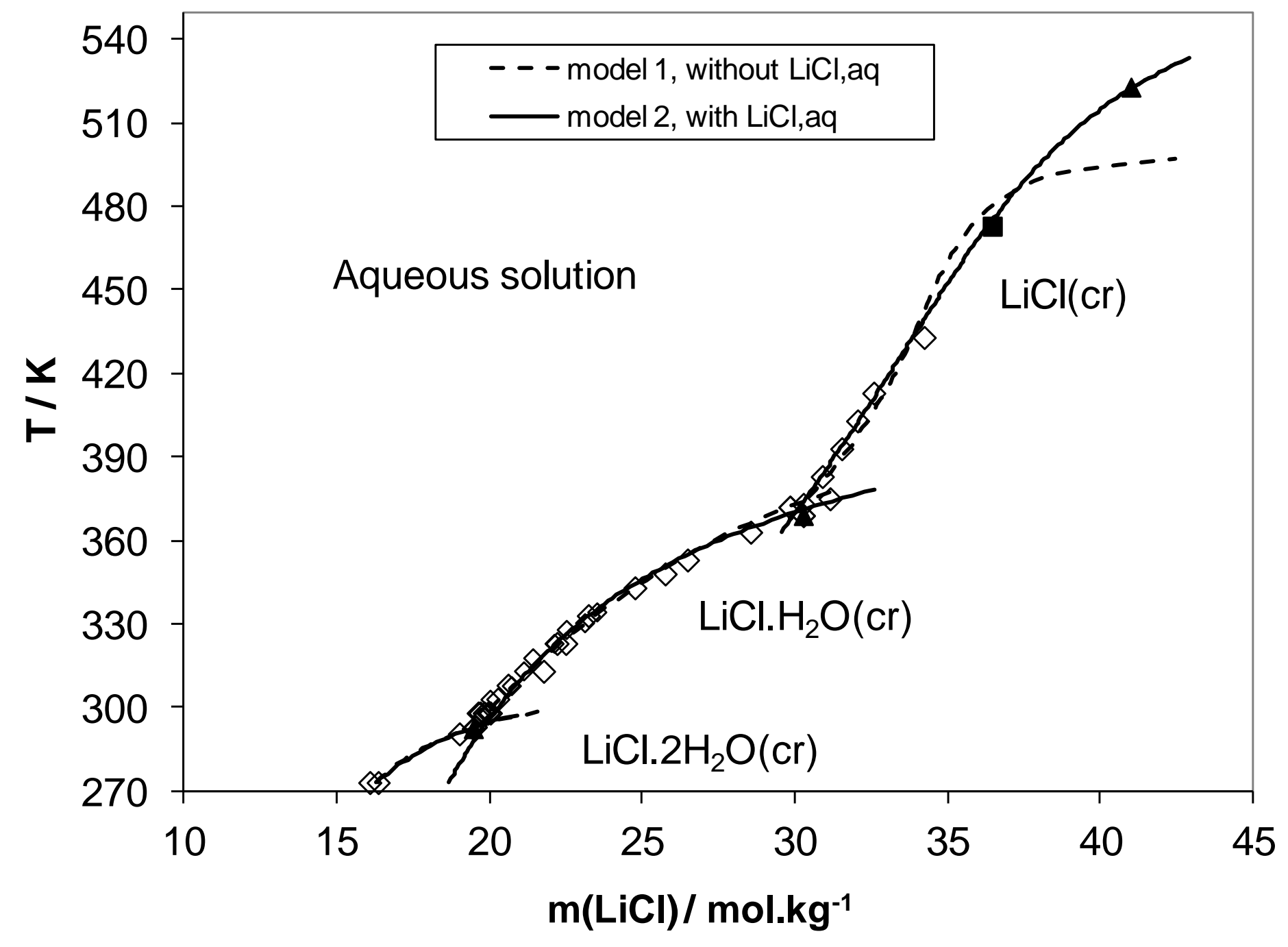

Figure 3 


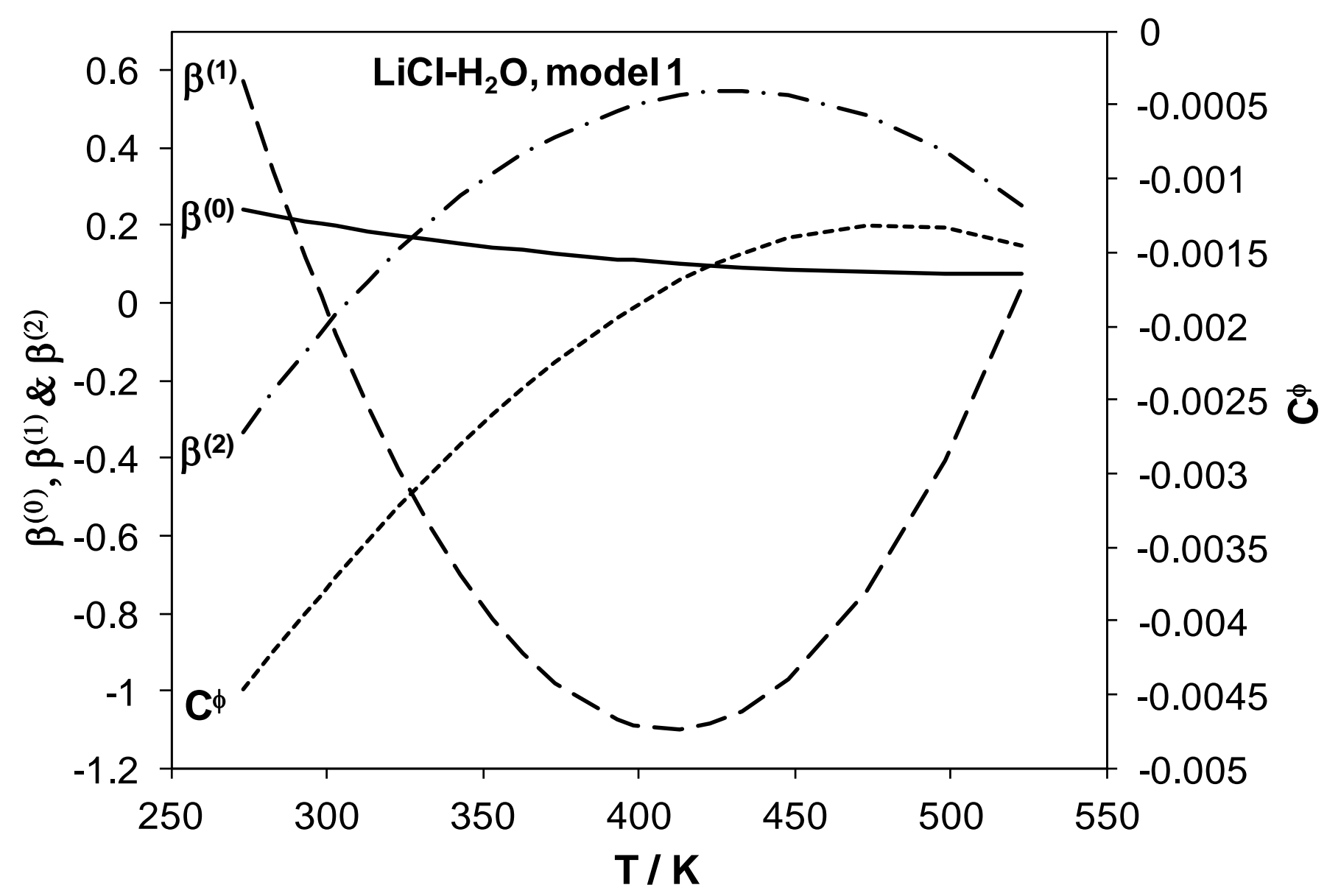

Figure 4 A 


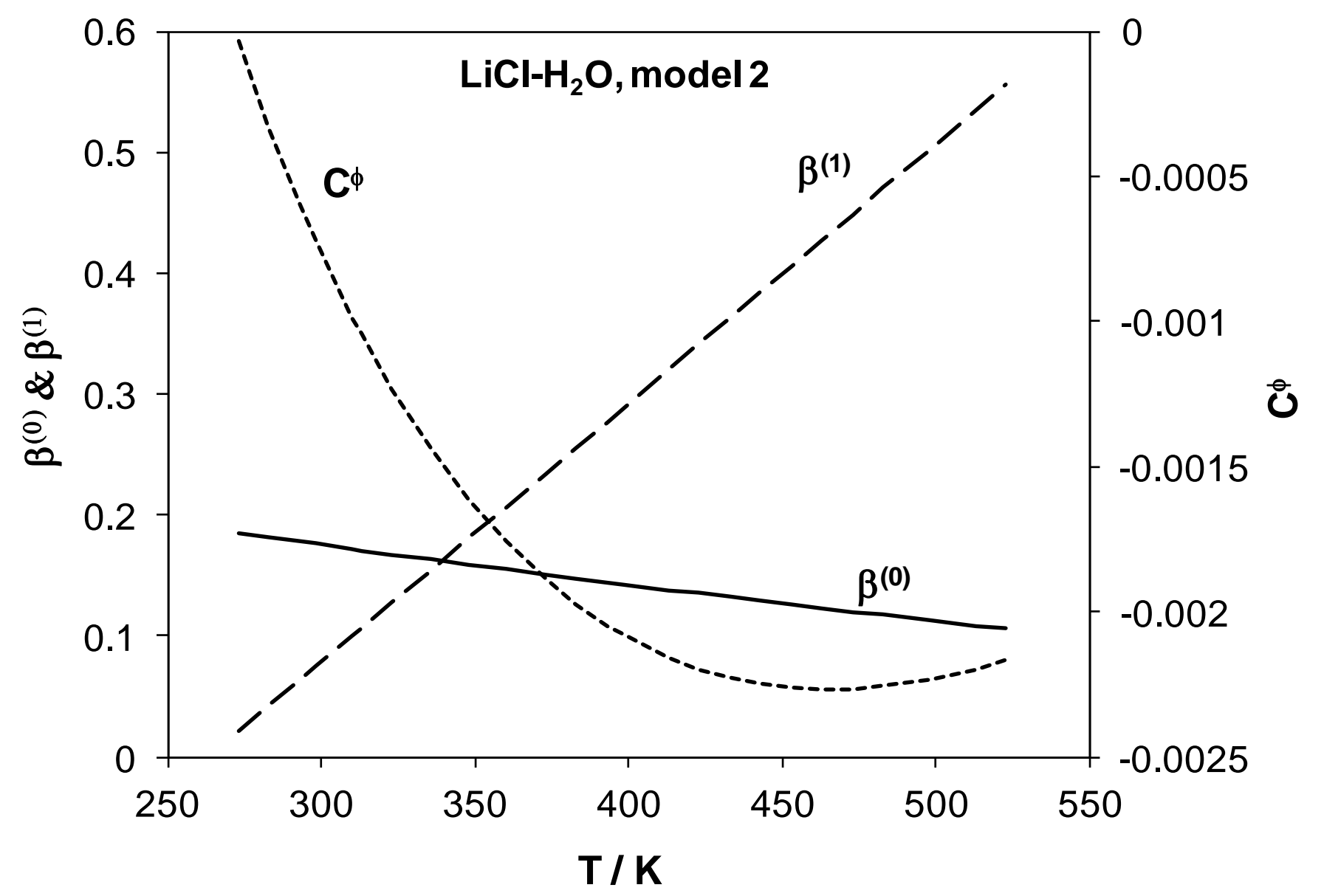

Figure 4 B 


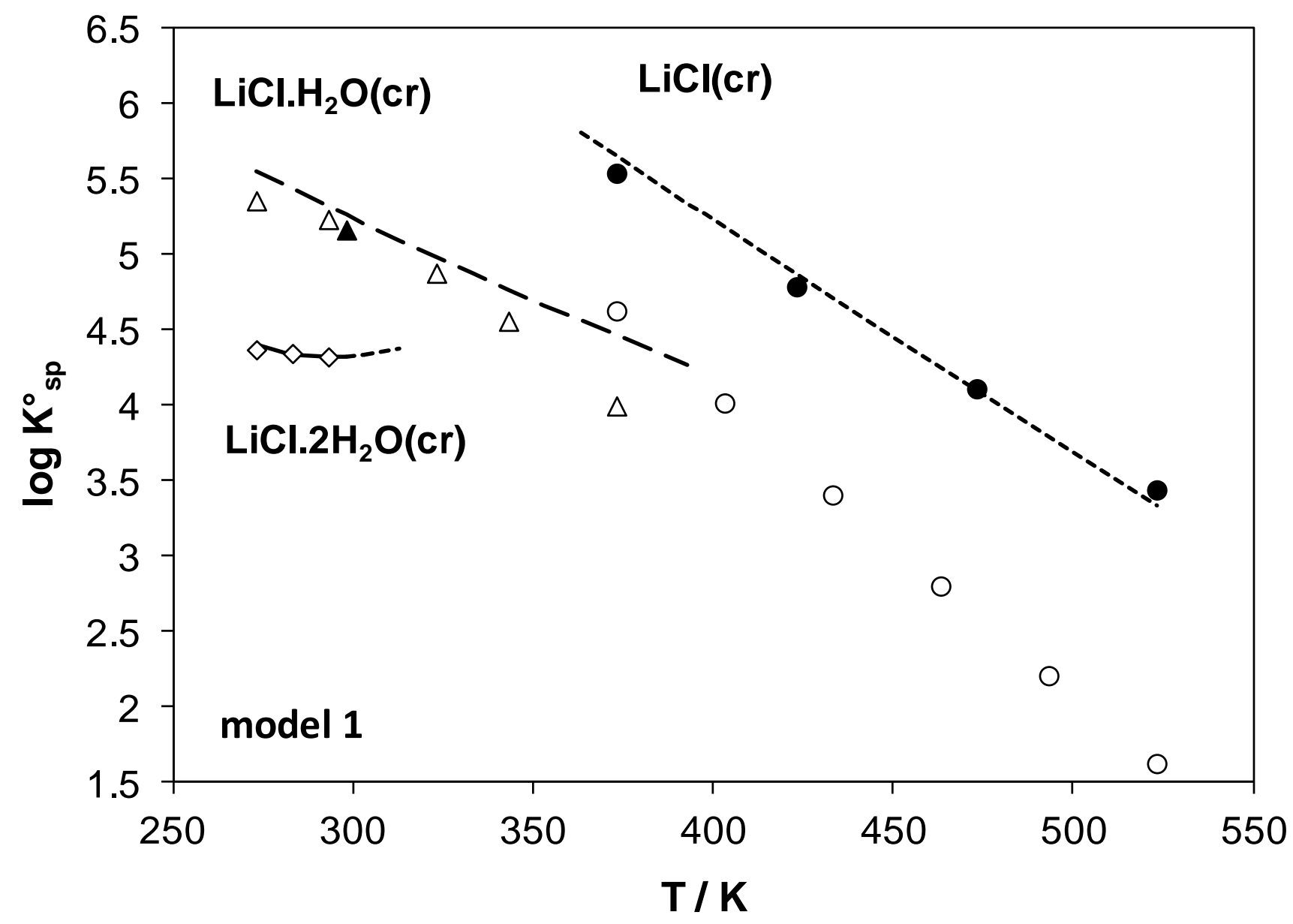

Figure $5 \mathrm{~A}$ 


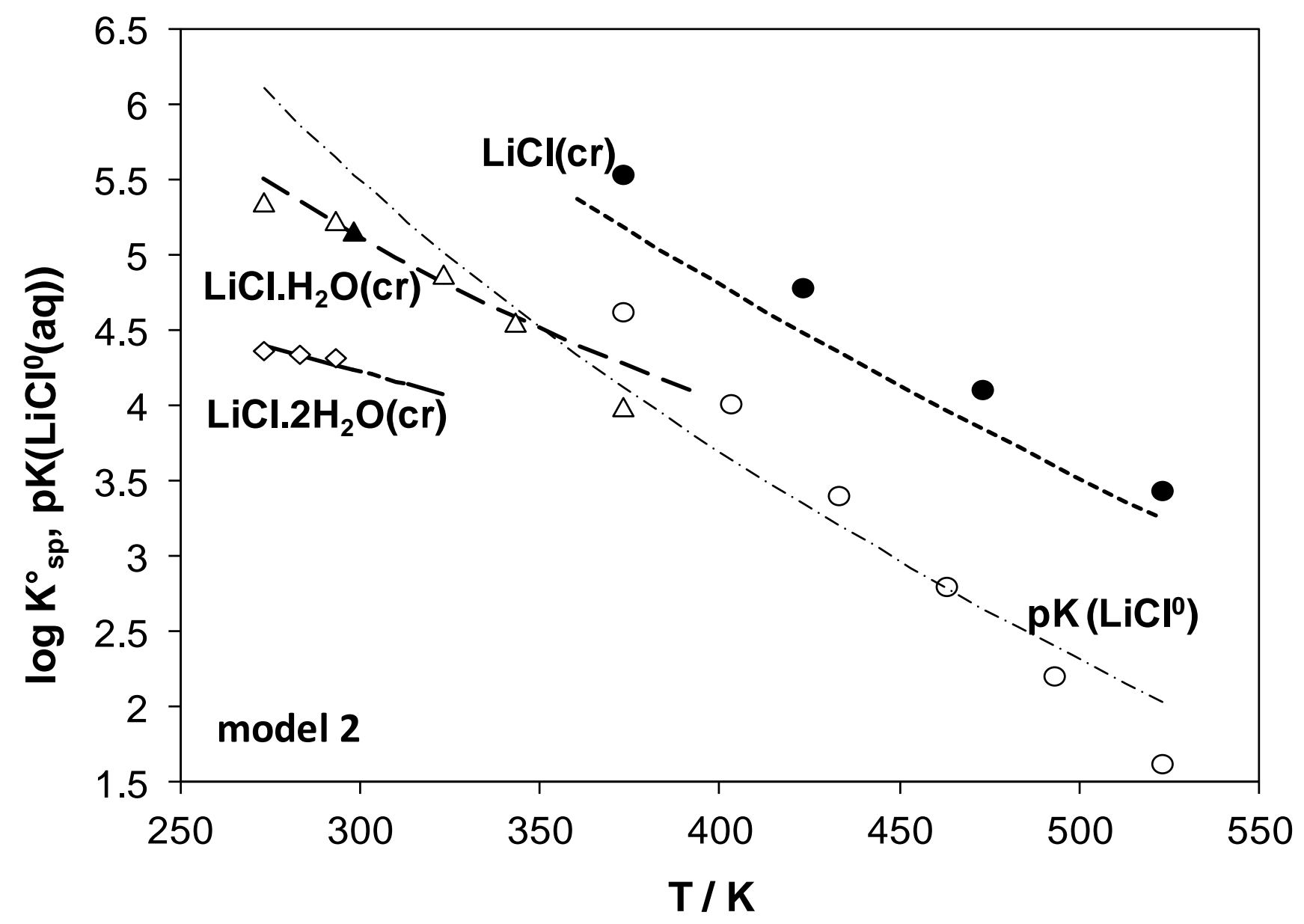

Figure 5 B 


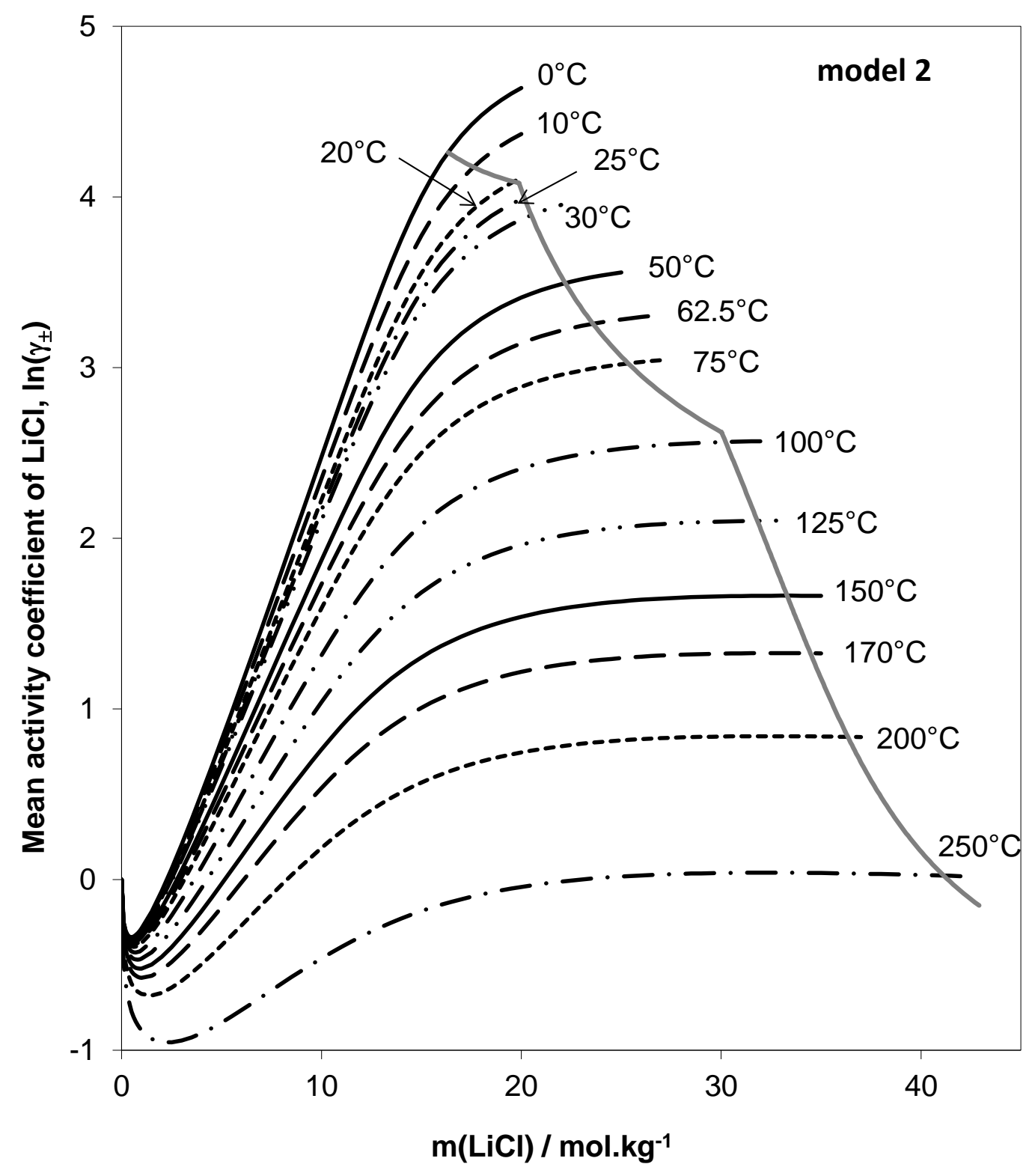

Figure 6 


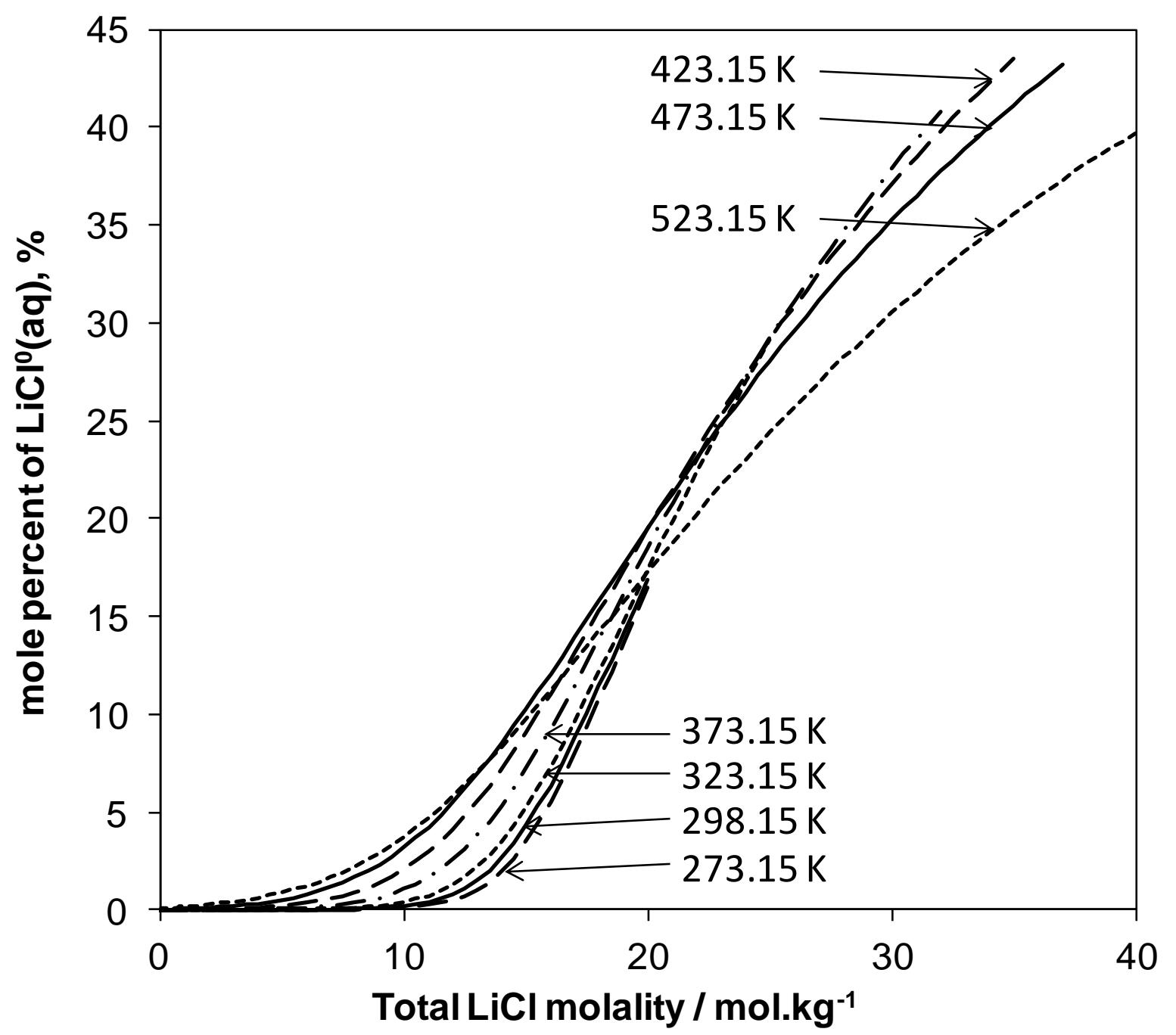

Figure 7 


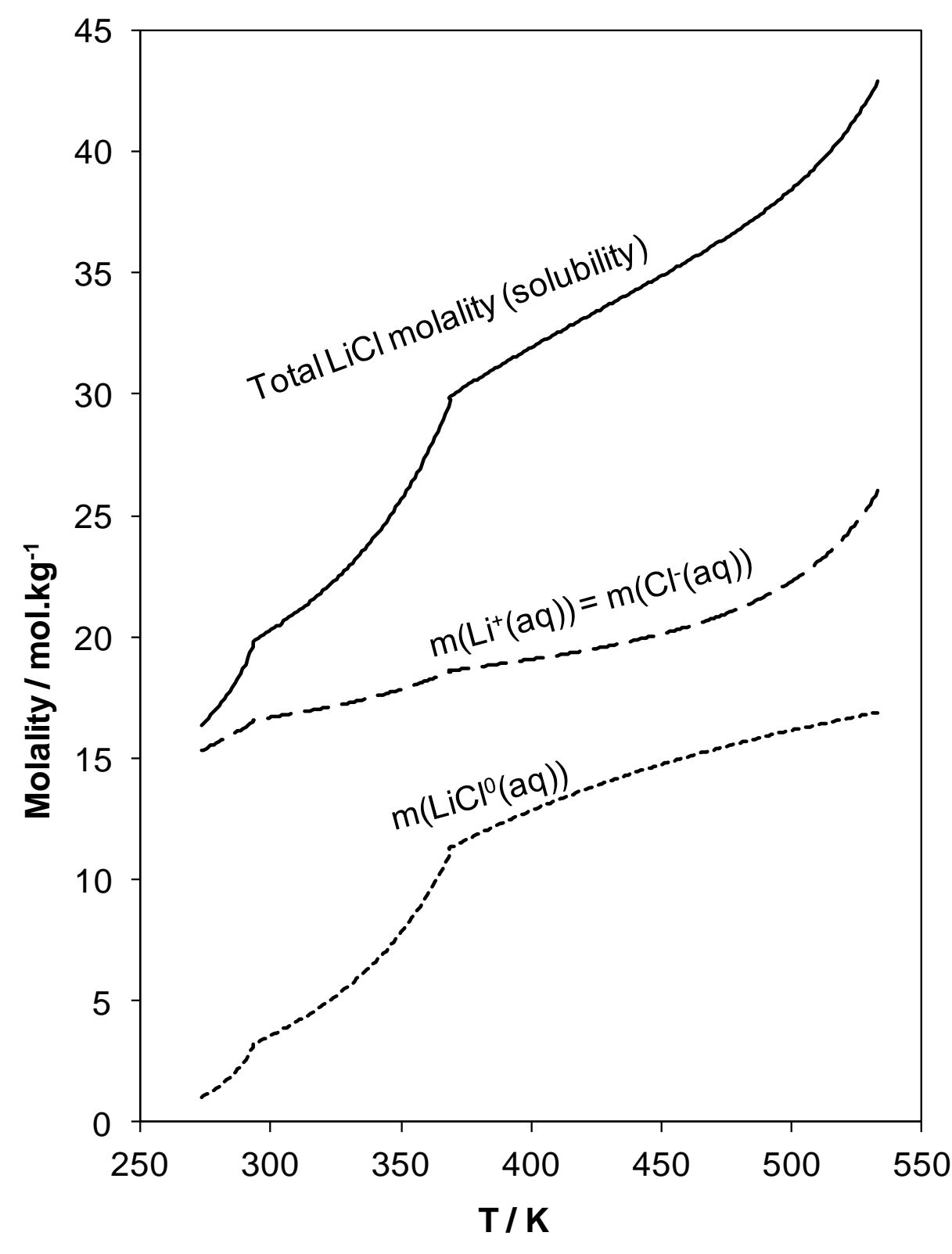

Figure 8 


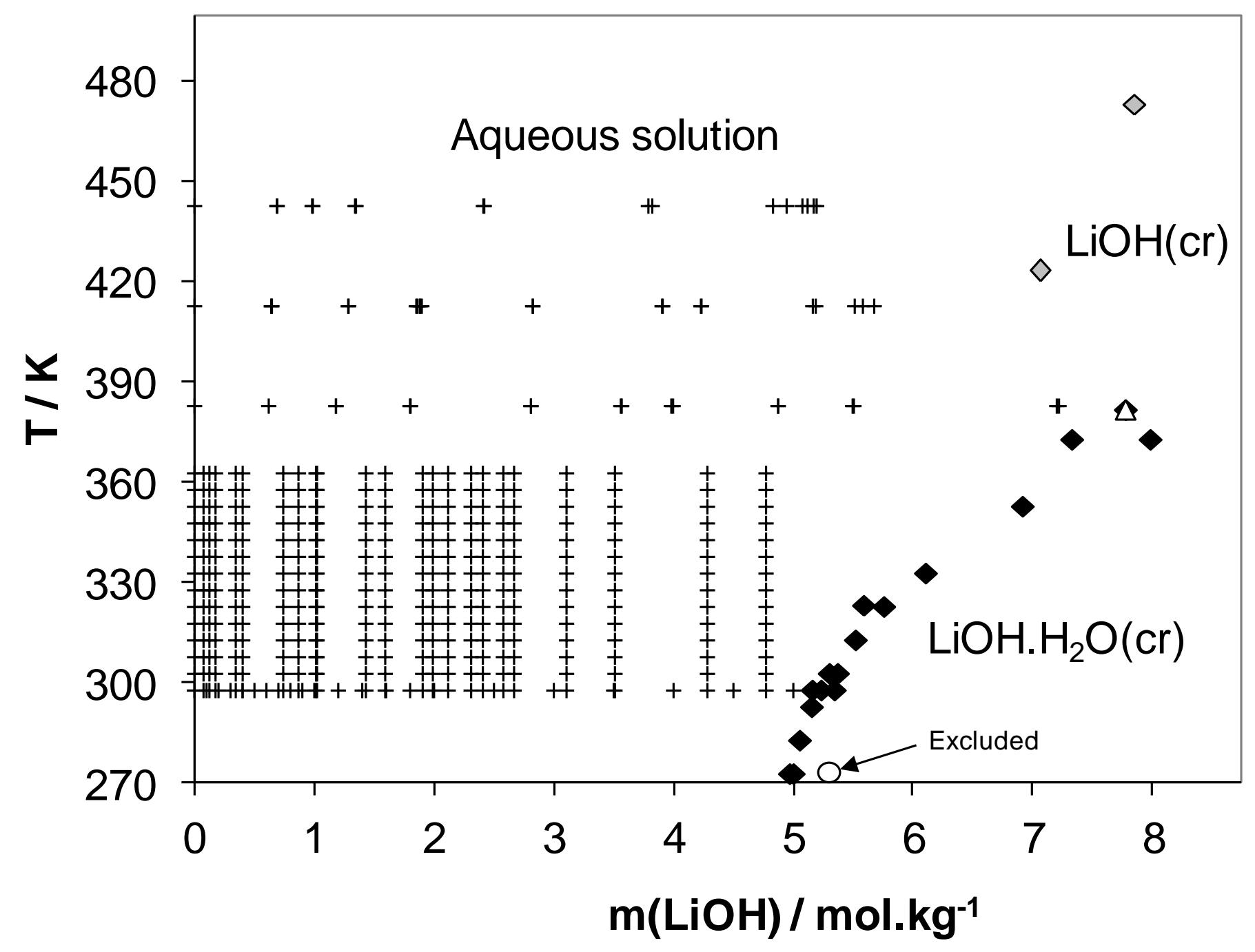

Figure 9 


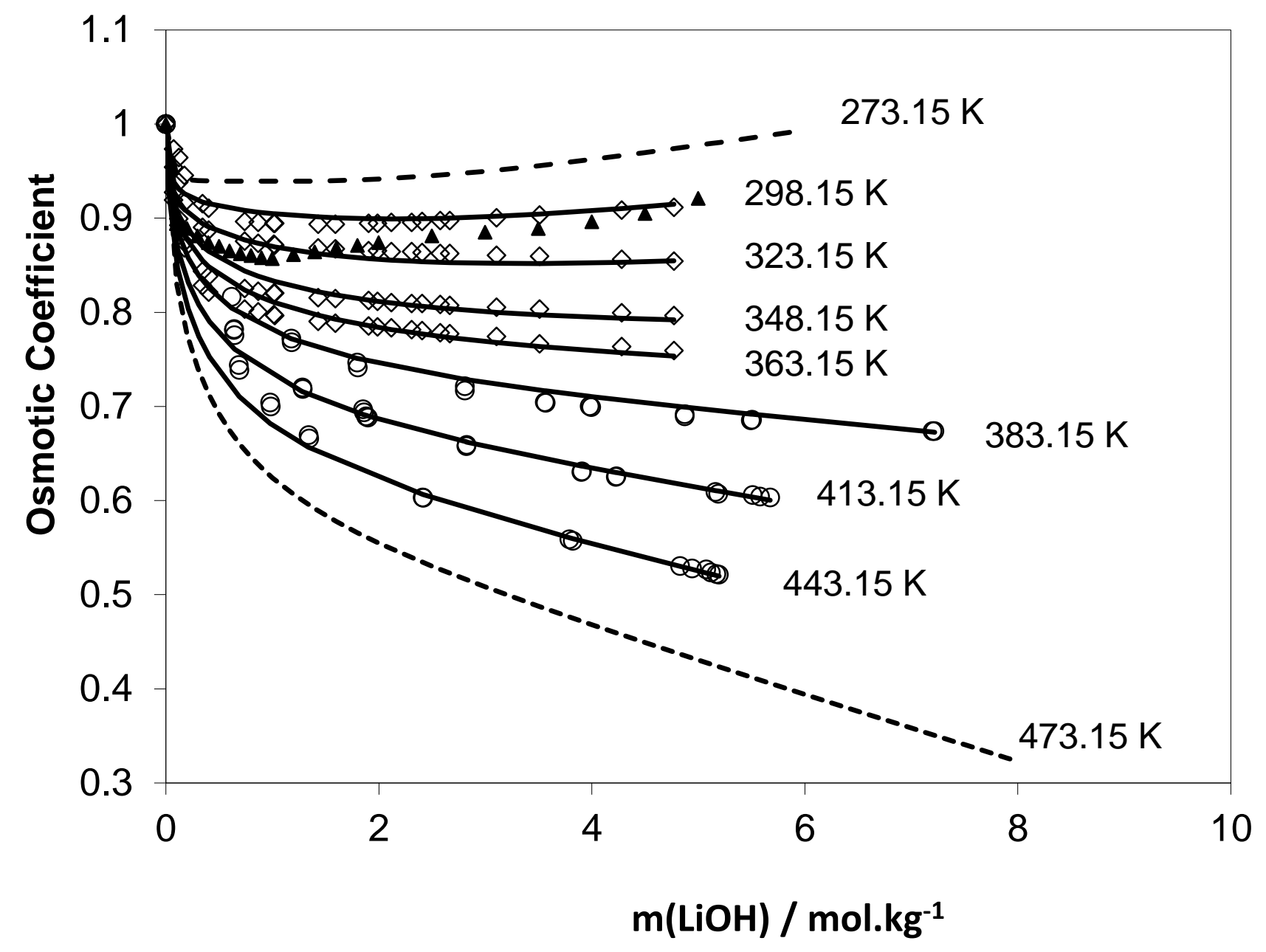

Figure 10 


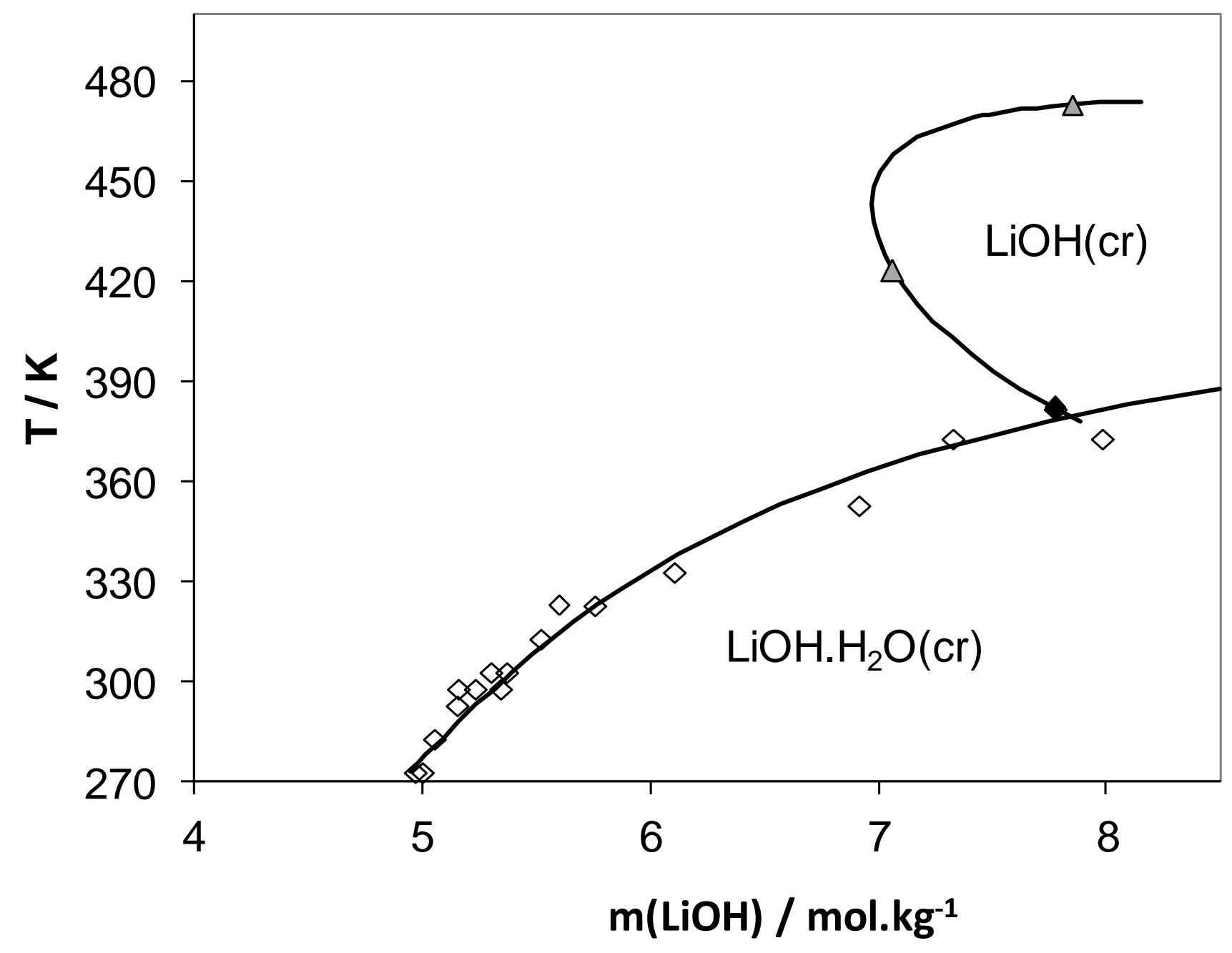

Figure 11 


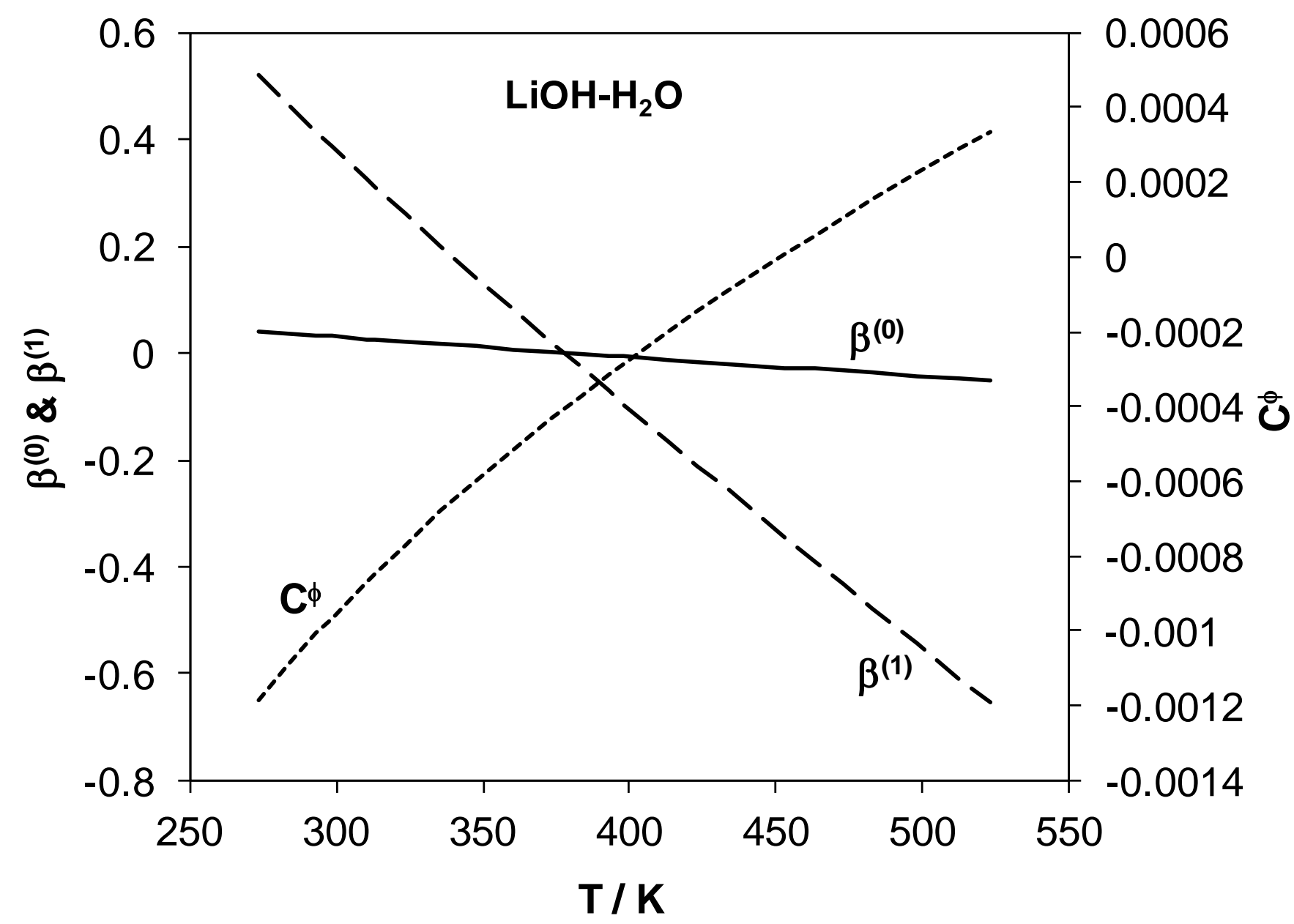

Figure 12 


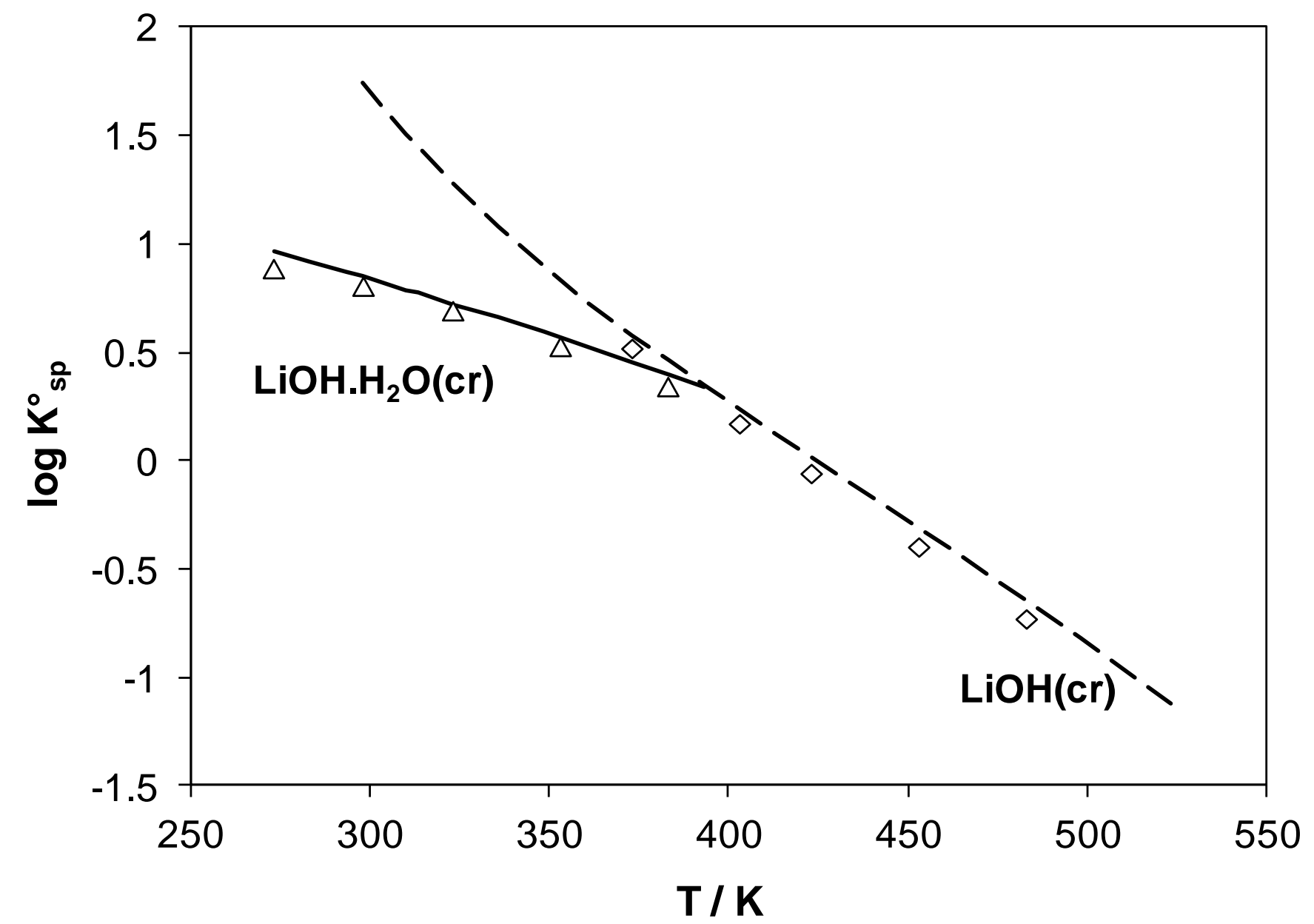

Figure 13 


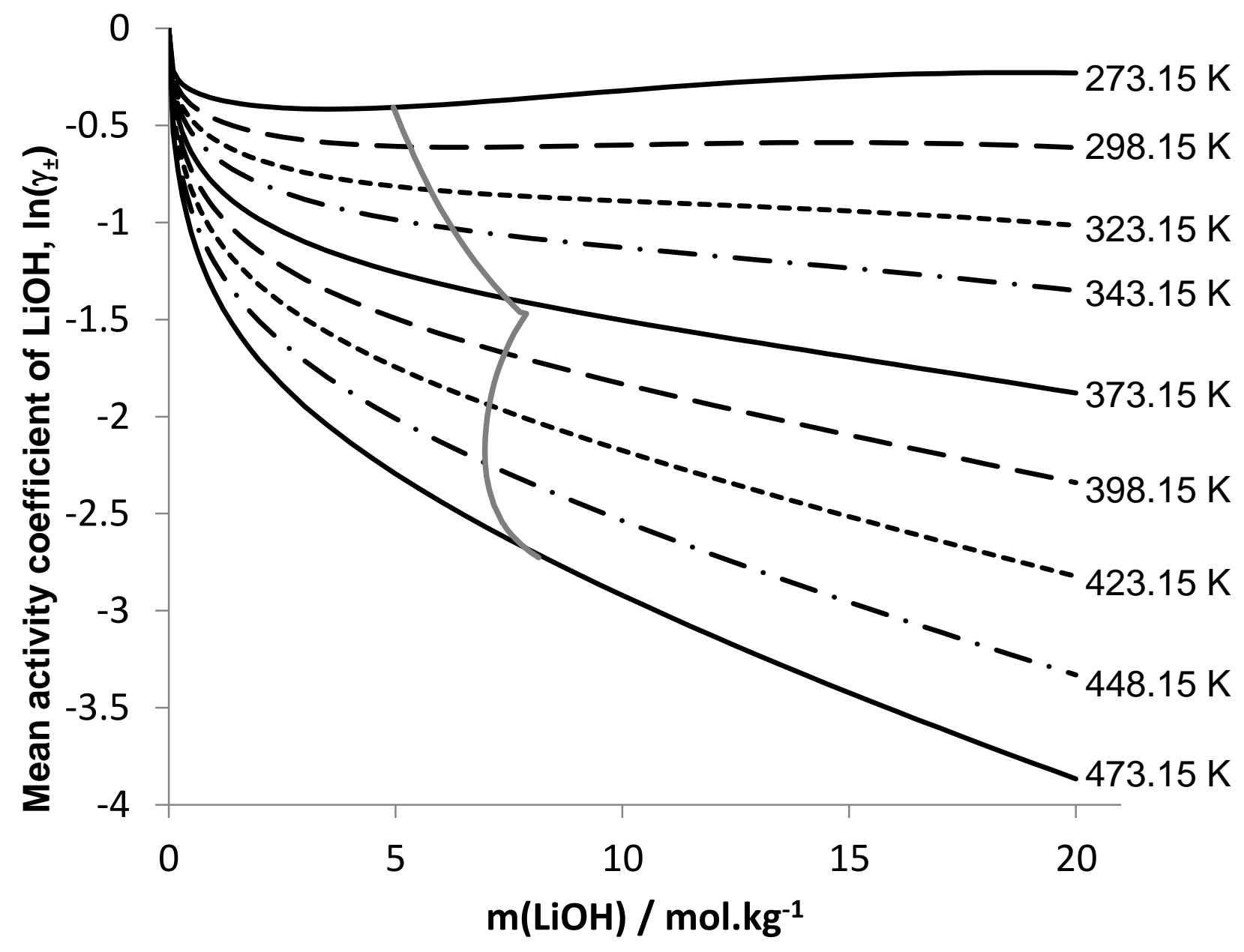

Figure 14 


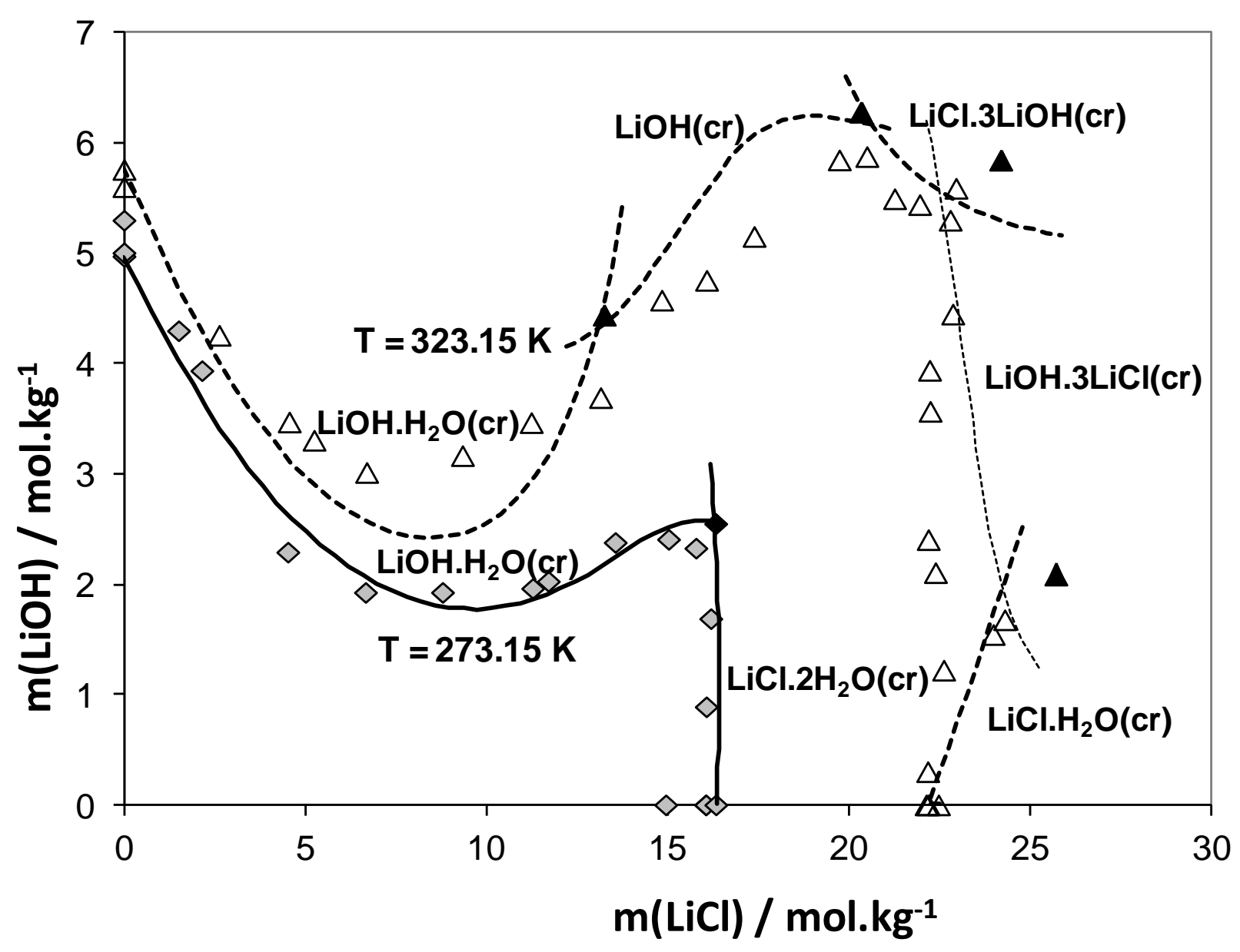

Figure $15 \mathrm{~A}$ 


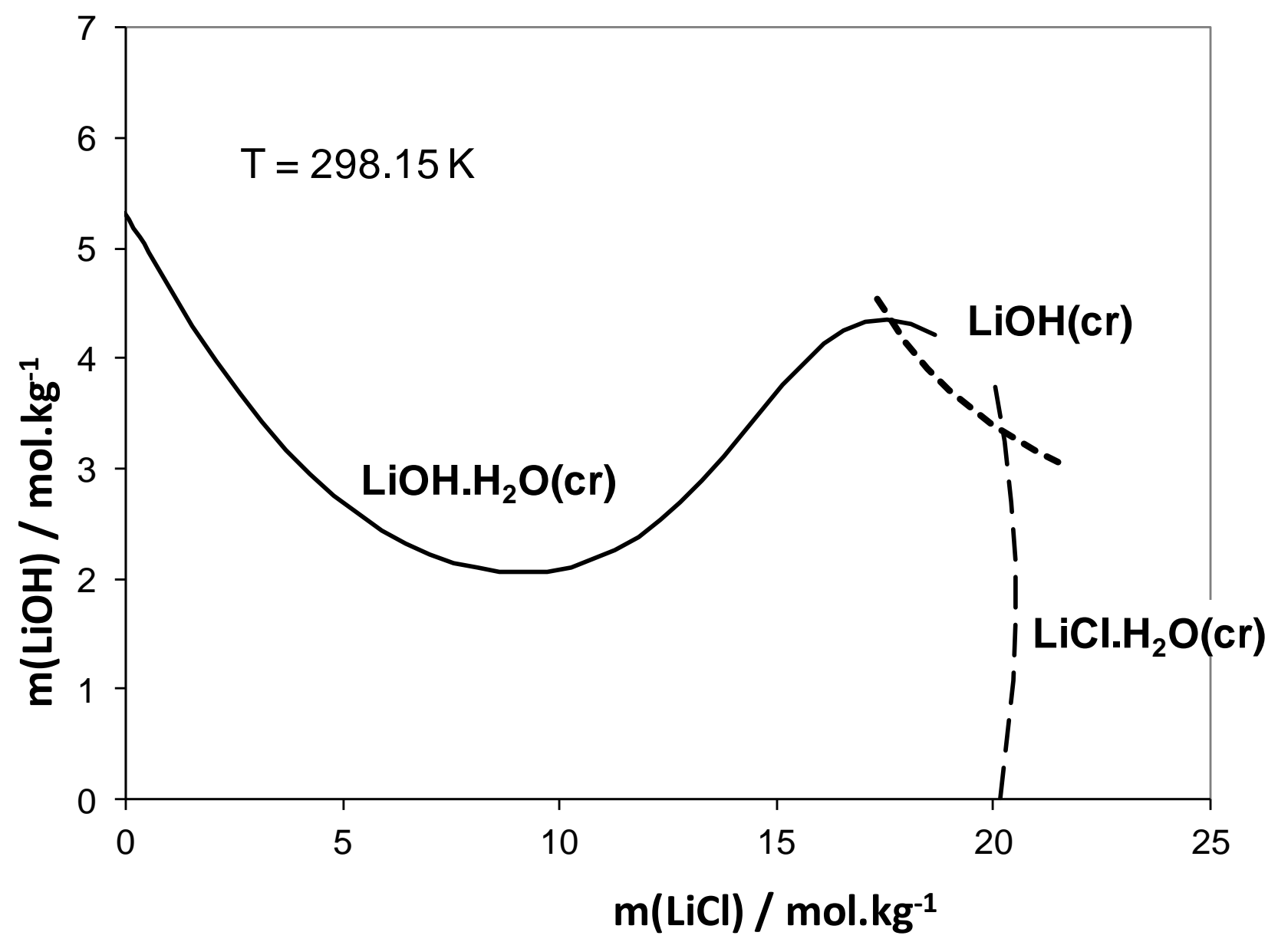

Figure 15 B 


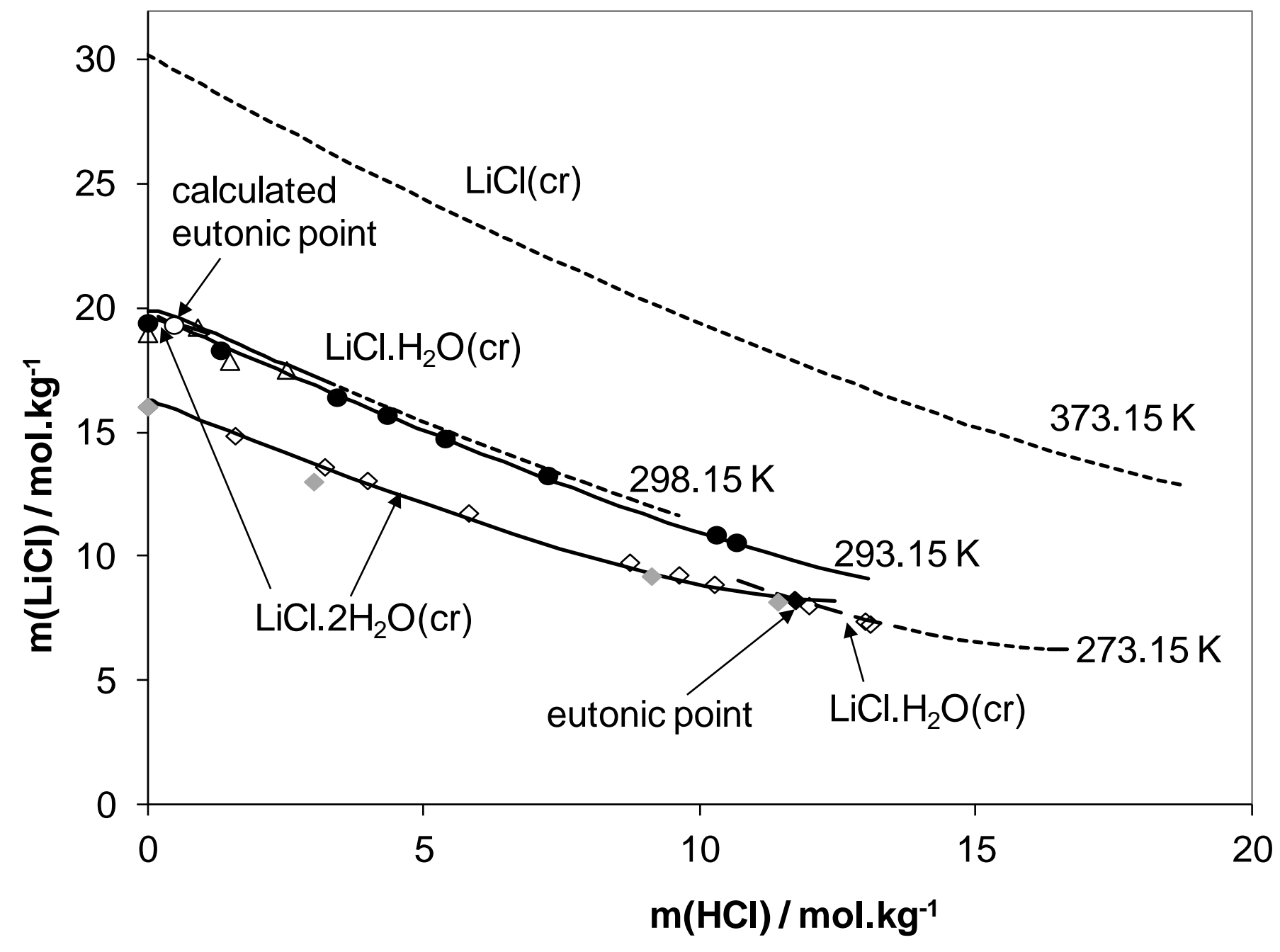

Figure 16 


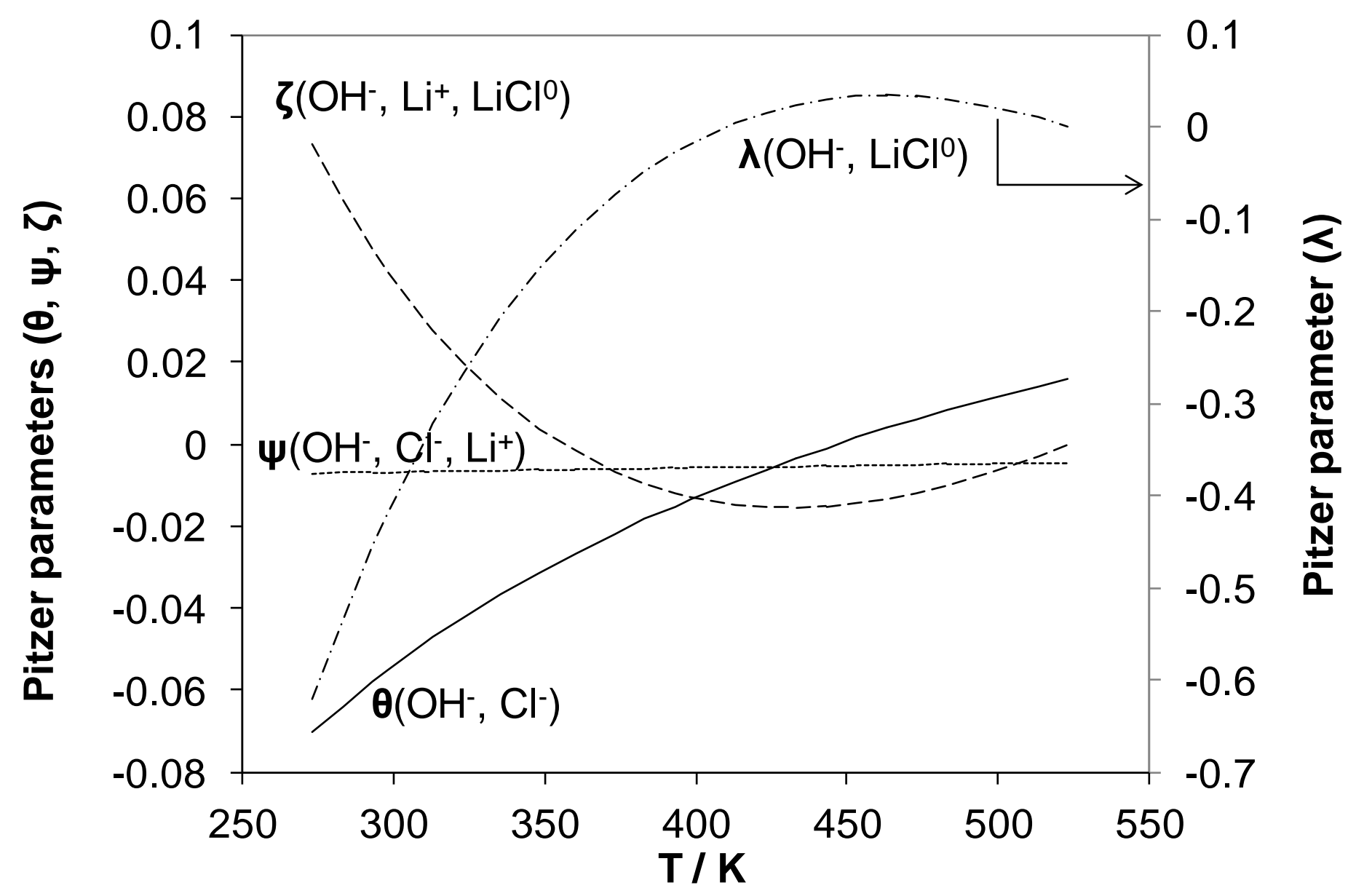

Figure 17 


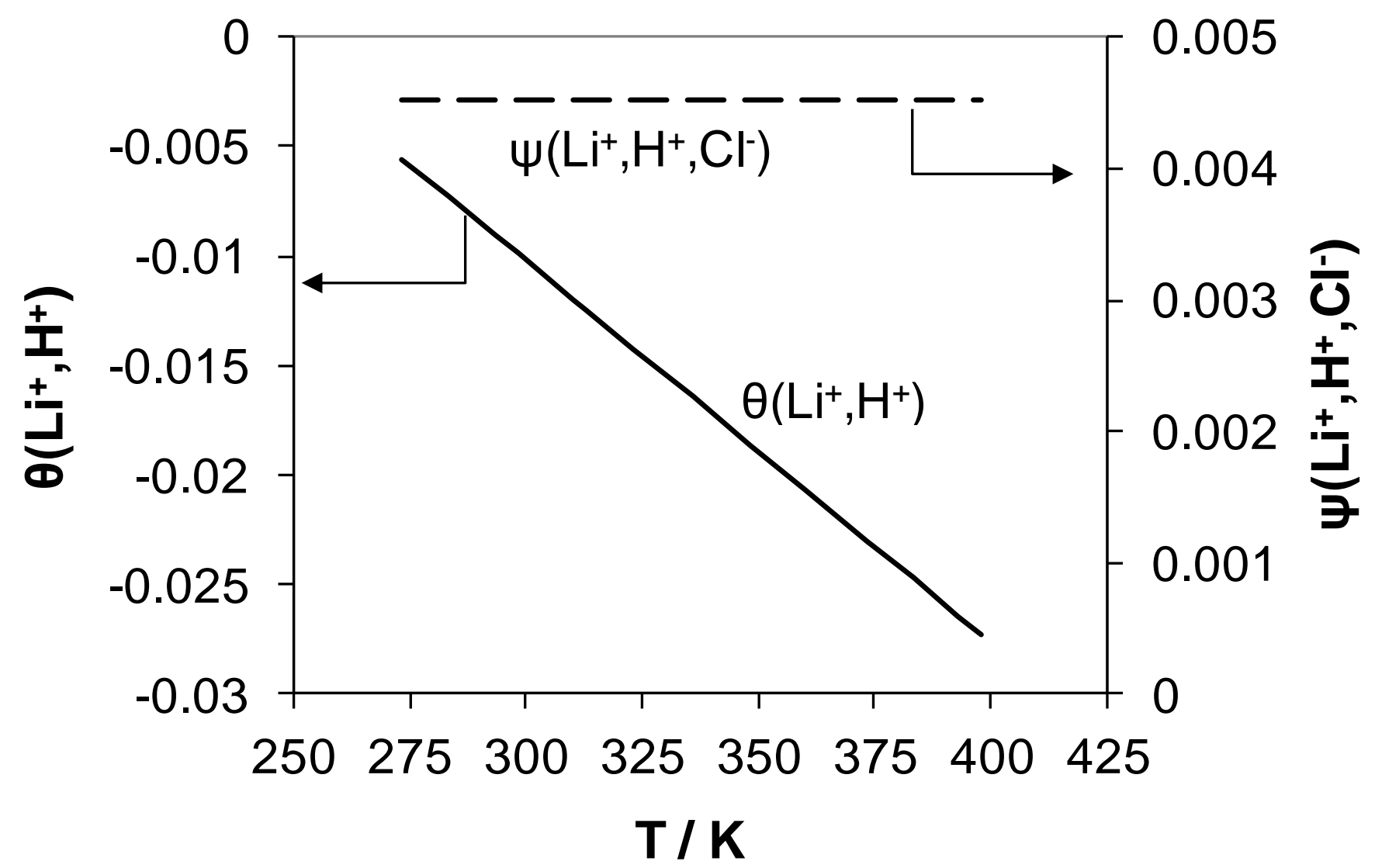

Figure 18 


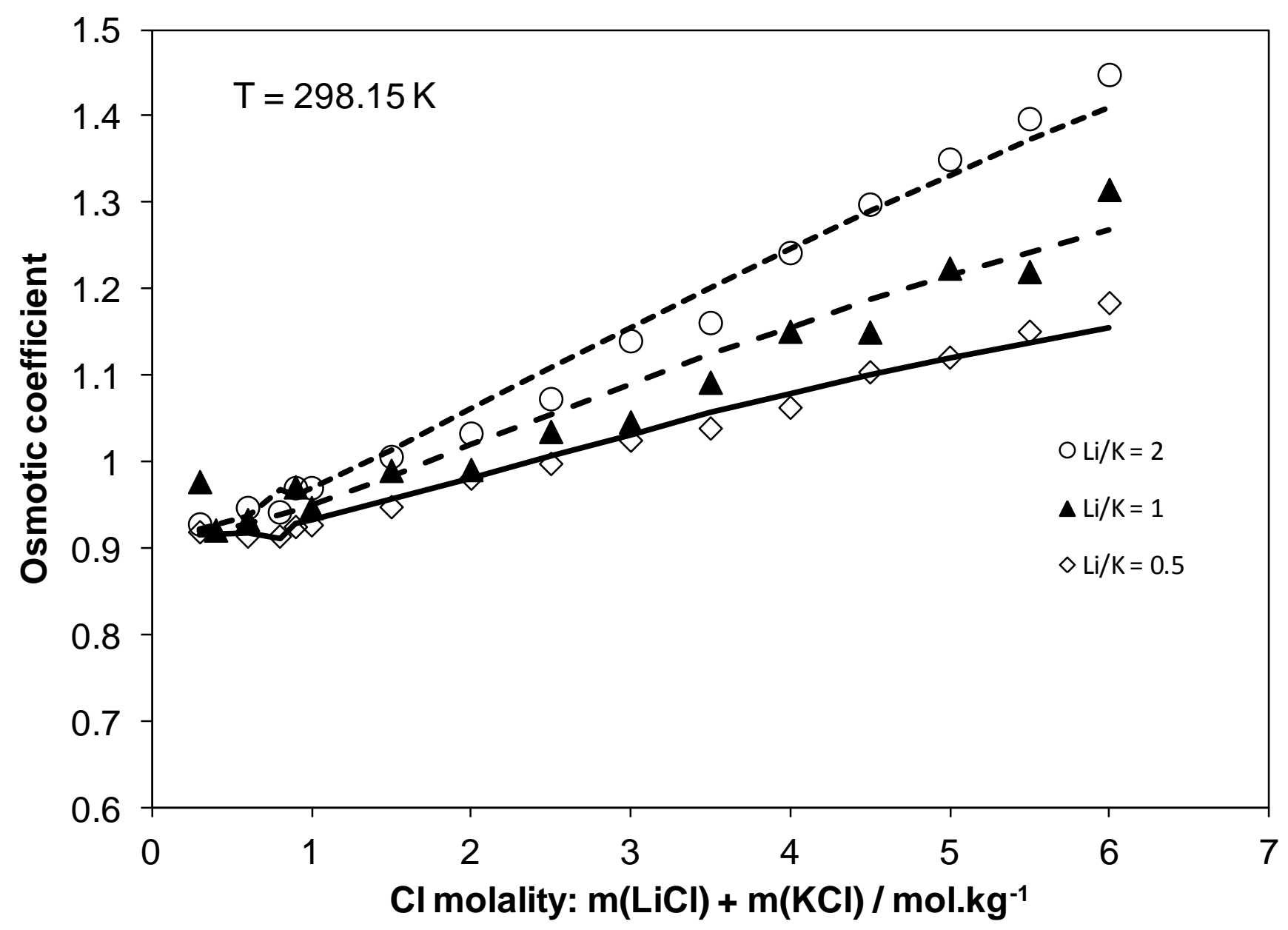

Figure 19 


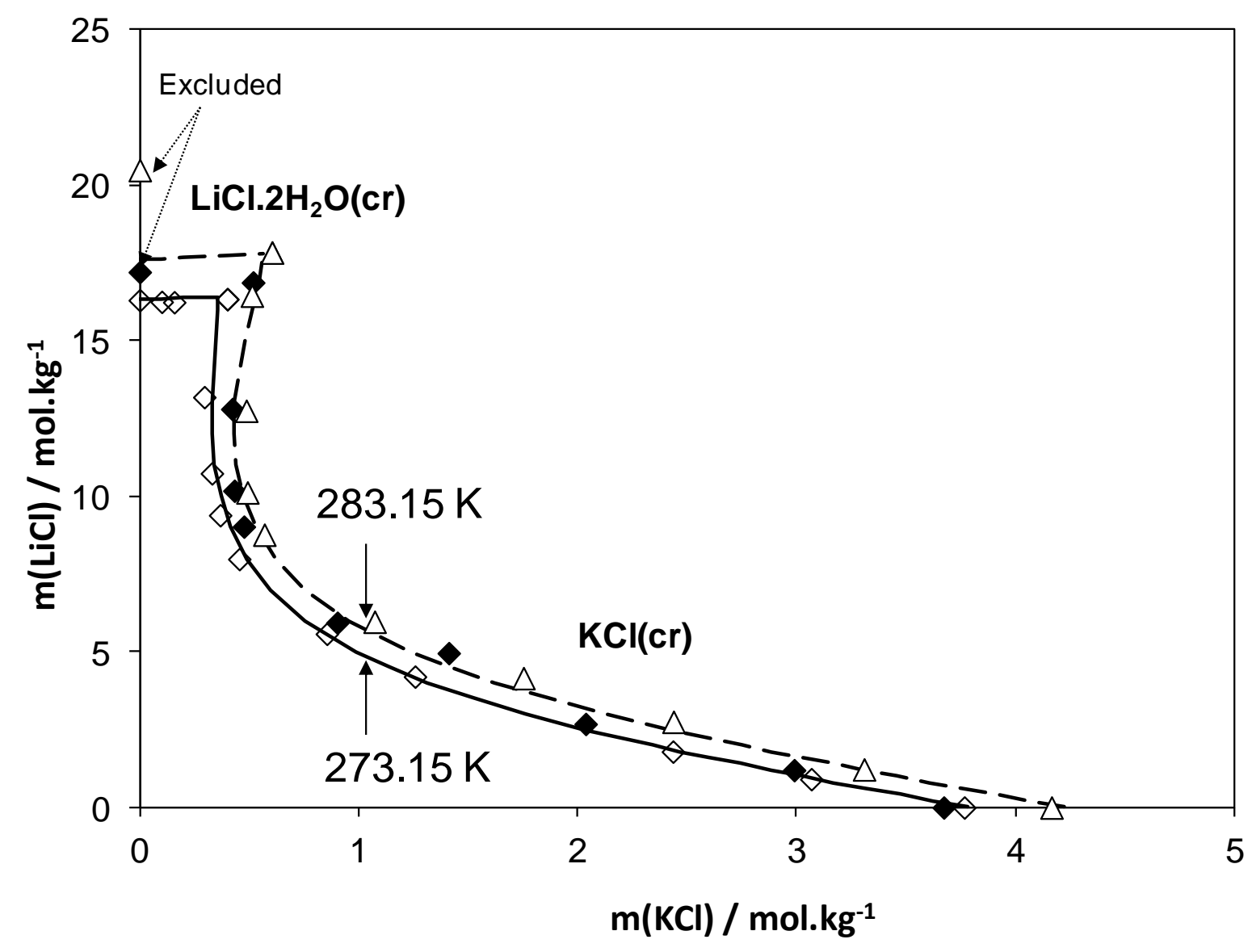

Figure $20 \mathrm{~A}$ 


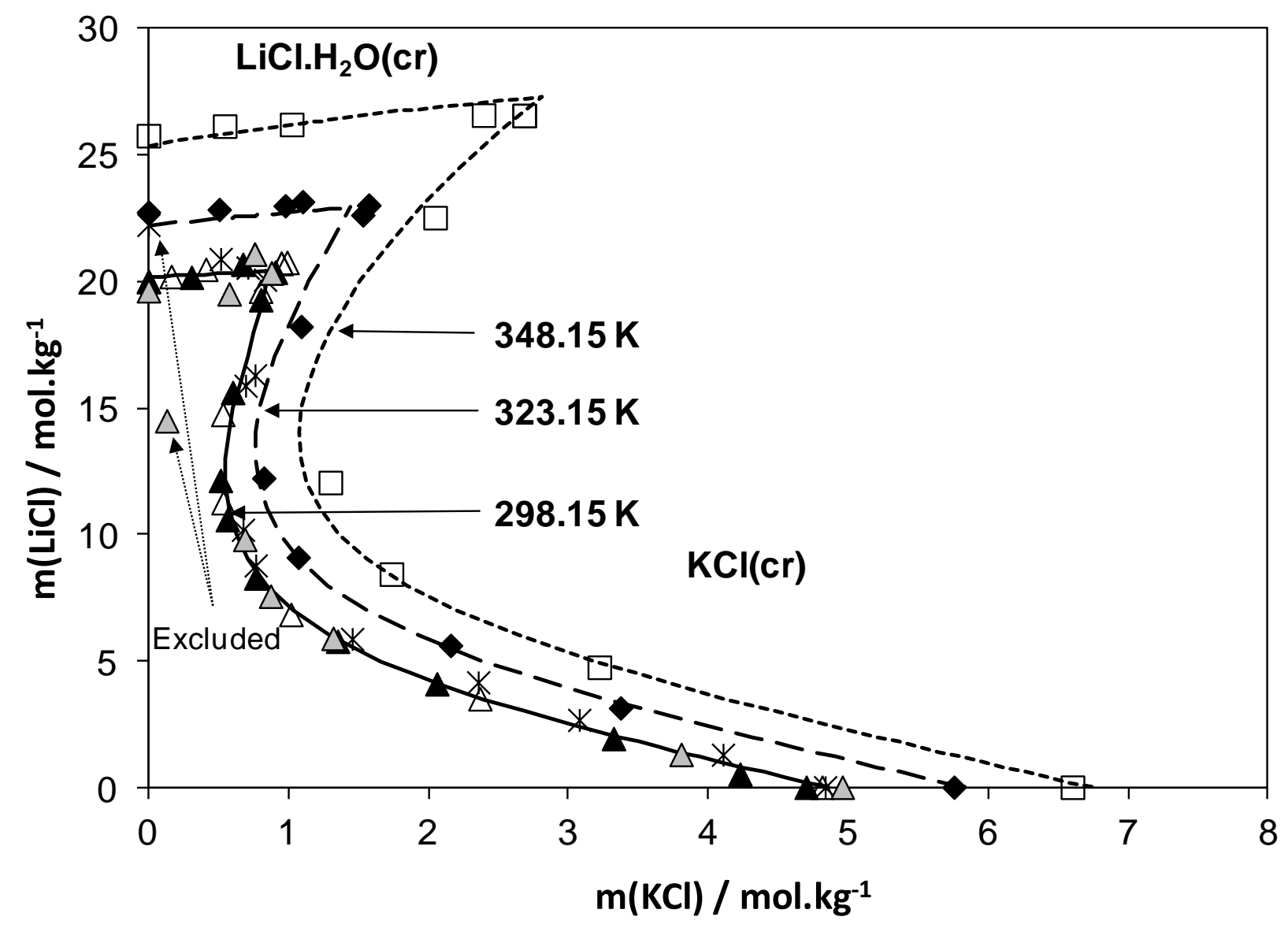

Figure $20 \mathrm{~B}$ 


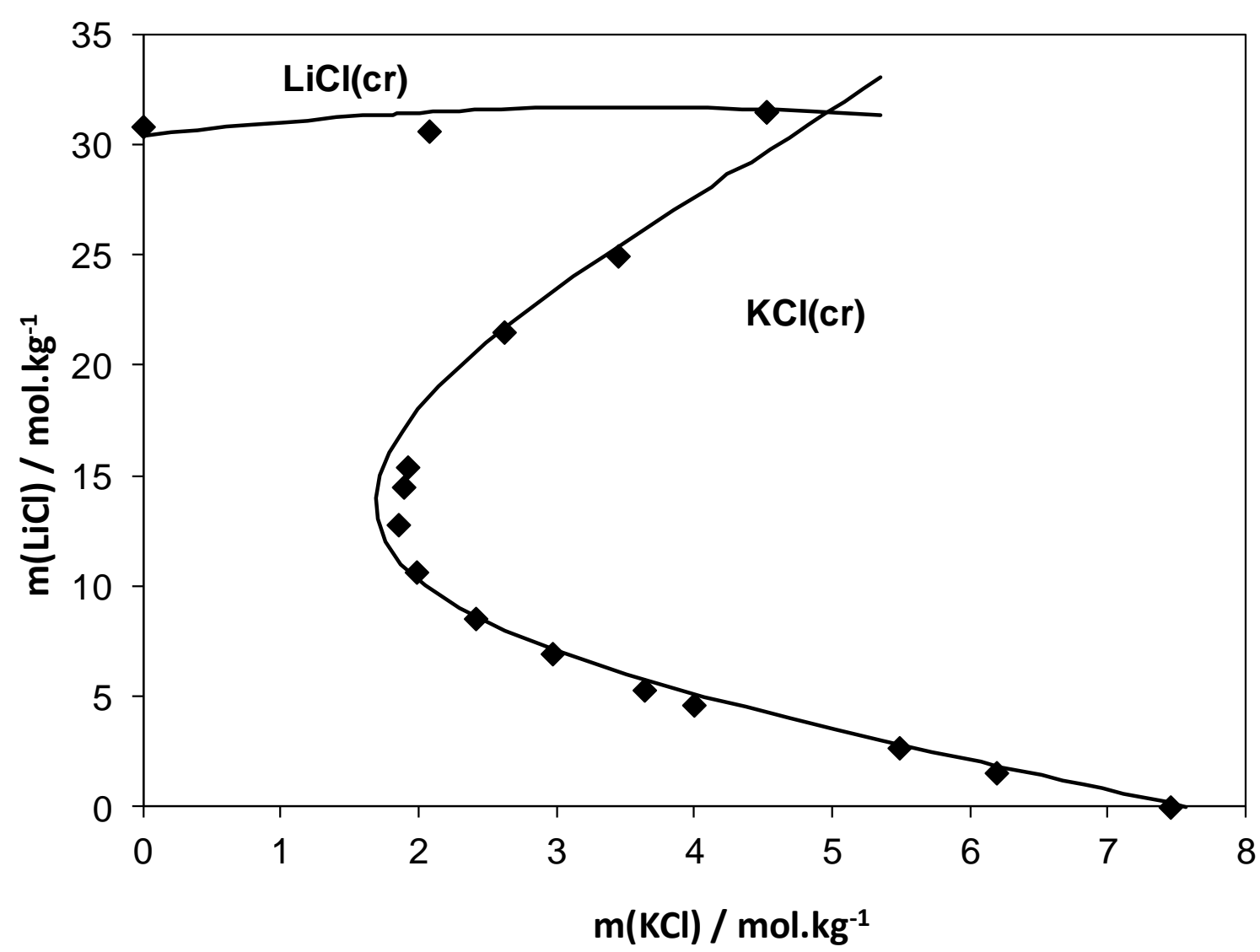

Figure $20 \mathrm{C}$ 


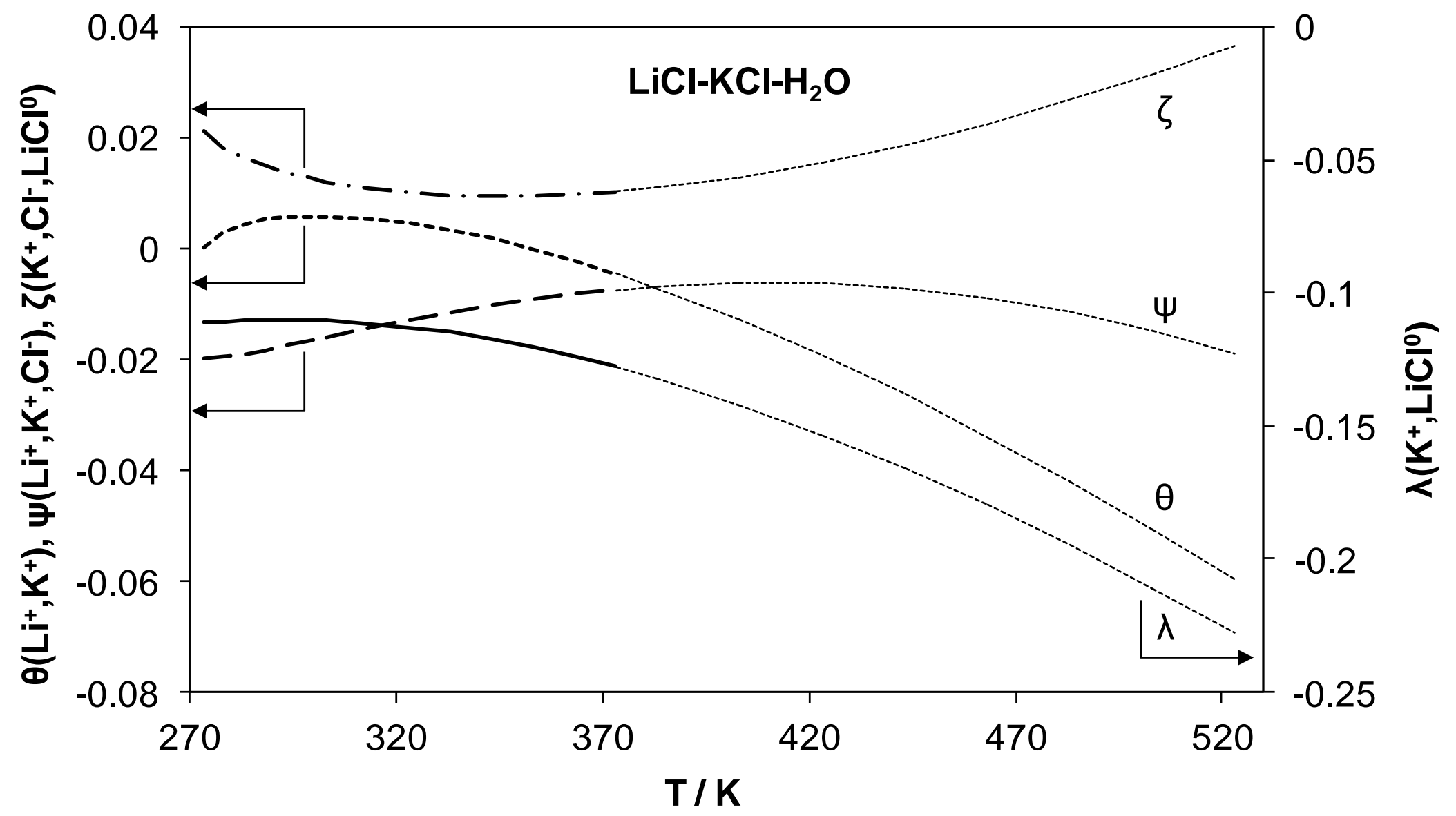

Figure 21 


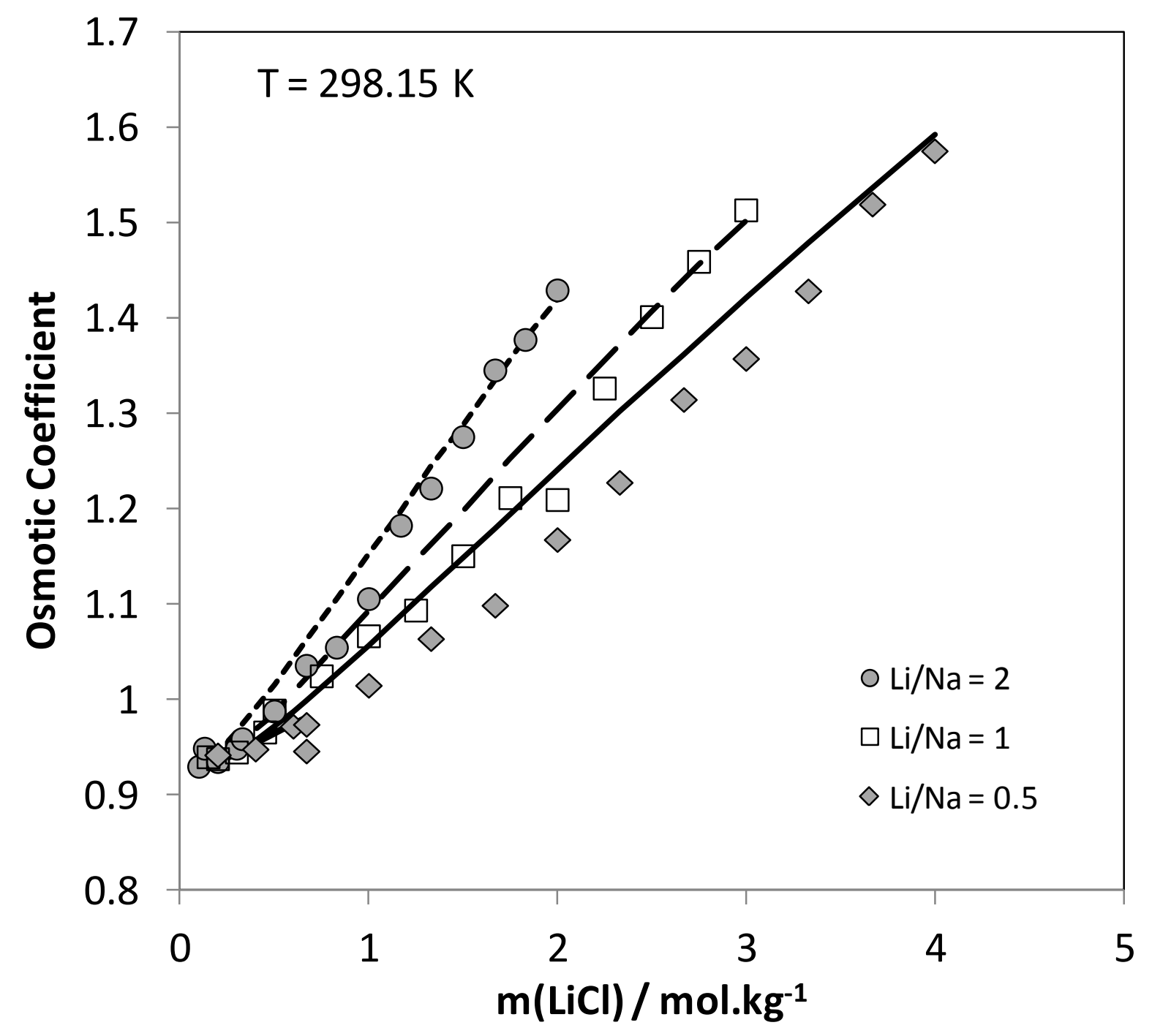

Figure 22 


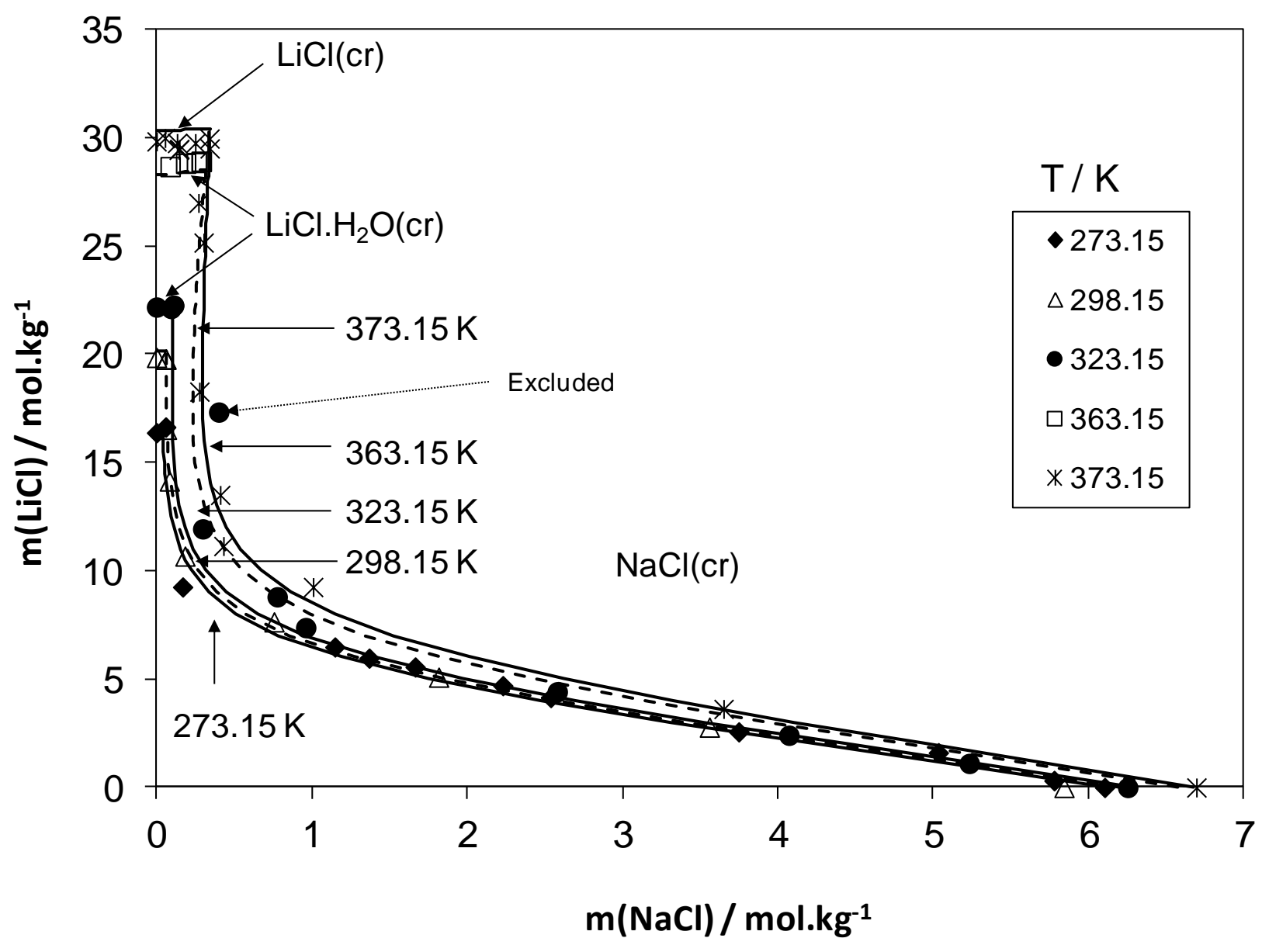

Figure $23 \mathrm{~A}$ 


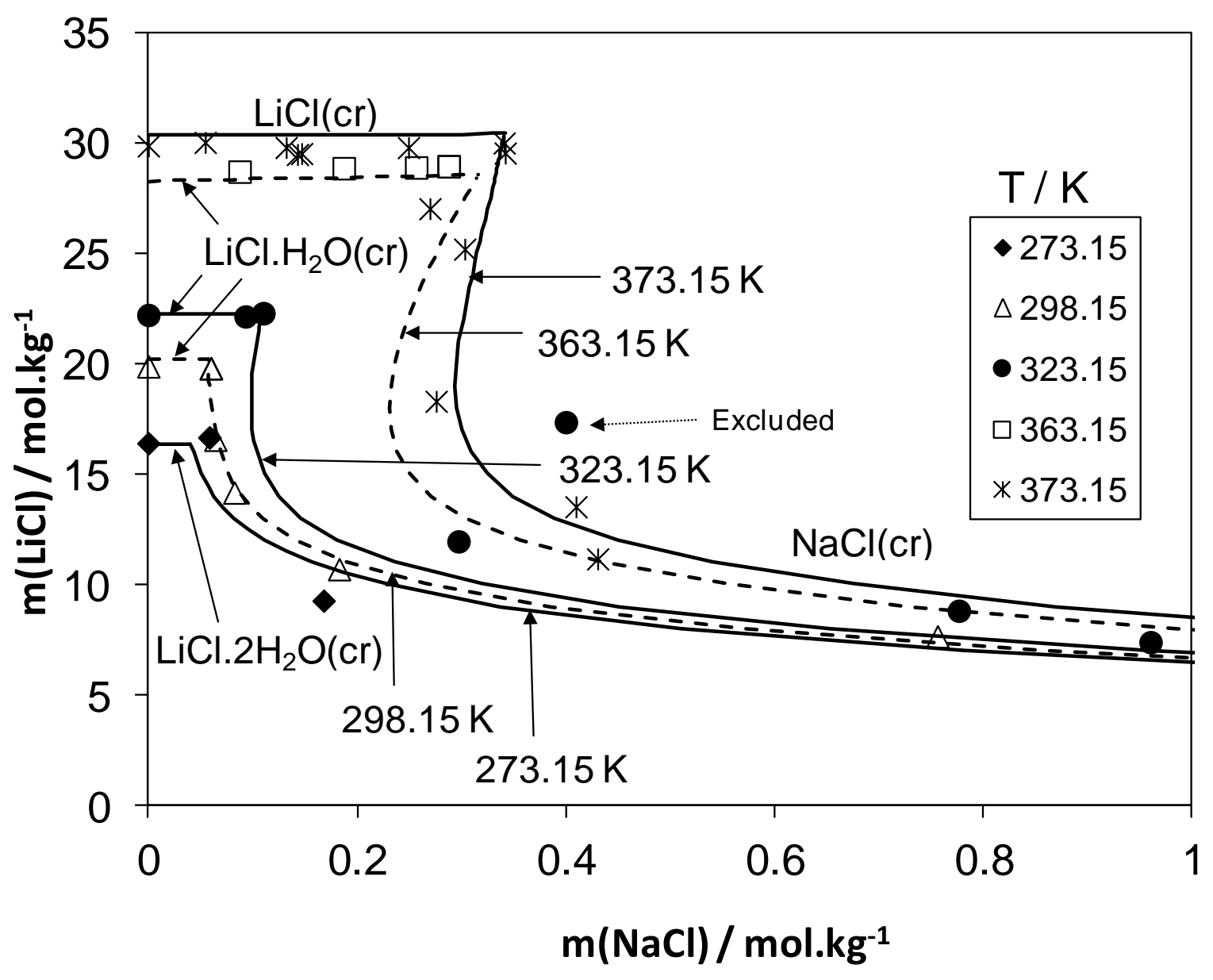

Figure $23 \mathrm{~B}$ 


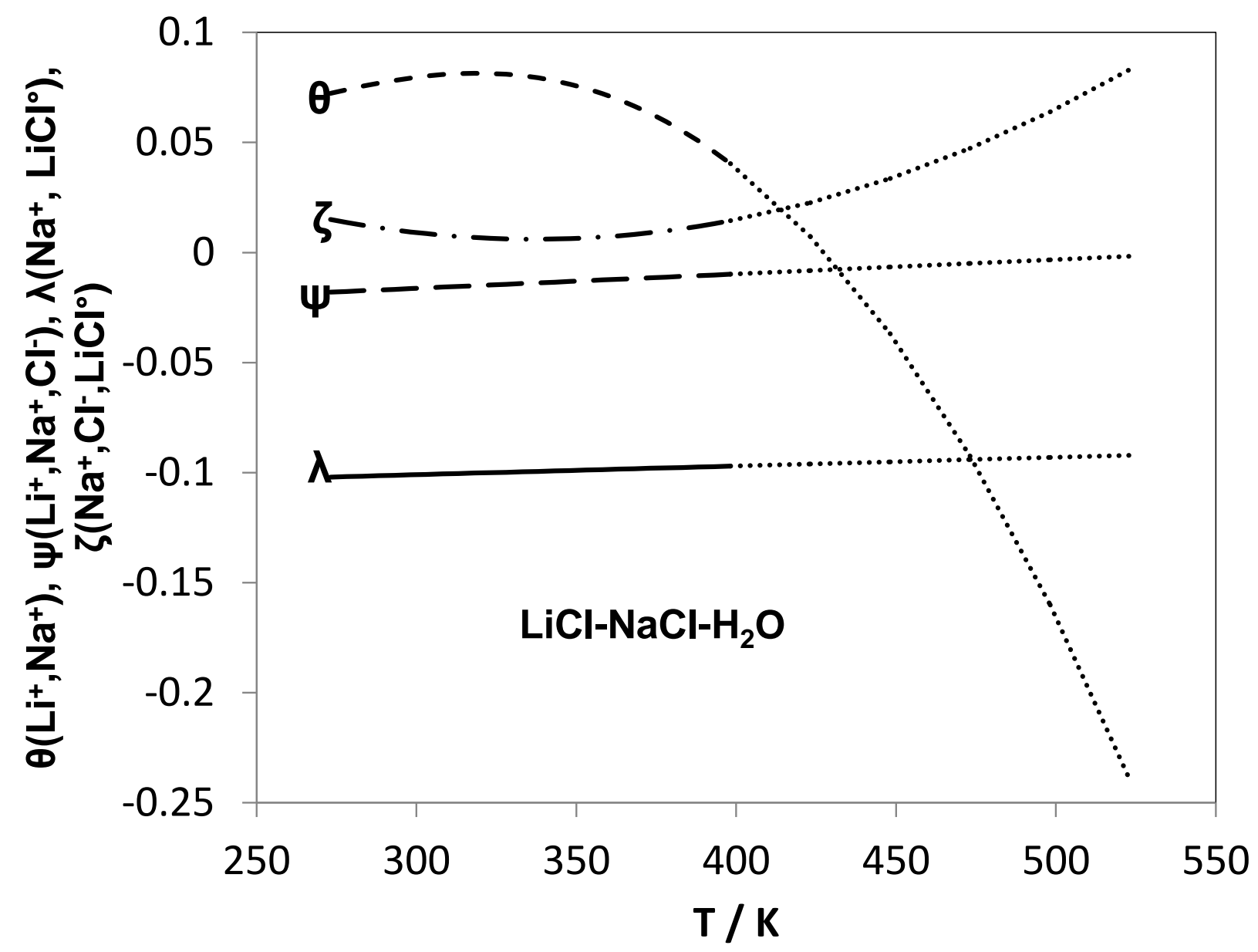

Figure 24 


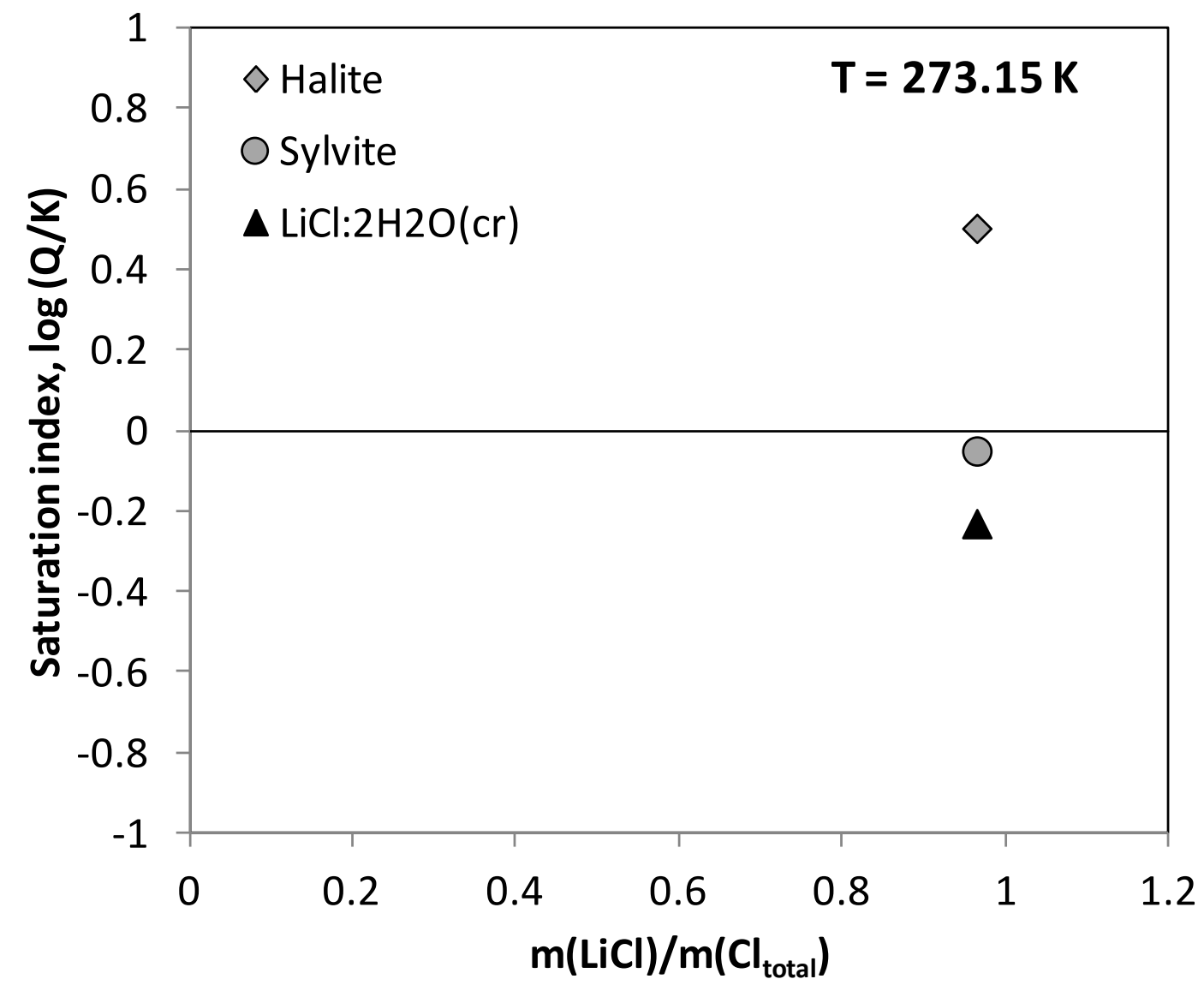

Figure $25 \mathrm{~A}$ 


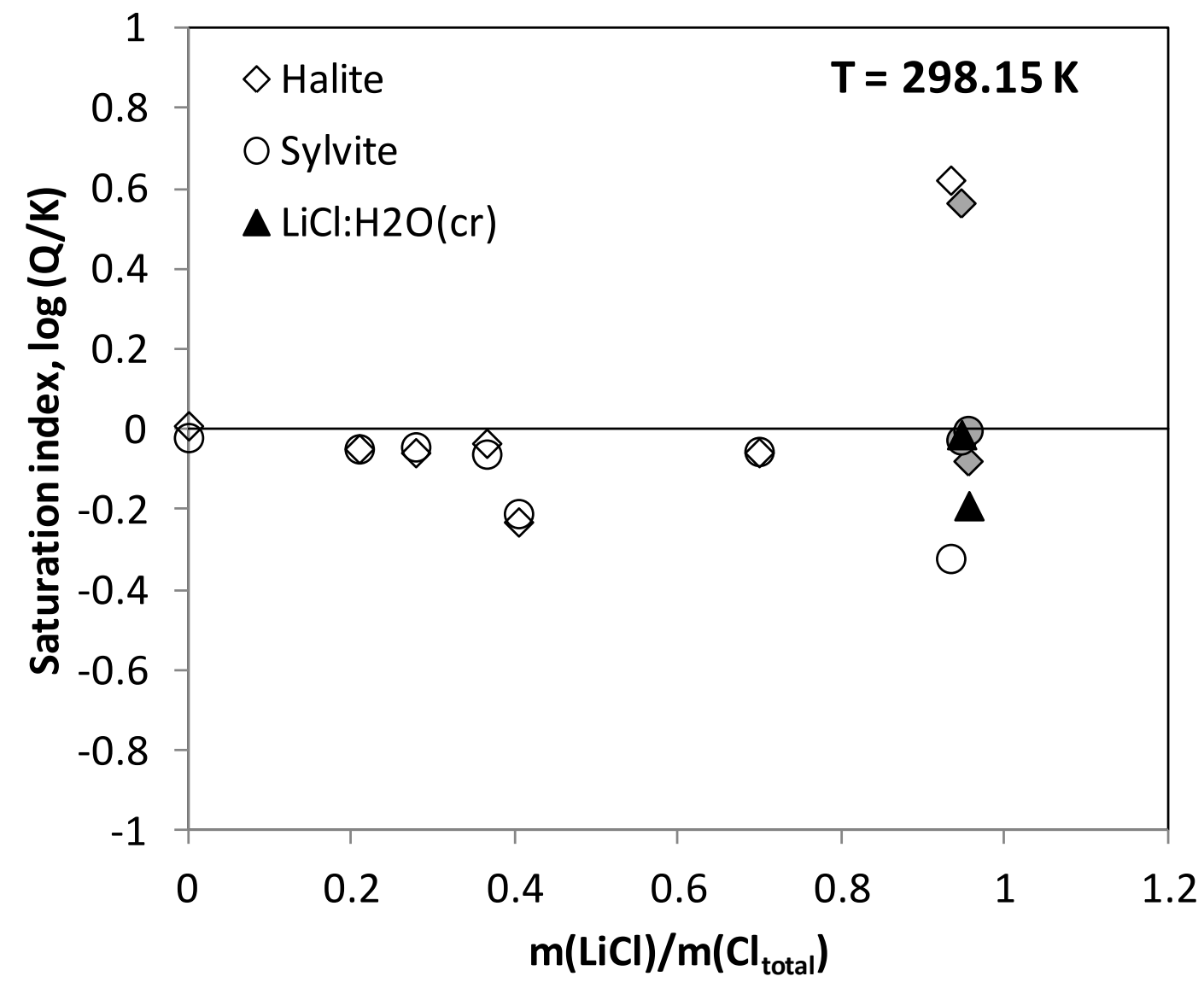

Figure 25 B 


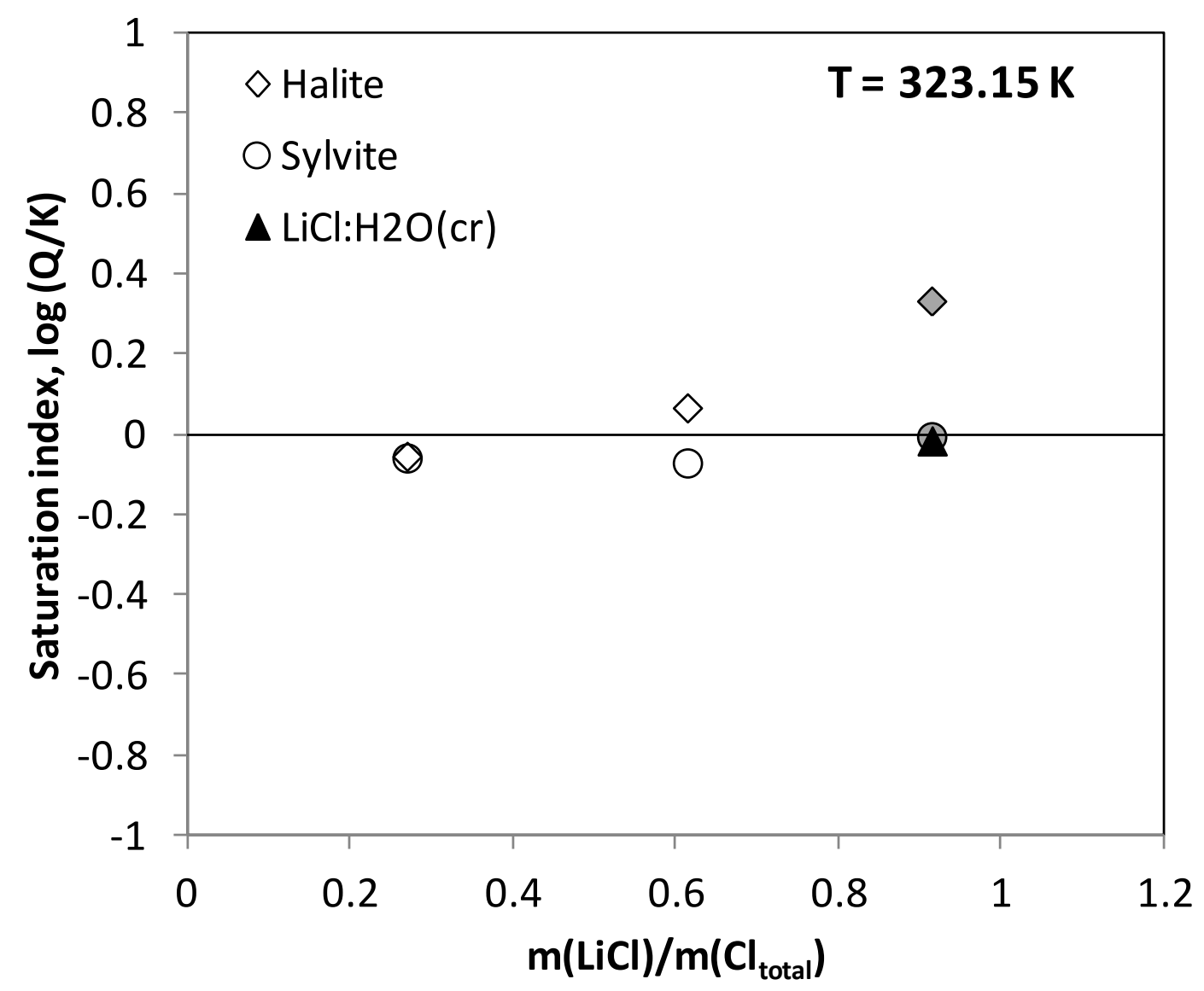

Figure $25 \mathrm{C}$ 


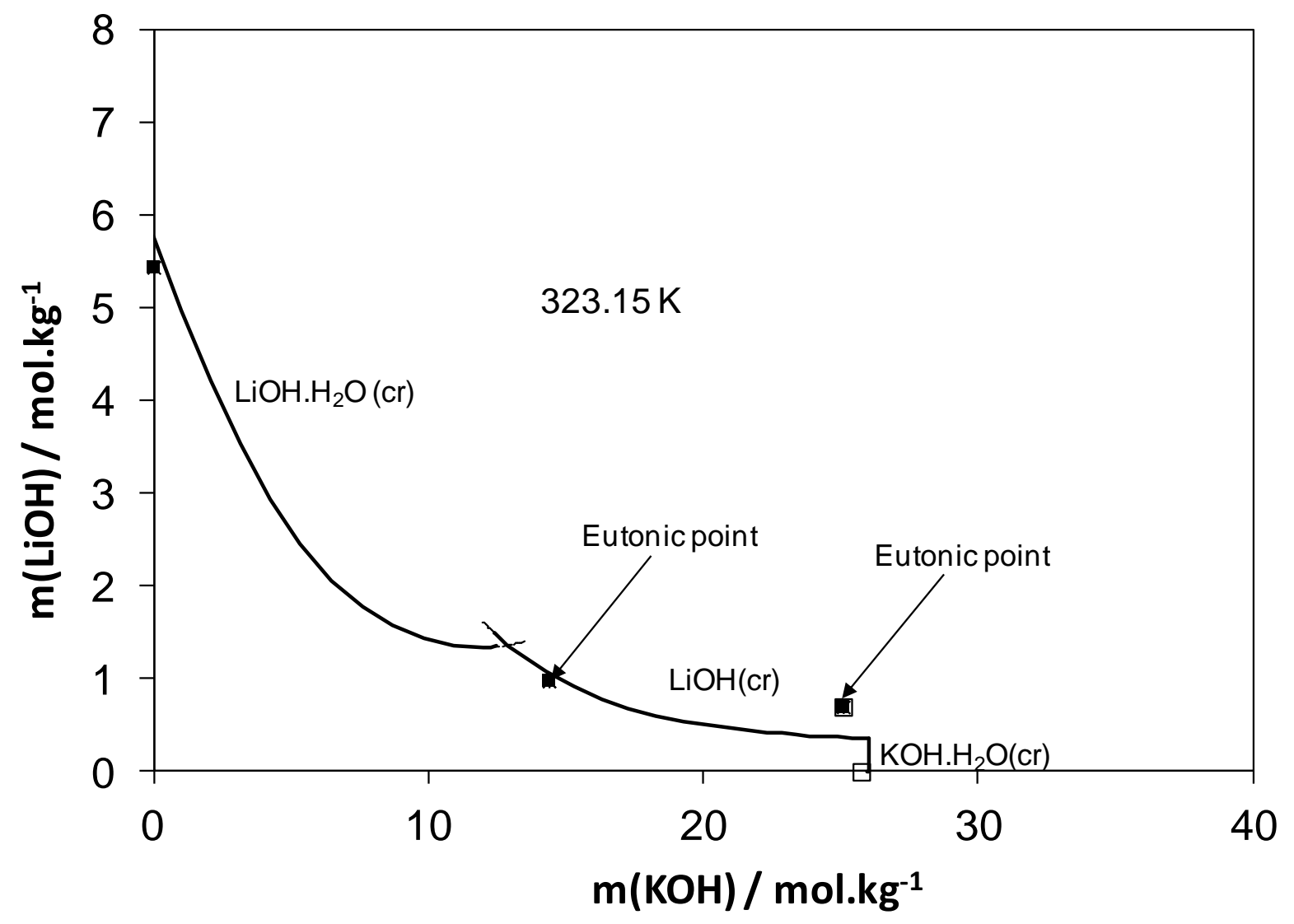

Figure $26 \mathrm{~A}$ 


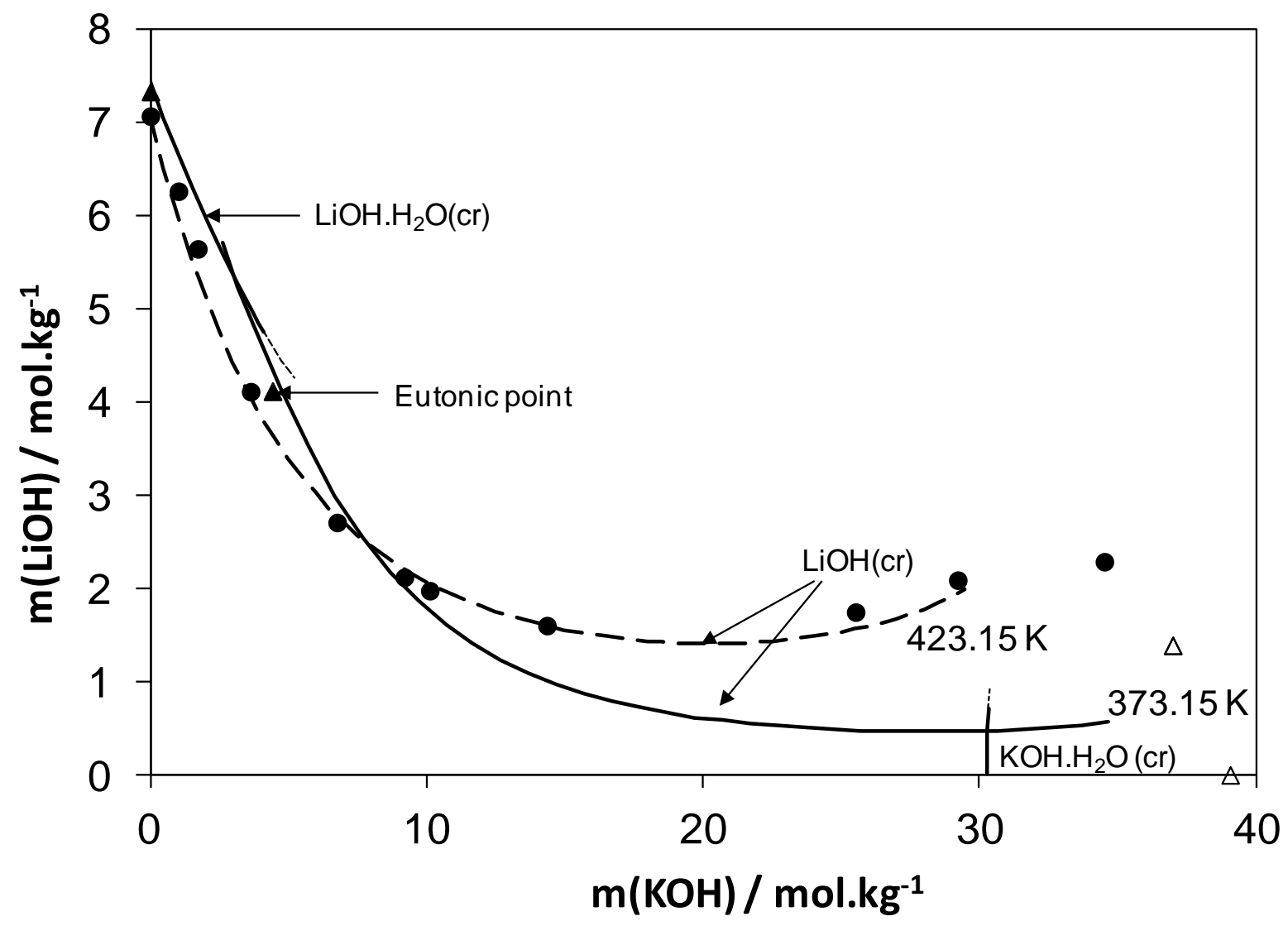

Figure 26 B 


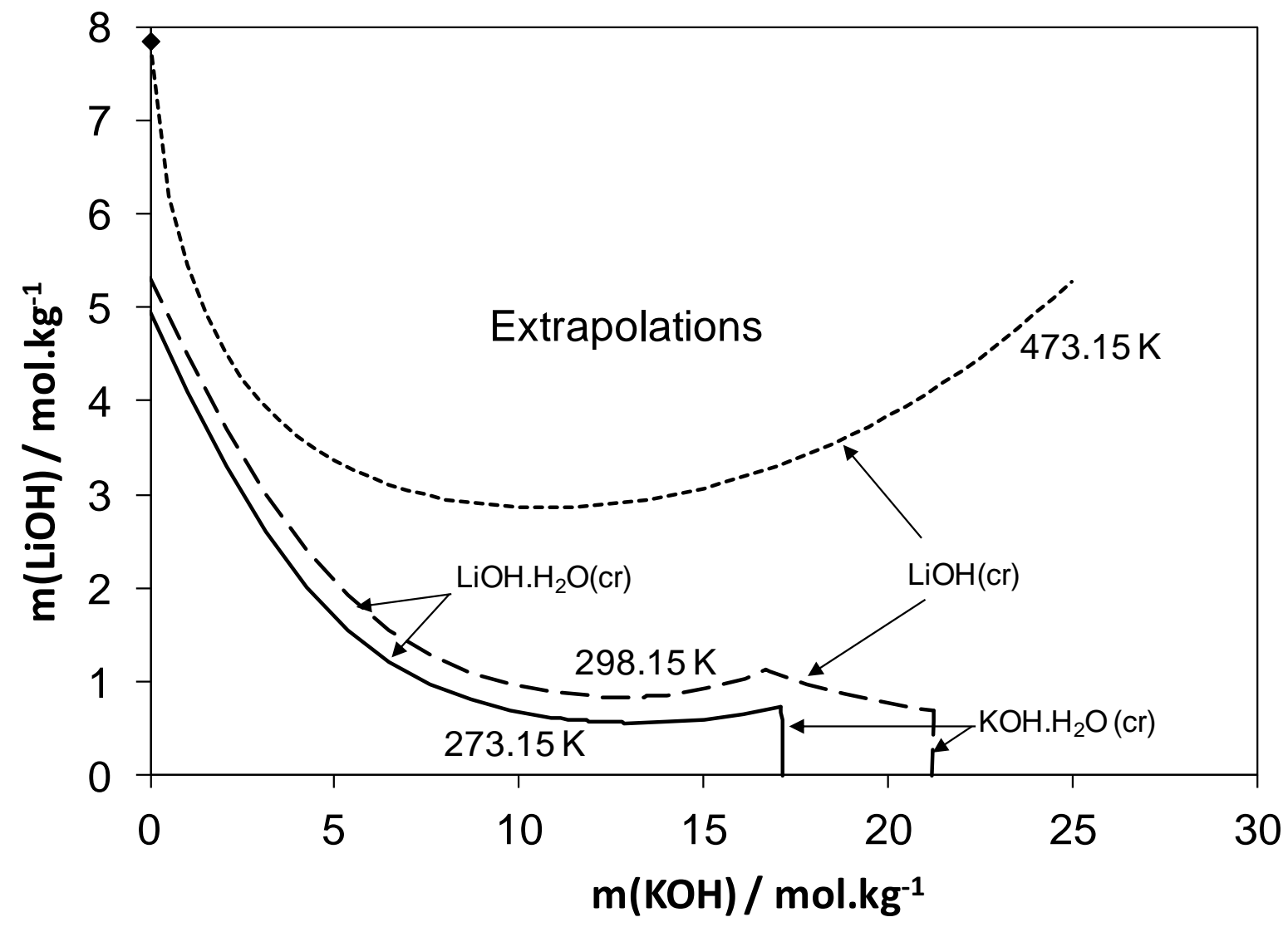

Figure $26 \mathrm{C}$ 


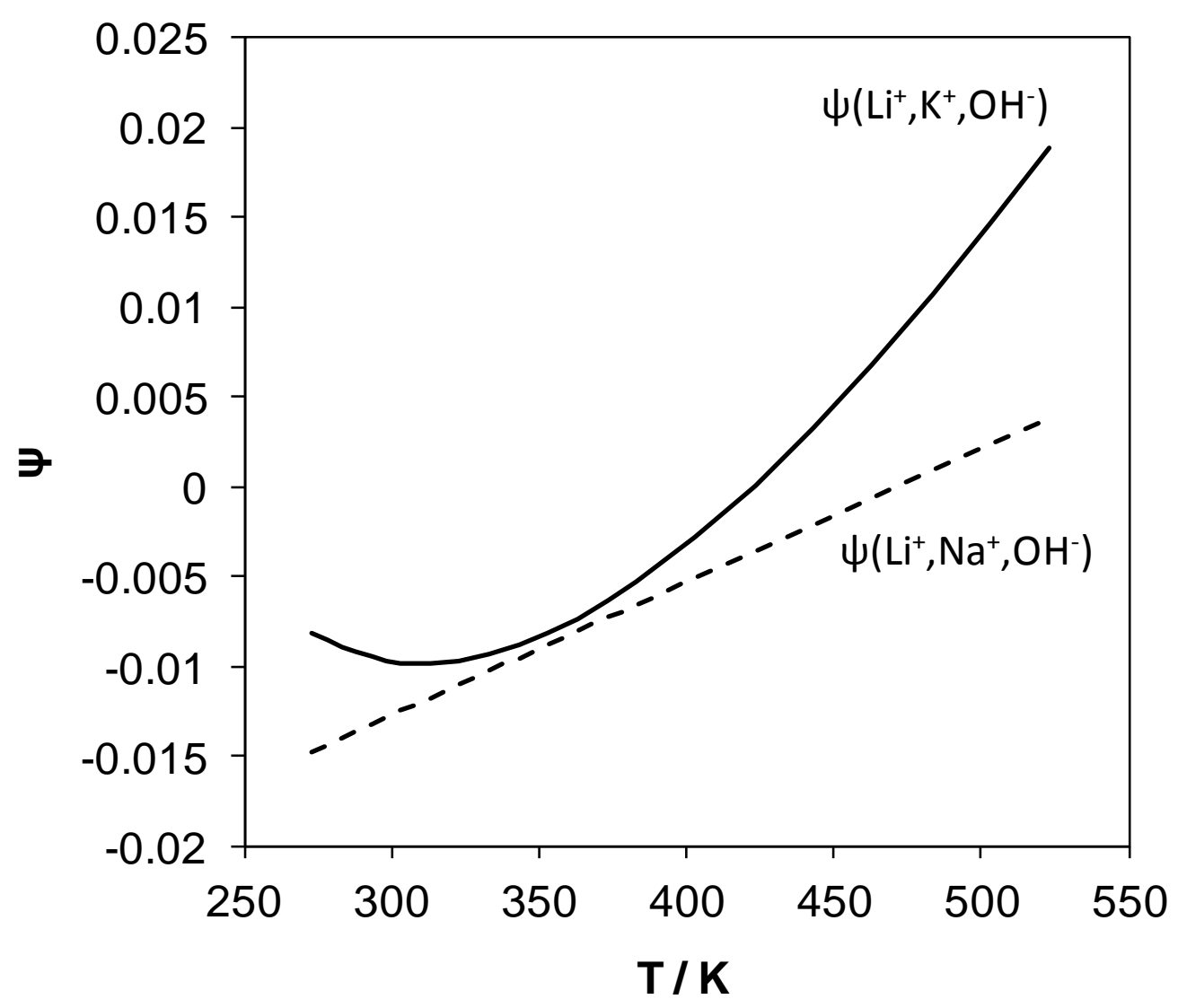

Figure 27 


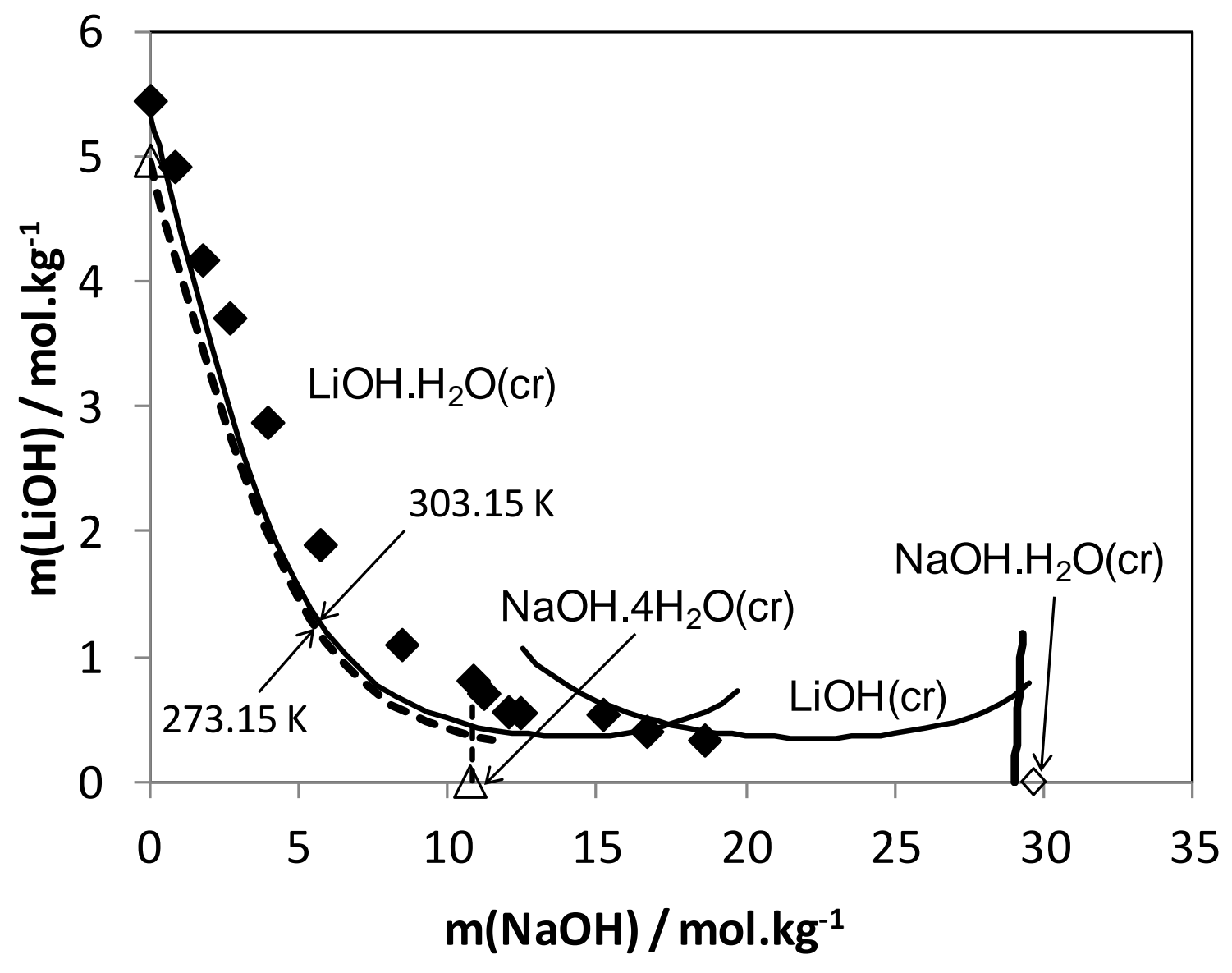

Figure $28 \mathrm{~A}$ 


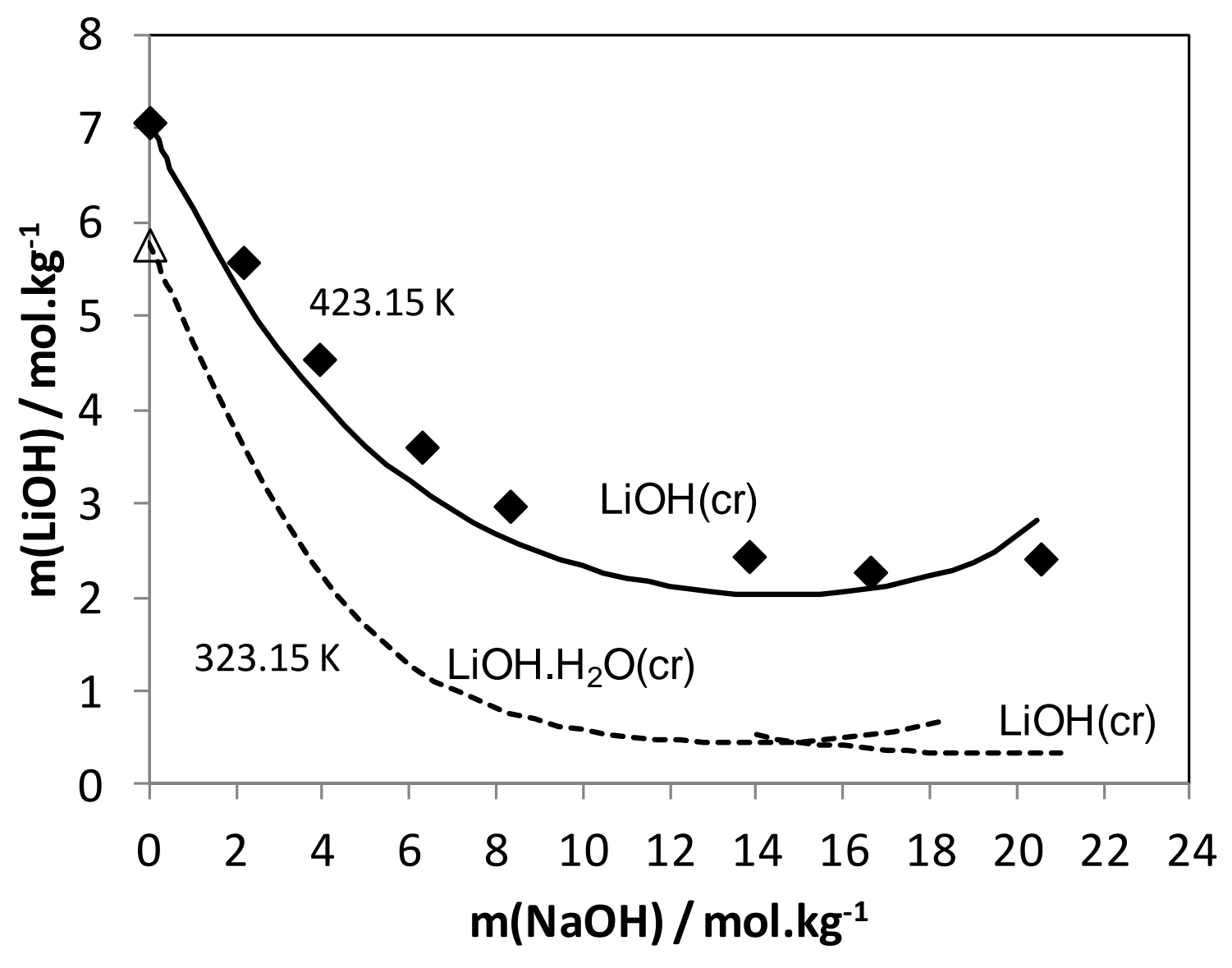

Figure $28 \mathrm{~B}$ 